TWO U.S. ELECTIONS: 1960 AND 2000.

\title{
A COMPARISON OF CHARACTER.
}

\section{SIMON JAMES POWER}

A thesis submitted to the Victoria University of Wellington in fulfilment of the requirements for the degree of Master of Arts in Political Science.

Victoria University of Wellington 


\section{TABLE OF CONTENTS}

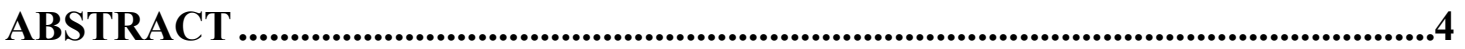

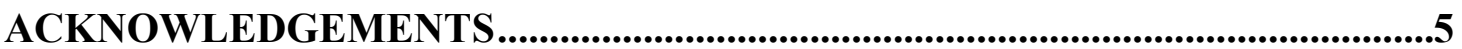

CHAPTER ONE:

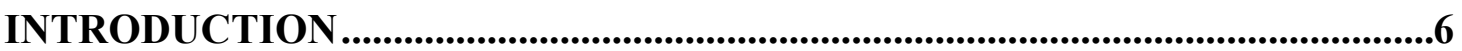

CHAPTER TWO:

A CONCEPTUAL FRAMEWORK AND LITERATURE REVIEW .....................8

CHAPTER THREE:

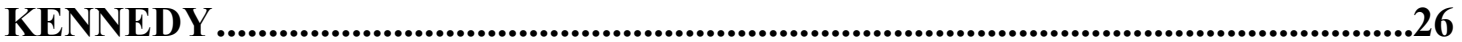

CHAPTER FOUR:

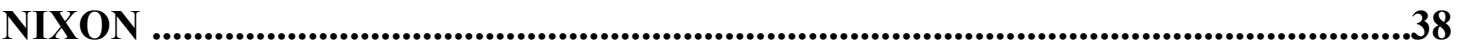

CHAPTER FIVE:

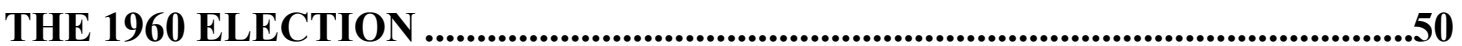

CHAPTER SIX:

GORE

CHAPTER SEVEN:

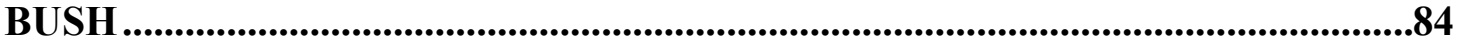

CHAPTER EIGHT:

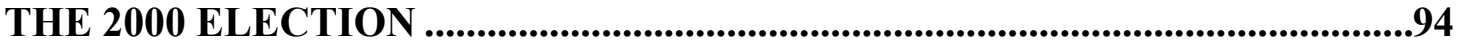


CHAPTER NINE:

CONCLUDING COMPARISONS: TWO ELECTIONS, FOUR CANDIDATES AND THE IMPORTANCE OF 'AUTHENTICITY' 114

BIBLIOGRAPHY 118 
The United States presidential election in 2000 was one of the closest in history. In 1960 , the winner of the popular vote in that presidential election won by the narrowest of margins. Forty years separated the two results, and both involved a sitting Vice President losing to a relative newcomer.

This study sets out the backgrounds of each of the four presidential candidates who competed in 1960 and 2000 and aims to understand the character of each by examining the influences on their lives and the development of their defining character traits. The second aim is to understand the authentic nature of their character by applying several theoretical frameworks to each of them. The application of these theoretical models is done in the context of the outcomes of the 1960 and 2000 elections and, in particular, the losing candidates' reactions to those results. It is at this most crucial moment that decision-making best reflects whether the candidate's reaction is authentic in the context of his character development. 


\section{ACKNOWLEDGEMENTS}

This thesis would not have been possible without the influence of certain people. For the guidance and oversight of my supervisor, Professor Stephen Levine, I am truly grateful. His depth of knowledge and accompanying stories, were remarkable to say the least. His sense of humour is first class.

To his colleagues at Victoria University who have always encouraged me, especially Professor Margaret Clark - thank you.

My interest in U.S. politics was honed at Victoria University between 1988 and 1993, but first started in 1985 when I was introduced to the topic by my history teacher Mrs Robertson. Her fine teaching has maintained my interest in this subject ever since.

Most importantly I would like to thank my family, Lisa, Sam, and Harry who put up with me locking myself away from time to time to write this thesis. 


\section{CHAPTER ONE:}

\section{INTRODUCTION}

The privilege of a lifetime is to become who you truly are.

Carl Gustav Jung

The presidential elections of 1960 and 2000 were two of the closest elections in U.S. history. This study will compare these two elections using the character of the four main contenders as the primary point of contrast. For the 1960 election those candidates were John F. Kennedy and Richard M. Nixon and for the 2000 election they were Al Gore and George W. Bush.

The backgrounds and experiences of each candidate will be examined and will include the events and tragedies each candidate endured in their early years. A critical point of comparison will be an overview of decisions each made in their formative years to define whether decisions subsequently made (leading up to and after the elections in question) were consistent, and therefore, authentic.

Surprisingly, previous behaviour and decision-making patterns may not prove great predictors of the crucial question under consideration: Whether the backgrounds and character of the four candidates provide a useful tool in measuring their responses to the outcome of a very close presidential election - in particular, whether the decision of the loser of each of those elections to challenge (or not) the outcome of that election is consistent with a display of authentic character.

Early parts of this thesis will focus on the four contenders and their past influences and crucial moments of decision-making and will then be overlaid with a conceptual framework (set out in chapter 2). Interesting trends emerge showing similarities between the formative years of each candidate's character - such as the loss of a sibling - while stark differences also emerge - such as the lack of means available to 
Nixon, as opposed to the other three candidates. In any event, a character assessment of each of the four contenders provides a fascinating insight into the level of determination, preparation and precise execution required to make it to the highest level in U.S. politics.

An essential assessment of any politician's character is a task that could lend itself to the writing of several studies on the theoretical aspects of such insights alone, and this study does not purport to be exhaustive in analysing each of the candidates. What the thesis does set out to do is to analyse the crucial decisions they made and the impact of matters beyond their control as they affected character development. That essential character is then used as a tool to gauge and measure the response each had to the outcome of the two elections under consideration.

In essence, the thesis comes ultimately to focus on the following question: was the decision of Nixon to not challenge the result of the 1960 election, and the decision of Gore to challenge the result in 2000 , consistent with their character development and therefore authentic in nature? 


\section{CHAPTER TWO:}

\section{A CONCEPTUAL FRAMEWORK AND LITERATURE REVIEW}

The primary methodology chosen for this thesis is an analysis of the character of the four contenders in two of the closest presidential elections in U.S. history. Those candidates have their backgrounds set out in chapters 3, 4, 6 and 7. These chapters are not an attempt to detail every aspect of their lives, but rather to provide a number of instances where their responses and actions provide an insight into their character.

Such instances provide an understanding as to whether the decision-making undertaken by the contenders is consistent (and therefore authentic) in matching with their later decisions. Various situational paradigms present themselves in the lives of each case study, but one particularly interesting aspect is the death of a sibling in each contender's life. Whether the psychological impact of this tragedy is enough reason to primarily explain the drive exhibited by each candidate remains an area for further examination.

In many respects the study of character has become indistinguishable from leadership theory. This chapter will include a literature review of the relevant works dealing with authenticity and character and an early acknowledgment that this literature continues to grow. While not exhaustive in scope, it will provide a theoretical framework for comparison in chapters 5,8 and 9 .

The relevant literature in this area is broad and constantly developing. Authenticity as a measure (or method of weighing) leadership has to some extent emerged from the ashes of the more binary distinction of leadership involving transactional and transformational leadership theory. ${ }^{1}$ Authenticity must be more than “... a sense that a

\footnotetext{
${ }^{1}$ Kennedy, Fiona and Kolb, Darl G. (2016). The Alchemy of Authenticity: Lessons from the 2016 US Presidential Campaign. Organizational Dynamics, 45, p. 317.
} 
candidate means what he says and will do what he intends to do when he gets into office."2

There is an extensive body of work regarding candidate centred politics, moving from party based machinery as the sole determinant of voting success. ${ }^{3}$ Wattenberg, although not dismissing performance as a key determiner of electoral success, notes the significance of the emergence of a candidate's importance in the context of voting patterns. ${ }^{4}$ Miller and Shanks suggest “... whether or not current presidential politics ... is best characterized as candidate-centered is less important than ... the role of voter evaluations of the candidates ... receiving more systemic attention." ${ }^{5}$ This work followed the research of candidate attributes “... first marked by The Voter Decides in 1954. The American Voter in 1960 continued that measurement tradition ... of personality exhibited ... by the candidates." 6 This work in turn foreshadowed the emergence of a body of work on candidate traits and their measurement. Miller and Shanks note that “... Carolyn Funk ... summarized, ... based on NES data[,] ... the identification of nine 'traits' of political leadership that presumably measured four "dimensions"." These dimensions were competence, effectiveness, integrity and empathy. ${ }^{8}$

\footnotetext{
${ }^{2}$ Ibid, p. 316.

${ }^{3}$ King, Anthony. (ed.). (2002). Leaders' Personalities and the Outcomes of Democratic Elections. New York: Oxford University Press.

${ }^{4}$ Wattenberg, Martin P. (1991). The Rise of Candidate-Centered Politics - Presidential Elections of the 1980’s. Cambridge: Harvard University Press, pp. 34-35.

${ }^{5}$ Miller, Warren E. and Shanks, J. Merrill. (1996). The New American Voter. Cambridge: Harvard University Press, p. 414.

6 Ibid, p. 415. For further detail see also: Nimmo, Dan and Savage, Robert L. (1976). Candidates and Their Images: Concepts, Methods and Findings. Santa Monica: Goodyear Publishing.

${ }^{7}$ Ibid, p. 416.

${ }^{8}$ Ibid.
} 
The notion of "trait ownership", 9 and the concept that political parties own issues but candidates own traits, can present the opposing view to authentic character delivering electoral success. It is worth noting that Hayes suggests "trait ownership" can be trespassed on by opponents. ${ }^{10}$ In particular: "If voters expect a party's candidates to be representative of certain traits but not others, a candidate may gain advantage if he can successfully 'trespass' on his opponent's trait territory."11 Or put another way, "Trait ownership provides a baseline for expectations, and trait trespassing can yield an electoral benefit." 12

This thesis is focused on the authenticity of choices made by candidates at the point when an election is lost. That display of authenticity may require more than a mere consistency of trait exhibition, or is authenticity merely a subset of a well defined recognisable series of basic trait dimensions? Greene asserts that "Miller, Wattenberg, and Malanchuk (1986) and Conover and Feldman (1986) similarly conclude that schematic assessments of presidential character traits play a central role in the evaluation of presidential candidates and ultimately vote choice."13 Holian and Prysby refer to the work of Donald Kinder's 1986 study “... which analysed a large number of character traits and found they could (again) be reduced to four basic trait dimensions: leadership, competence, integrity and empathy." 14 Other scholarly work has refined

\footnotetext{
${ }^{9}$ Hayes, Danny. (2005). Candidate Qualities through a Partisan Lens: A Theory of Trait Ownership. American Journal of Political Science, 49(4), p. 908.

${ }^{10}$ Ibid, p. 909.

${ }^{11}$ Ibid.

${ }^{12}$ Ibid.

${ }^{13}$ Greene, Steven. (2001). The Role of Character Assessments in Presidential Approval. American Politics Research, 29(2), p. 198.

14 Holian, David B. and Prysby, Charles L. (2015). Candidate Character Traits in Presidential Elections. New York: Routledge, pp. 22-23.
} 
(and in some cases merged) these dimensions ${ }^{15}$ but Holian and Prysby look to insert authenticity into a character trait category:

\begin{abstract}
“... authenticity can mean integrity; an authentic candidate is straightforward and honest about where he or she stands, not a phony person who says what voters want to hear or who tries to mislead them. However, authenticity can also mean something else, as pundits sometimes use elitism and authenticity as antonyms. That is, an authentic candidate is someone who most voters can relate to, ... of being 'down to earth'... not an elitist ... [a]uthentic candidates are the kind of people that a voter would enjoy being with. Thus authenticity sometimes is used to refer to aspects of integrity, other times to refer to aspects of elitism, and sometimes it is unclear exactly what the term means (emphasis added)." 16
\end{abstract}

Attempting to further refine authenticity can be challenging as "...[i]t is difficult to describe ... in any neat definition or set of characteristics." ${ }^{" 17}$ Bhindi and Duignan conclude by defining authenticity as being “... intrinsically ethical. It involves an authentic view of self mediated by significant values (ethical standards) and meaningful relationships" in which "[a]uthentic leaders attempt to do what is right regardless of the consequences ... often at a cost to themselves." 18 A further definition of the components of authentic leadership “... [has] its roots in Greek philosophy ('To thine own self be true') ... [being] unencumbered by others' expectations for them $\ldots " .{ }^{19}$ The term is further refined by noting that “... authenticity does not involve any explicit consideration of 'others'; instead, the authentic self is seen as 'existing wholly by the laws of its own being' ..." ${ }^{20}$ Avolio and Gardner further note: “... authenticity [is] not an either/or condition, i.e., people are never entirely authentic or inauthentic. Instead, they can more accurately be described as achieving levels of authenticity."21

${ }^{15}$ Including: Funk, Carolyn L. (1999). Bringing the Candidate into the Models of Candidate Evaluation. Journal of Politics 61(3), pp. 700-720; Conover, Pamela J. (1981). Political Cues and the Perceptions of Candidates. American Politics Quarterly 9(4), pp. 427-448; and Markus, Gregory B. (1982). Political Attitudes during an Election Year. American Political Science Review 76(3), pp. 538-560.

16 Holian and Prysby, Candidate Character Traits in Presidential Elections, pp. 30-31.

17 Bhindi, Narottam and Duignan, Patrick. (1997). Leadership for a New Century. Authenticity, Intentionality and Sensibility. Educational Management \& Administration, 25(2), p. 123.

${ }^{18}$ Ibid, p. 130.

19 Avolio, Bruce J. and Gardner, William L. (2005). Authentic leadership development: Getting to the root of positive forms of leadership. The Leadership Quarterly, 16(3), pp. 319-320.

${ }^{20}$ Ibid, p. 320.

21 Ibid. 
Referencing the 1980 presidential election, Markus concludes: "It was found that beliefs about candidate traits could be organised into two primary dimensions, beliefs about the personal competence of a candidate and beliefs about his personal integrity." 22 The notion of integrity features throughout the literature:

“... the essence of authenticity is to know, accept, and remain true to one's self ... it is best to recognise that authenticity exists on a continuum and that the more people remain true to their core values, identities, preferences and emotions, the more authentic they become." 23

The focus of this thesis is on the element of integrity as it relates to authenticity and a consistency of decision-making behaviour and actions. Integrity matters because it implies a consistency “... between one's outward and inner life and a consistent presentation of one's self from group to group. It also implies the avoidance of decisions based on expedience, that is, just for temporary personal or political benefit." 24

But the notion of authentic leadership as a definable trait or quality continues to evolve. ${ }^{25}$ Kennedy and Kolb examine the work of Avolio ${ }^{26}$ when defining authentic leadership and regard it as positioning “... authenticity well beyond referring to those who had deep knowledge of themselves. Authenticity came to imply a range of attributes including [the] assertion that authenticity was connected to hope, resilience

\footnotetext{
22 Markus, Political Attitudes during an Election Year, p. 559.

23 Avolio, Bruce J., Gardner, William L., Walumbwa, Fred O., Luthans, Fred and May, Douglas R. (2004). Unlocking the Mask: A Look at the Process by which Authentic Leaders Impact Follower Attitudes and Behaviors. The Leadership Quarterly, 15, p. 802.

${ }^{24}$ Pfiffner, James P. (2004). The Character Factor - How We Judge America's Presidents. Texas : A\&M University Press, p. 13.

25 Winter, David G. (2005). Things I've Learned About Personality From Studying Political Leaders at a Distance. Journal of Personality, 73(3), pp. 557-584. Here Winter notes on p. 567: “Conceptually, traits involve consistency of publicly observable behavior." See also: Kilburn, H. Whitt. (2005). Does the Candidate Really Matter? American Politics Research, 33(3), pp. 335-356.

${ }^{26}$ Avolio et al. Unlocking the Mask, pp. 315-338.
} 
and high moral character." ${ }^{27}$ Authenticity is not synonymous with "sincerity" and the literature continues to debate whether its characterisation is entirely self-referenced and self-contained, so that there is little flexibility or adaptive qualities when interactions with others occur. However, for the purposes of this study it is useful to ground a definition in the notion that "[a]uthentic leadership has become idealistically broad, but remains focused on being true to one's self - a self that is distinct and entirely independent of another's viewpoint." 28 Kennedy and Kolb do not allow the definition to remain static. They add: "[w]e suggest that the pursuit of detached selfactualization $^{29}$ ignores the fundamentally social and relational dynamic of leadership, including authentic leadership."30

So, circumstances matter. Character (particularly authenticity) is more than traits, more than an inward-looking consistency of approach; it is situational. It is also relational in the sense that "... authenticity emanates from an alchemy between leaders and followers ..." 31

Before authenticity can be assessed, due consideration should be given to the development of character. Pfiffner offers the view that traits essential to the integrity of character include: truthfulness, sexual fidelity, consistency and promise keeping. ${ }^{32}$ The past experiences of the candidate matter, and the consistency of approach and reaction exhibited later in life go directly to authenticity. "Thus the examination of early experiences, challenges confronted, and emotional relationships are part of the complex web that makes up a person's unique character." 33

\footnotetext{
${ }^{27}$ Kennedy and Kolb, The Alchemy of Authenticity, p. 317.

28 Ibid, p. 318.

${ }^{29}$ Self actualisation includes the notion of "a fuller knowledge of, and acceptance of, the person's intrinsic nature." See: https://scottjeffrey.com/self-actualisation as an introduction to Abraham Maslow's findings.

${ }^{30}$ Kennedy and Kolb, The Alchemy of Authenticity, p. 318.

${ }^{31}$ Ibid, p. 320.

${ }^{32}$ Pfiffner, The Character Factor, p. 3.

${ }^{33}$ Ibid, p. 16.
} 
Character is not the same as personality; "[ $\mathrm{t}]$ he point is not to see the individual as a certain type of person, but rather to understand the multiplicity of factors that make up the unique individual within that person's historical context." 34 This approach to character analysis is further supported by the approach taken by Barber, who defines "character" as "... from the Greek word for engraving; in one sense it is what life has marked into a man's being. As used here, character is the way the President orients himself toward life - not for the moment, but enduringly." 35

Barber offers two further layers of assessment: “...[p]residential personality is patterned. His character, world view, and style fit together in a dynamic package understandable in psychological terms.” Importantly for this thesis, he advises: “... the best way to predict a President's character, world view, and style is to see how they were put together in the first place. That happened in his early life, culminating in his first independent political success." 36 This theme is further developed by the view that both rational and emotional factors play a role in high-level decision-making and that personality as a measure of character draws its legitimacy from an analysis of tendencies. ${ }^{37}$

Style too is important, and Barber ensures that it is not confused with "stylishness". Style necessarily involves a choice for operating, including components of the use of rhetoric; close informal dealing; or study and cogitation. ${ }^{38}$ To these three elements can be added the level of management a candidate, politician or president wishes to employ. Gardner adds context to this approach: "Most managers exhibit some

\footnotetext{
${ }^{34}$ Ibid.

${ }^{35}$ Barber, James D. (1972). The Presidential Character - Predicting Performance in the White House. New Jersey: Prentice Hall, p. 8.

${ }^{36}$ Ibid, p. 6.

${ }^{37}$ Ibid, p. 7.

${ }^{38}$ Ibid.
} 
leadership skills, and most leaders on occasion find themselves managing. Leadership and management are not the same thing, but they overlap." 39

Yet the emphasis Gardner places on the distinction between the two is significant. $\mathrm{He}$ outlines six key areas where leader/managers distinguish themselves from managers. These include: thinking longer term; thinking about conditions external to the organisation; reaching and influencing beyond boundaries; vision and values; political skill to cope with competing interests; and, most importantly in the context of this thesis, they think in terms of renewal and personal growth. ${ }^{40}$

How a leader views the political environment beyond their own short-term gain is a key element of character, and more than just a tendency. How a problem is confronted plays an important role in predicting future behaviour, something this study examines in more detail in chapter 9.

Discussing the attributes of leadership and their interplay with character authenticity is worth examination. Gardner sets out leadership attributes in detail and links the curiosity people have with how those attributes manifest themselves in a leadership framework. They include: physical vitality and stamina; intelligence and judgment-inaction; willingness (eagerness) to accept responsibilities; task competence; understanding of followers/constituents and their needs; skill in dealing with people; need to achieve; capacity to motivate; courage, resolution, steadiness; capacity to win and hold trust; capacity to manage, decide, set priorities; confidence; ascendance, dominance, assertiveness; and adaptability, flexibility of approach. ${ }^{41}$

Each leader exhibits a mix of the attributes listed, often with some missing from their framework altogether. What drives the individual concerned to exhibit such attributes is a far more complex question. Why is it that certain individuals feel the need to reach

\footnotetext{
${ }^{39}$ Gardner, John W. (1990). On Leadership. New York: The Free Press, p. 14.

${ }^{40}$ Ibid, p. 4.

${ }^{41}$ Ibid, pp. 48-53.
} 
beyond a life that would be acceptable to almost anyone else and press on for a higher prize?

The quest for power and influence is linked to leadership psychology,

"A psychological conception of power will help us cut through some of these complexities and provide a basis for understanding the relation of power to leadership. This approach carries on the assumptions ...: that power is first of all a relationship ...; that it involves the intention or purpose of both power holder and power recipient; and hence that it is collective, not merely the behaviour of one person." 42

Burns argues the two essential ingredients for power are motive and resource, and that “... to understand the nature of leadership requires an understanding of the essence of power, as leadership is a special form of power." 43 This study uses those two essential ingredients of power - motive and resource - in a political leadership context to help determine whether decisions made reflect an individual's true character. To further deepen this theoretical framework requires the prediction of behaviour. The predictability (consistency) of decision-making and an individual's reaction to past circumstances lends itself to the view that background does matter. Although not placing an unqualified emphasis on this factor, Barber asserts the view that history and background are pivotal components when examining the character of a president or candidate: "The best way to predict a President's character, world view and style is to see how he constructed them in the first place." 44

Barber takes the view that " ... character has its main development in childhood, world view in adolescence, style in early adulthood." 45 Character does not cease to develop after the end of childhood, playing a major role in determining authenticity at later times. How a child relates to parents, siblings and school are indicators of 'defining an orientation towards experience'. These traits are finessed and built on throughout life and sometimes contradicted - but character developed at these very early stages provides the main thrust and direction according to Barber.

\footnotetext{
${ }^{42}$ Burns, James M. (1978). Leadership. New York: Harper \& Row, p. 13.

${ }^{43}$ Ibid, p. 12.

${ }^{44}$ Barber, The Presidential Character, p. 9.

${ }^{45}$ Ibid, p. 10.
} 
Burns also forms the view that early experiences are pivotal to assessing a leader's character:

"One could speculate that the common inclusive childhood experience for all ... figures was intense positive attachment to one parent coupled with some intensely negative attachment to the other or an intensely traumatic and negative youthful experience. Could it be the tension between emotional demands, the conflict engendered that must be resolved, plus uncommon talent and energy, that makes the need for power so compelling?" 46

Those early experiences and the lineage of the candidates under examination will help reference the impact of experiences on the need for and enjoyment of power.

Barber sets out four types of presidential character. The baselines for the four categories are:

1. Activity-Passivity: How much energy is invested in the presidency (or, in the case of this study, the candidacy for the presidency)? 2. Positive-Negative Affect: How does the candidate feel about what he or she does? Does the candidate enjoy the experience? The four leadership character categories themselves are:

Active-positive: Lots of activity and an enjoyment of it. Sees positive value in productivity as something to aspire to; Active-negative: Intense effort for low emotional reward. Is aggressive and compulsive. Life is a hard struggle; Passivepositive: Receptive and compliant. Search for affection and aims to soften harsh edges in politics; Passive-negative: Dutiful service replaces low individual self-esteem. ${ }^{47}$

Barber summarises the four characters as follows: "Active-positive presidents want most to achieve results. Active-negatives aim to get and keep power. Passive-positives are after love. Passive-negatives emphasise their civic duty."48

\footnotetext{
${ }^{46}$ Burns, Leadership, p. 58.

${ }^{47}$ Barber, The Presidential Character, pp. 11-13.

${ }^{48}$ Ibid, p. 13.
} 
Alternative frameworks such as those espoused by Neustadt ${ }^{49}$ may not provide further insight on this point but factors leading to leadership analysis are examined. Neustadt's framing ${ }^{50}$ begins by asserting

\footnotetext{
'In the United States we like to 'rate' a President. We measure him as 'weak' or 'strong' and call what we are measuring his 'leadership.' We do not wait until a man is dead; we rate him from the moment he takes office. We are quite right to do so." 51
}

The reality is the candidate is rated much earlier by the public and well before the time they take office. The public rate the candidate on these and other criteria during the campaign. They have made their minds up on the positive and negative aspects of a candidate's character well before the election takes place.

The issue of decision-making is defined as a series of choices and this provides a useful context in which to consider the authenticity of those choices. Neustadt explains it thusly: "By 'choice' I mean no more than what is commonly referred to as 'decision': a President's own act of doing or not doing. Decision is so often indecisive, and indecision is so frequently conclusive, that choice becomes the preferable term." 52

This formulation does not address the role of character, but does make a useful addition to the discourse on authentic decision-making. Neustadt also ensures that sight is not lost of candidates' past performance as a predictor of future capacity, his views linking with those of Burns and Barber when he suggests

"The greatest danger to a President's potential influence ... is not the show of incapacity he makes today, but its apparent kinship to what happened yesterday, last month, last year. For if his failures seem to form a pattern, the consequence is bound to be a loss of faith in his effectiveness next time." 53

\footnotetext{
49 Neustadt, Richard E. (1990). Presidential Power and the Modern Presidents - The Politics of Leadership from Roosevelt to Reagan. New York: The Free Press.

50 The enduring power of Neustadt's work has been challenged and reassessed repeatedly. For a useful summary of this analysis see Hargrove, Erwin C. (June 2001). Presidential Power and Political Science. Presidential Studies Quarterly, 31(2), pp. 245-261.

${ }^{51}$ Neustadt, Presidential Power and the Modern Presidents, p. 3.

52 Ibid, p. 48.

53 Ibid, p. 53.
} 
Consistency is an unavoidable component of character analysis and this is further reinforced by Gardner, when he comments that early influences on a leader's character are profound, drawing attention to four areas: physical vitality and intelligence; capacity to understand and skill in dealing with others; the need for achievement; and confidence and assertiveness. ${ }^{54}$

The importance of this emphasis must be balanced in a contemporary context, in that character development is fluid and can be situational. Leaders are not unchangeable in every setting and Burns emphasises this fluidity:

“... [m] ost of these theories ignore or underplay the force that may be the most important in shaping most leaders: learning. Learning from experience, learning from people, learning from successes and failures, learning from leaders and followers: personality is formed in these reactions to stimuli in social environments." 55

A certain mix of these factors will play a primary role in the development of the character of the leaders under consideration in this study, often one element claiming ascendency over the other. Indeed, the role of background in character development may even have been overstated. Bennis contends that while individuals cannot change the circumstances of their childhoods, they can be recalled honestly, reflected upon, understood and thereby overcome as an influence. ${ }^{56}$ Further, there is an additional ingredient that Neustadt has subtly placed within his perspective on the presidency: "Signs of tenacity count quite as much as signs of skill in shaping expectations of a President's behaviour." 57

Included are references to temperament being a crucial element in behaviour and character assessment. An ability to absorb pressure in circumstances beyond an individual's control is vital to successful leadership and often can only be learned through failure. It is the ability to remain serene in the face of competing interests that,

\footnotetext{
${ }^{54}$ Gardner, On Leadership, p. 163.

${ }^{55}$ Burns, Leadership, p. 63.

${ }^{56}$ Bennis, Warren. (2003). On Becoming a Leader. New York: Basic Books, p. 61.

${ }^{57}$ Neustadt, Presidential Power and the Modern Presidents, p. 53.
} 
along with tenacity, forms a duo of crucial traits in any matrix assessing character and (ultimately) authenticity.

Temperament and drive, as well as a capacity for hard work, are pivotal elements for successful leadership. These two elements intersect in Neustadt's work: “... [i]t is not their drive but their drivenness that sets them [i.e. successful leaders] apart from the rest." 58 An element of character that is not given sufficient focus in the literature on this subject is the element of enjoyment. This is not limited to "self-knowledge", but rather the genuine ease that a person displays in a position of leadership. It goes a long way to making the leader approachable and real.

Further analysis by Hargrove, ${ }^{59}$ although framed almost entirely in a presidential leadership context, adds to the factors to consider when determining authenticity by expanding on some crucial notions. Particularly, he defines character as being in the sense "... of the way people organize their approach to themselves and others, ... [as being] ... a potential skill in the persuasion of others." 60 His framework specifies emotional security as a necessity in relying on strategies of persuasion, while insecure politicians may take refuge in manipulation. ${ }^{61}$ This element has a situational aspect.

The notion of "cultural leadership" is also explored and stated directly:

"The wise politician must acknowledge ... claims ... [of rational solutions to public problems] ..., but also convince them to accept the imperfections of politics. It is just a step from that wise discernment to an unjustified conclusion that the politician knows best because others are too naïve to understand what must be done." 62

Combining purpose and politics is considered by Hargrove to be the primary responsibility of political leadership. ${ }^{63}$

\footnotetext{
58 Ibid, p. 205.

${ }^{59}$ Hargrove, Erwin C. (1998). The President as Leader-Appealing to the Better Angels of Our Nature. Kansas: University Press of Kansas.

60 Ibid, p. 35.

${ }^{61}$ Ibid, pp. 35-36.

62 Ibid, pp. 38-39.

${ }^{63}$ Ibid, p. 39.
} 
A 'teaching reality' is required by a leader to explain and describe the world and their plans for it. Having a view in the first place adds to the authentic nature of a politician's choices. Hargrove stresses that: “The politician's primary criterion for teaching reality, though, must be his audience's assessment of the validity of his message." ${ }^{64}$ The opposite view is also valid, in that pandering to the prejudices of the crowd because they fear reality is an option open to the practitioner of politics. Hargrove summarises his views on this element of leadership:

"Teaching reality ... is teaching what one understands to be moral truths. ... Competitive politics is necessarily a politics of cultural interpretation. Politicians who appeal to the dark side ... are not likely to prevail ... [i]f they do prevail, then the polity is no longer what it was." 65

Hargrove suggests a model of political leadership which has, as part of its focus, character. He draws traits and tendencies together to form the view that "[c]haracter is a skill insofar as it influences the credibility of a leader. Psychological health, moral commitment, and personal integrity, which lend themselves more to persuasion than to control, are the hallmarks of a confident and successful leader."66 Hargrove is convinced that cultural interpretation is the most important task of political leadership, with the achievement of such a task a delicate balance between purpose and prudence. ${ }^{67}$ To do otherwise may lead to leadership by control, appealing to the dark side of society's nature.

Hargrove deepens the understanding of character, adding skill (psychological health, moral commitment and integrity), cultural leadership (balancing purpose and prudence) and most significantly the elusive teaching reality (teaching and preaching), to its dimensions. ${ }^{68}$ These factors and elements of character begin to complete the

\footnotetext{
${ }^{64}$ Ibid, p. 43.

65 Ibid, p. 45.

66 Ibid, pp. 46-47.

${ }^{67}$ Ibid, p. 47.

68 Ibid.
} 
model to be used when examining the events set out in chapters 5 and 8 , but the application of theory must be more than just the matching of traits.

The comprehensive study of traits and tendencies is not enough to get to the core of character. In an effort to add structure, Renshon offers a concise prescription while describing the analysis of character through traits-based evaluations as being too ad hoc. ${ }^{69} \mathrm{He}$ suggests the significance of three psychological elements: ambition, character integrity, and relatedness. He views character as the foundation on which personality rests, defining it as

“... the result of a person's attempt to harness his or her abilities and skills in the service of self-development and life satisfaction. It reflects the person's best attempt to navigate the course of life, resolving, to the extent possible, the basic developmental dilemma."70

Ambition centres on the pursuit of goals and the realisation of values. ${ }^{71}$ Central to this foundation is the notion of achievement. ${ }^{72}$ This concept links the notions of time and energy. ${ }^{73}$ Pointedly, Renshon credits background with a substantial role by arguing that "[c]hildhood grandiosity is the foundation of adult ambition." ${ }^{\circ 4}$ A sense of entitlement that may arise from such attentions will have been reinforced by a sense of 'specialness'. 75

Integrity is the second of these character domains, involving the realisation of a candidate's ideals - but in contrast to achievement is the basis of self-esteem. ${ }^{76}$ Renshon describes how integrity on its own is not enough: “... a person may have developed and refined his or her ideals and values but lack the capacity to realize them

\footnotetext{
69 Renshon, Stanley A. (1996). The Psychological Assessment of Presidential Candidates. New York: New York University Press, p. 181.

70 Ibid, p. 185.

${ }^{71}$ Ibid, p. 186.

72 Ibid.

${ }^{73}$ Ibid.

${ }^{74}$ Ibid, p. 187.

${ }^{75}$ Ibid.

${ }^{76}$ Ibid, p. 188.
} 
in a manner that maintains fidelity to them." $77 \mathrm{He}$ contends that "[f]ailure to consolidate one's ideals also undermines the development of a sense of authenticity ...," 78 an important consideration to examine in chapters 5 and 8. Again, reference is made to background ideals originating from parents, although they develop from experience and ultimately provide an ethical layer to character construction. Renshon identifies two criteria that must be fulfilled to meet that standard: "First, it requires a capacity to endure loss ... [s]econd, one must be able to endure conflict and a degree of separateness from others."79

This goes to the essence of authenticity: the price a candidate is prepared to pay politically in meeting their goals without compromising what they believe in. As Renshon observes,

\begin{abstract}
"[t]he development of integrity suggests the candidate has integrated his basic psychological motivations, skills, and ideals into an authentic, coherent, and consistent sense of who he is and what he stands for. It follows that there is little substantial difference between the person he sees himself to be and would like to be seen as and the person that he really appears to be." (emphasis added) $)^{80}$
\end{abstract}

The third and final foundation is that of relatedness: how the candidate stands and relates to others. ${ }^{81}$ How a candidate's ideals develop will inevitably be bound up in experience and relationships. Whether a contender moves toward, away from or against people, according to Renshon, ${ }^{82}$ will determine how his or her ideals are exhibited. How a candidate views themselves will also be tied to those experiences and relationships with others. In essence, "[m]aking interpersonal connections, sustaining them, and being nurtured by them are basic building blocks of character." 83

\footnotetext{
77 Ibid.

78 Ibid.

${ }^{79}$ Ibid, p. 189.

${ }^{80}$ Ibid, p. 190.

${ }^{81}$ Ibid, p. 192.

82 Ibid, p. 193.

${ }^{83}$ Ibid, p. 194.
} 
Renshon's analysis also includes the operational enactment of character - style. ${ }^{84} \mathrm{He}$ adds depth to his approach by stating that character style develops throughout the life of a political aspirant and can be distinguished through three categories of endowed or developing skill areas: "They are capacities that develop in the cognitive/creative domain, in the interpersonal domain, and in the characterological domain." 85 Renshon further suggests that cognitive elements of character are defined broadly in terms of an 'arena of thought' and whether a candidate takes a broad global view or a detailed analytical view in their thought patterns. ${ }^{86}$

The interpersonal factor involves exhibiting tendencies either to move towards people to maintain close relationships or away from the formation of such relationships. The characterological element is self-belief, encouraging taking courses of action without relying on others (at one end of the scale), and hesitating to take the initiative without approval from others (at the other end). This factor essentially measures or determines resilience and determination in the face of setbacks and can be summed up as the ability to overcome. ${ }^{87}$

Renshon concludes:

"... character does become consolidated and thus stable. That allows the possibility that character will be reflected in publicly observable behaviour, presidential and otherwise. But I have also suggested that elements of character can and do develop. The president ... [or candidate] ... is not simply a child in man's clothing." (emphasis added) ${ }^{88}$

The journey of any one individual evolves. Background is important in determining traits and foundations but the developmental journey of experiences and relationships is what rounds the character out, shaping individual character style, then allowing patterns to emerge that in turn sanction an analysis as to whether an individual decision or choice made is authentic.

\footnotetext{
${ }^{84}$ Ibid, p. 194.

85 Ibid, p. 195.

${ }^{86}$ Ibid, p. 196.

${ }^{87}$ Ibid.

${ }^{88}$ Ibid, p. 203.
} 
In subsequent chapters the conceptual framework outlined in this chapter will be applied at a crucial decision-making moment - when the authenticity of a particular choice was at its most poignant. At that moment, when it mattered most, what this thesis will consider is whether how two candidates reacted to the result given to them (by two of the closest elections in U.S. history) reflected all the different elements of background, character and outlook summed up in the idea of 'authenticity'. 


\section{CHAPTER THREE:}

\section{KENNEDY}

John Fitzgerald Kennedy was born on May 29, 1917 in Brookline, Massachusetts. This chapter will focus on the way that his character developed and the defining influences on his life.

Kennedy's family were outsiders to the political and social establishment and had to fight for recognition. The purposefulness the Kennedy family displayed was not focussed solely on the accumulation of wealth or influence: their quest was for acceptance and more importantly “... its most interesting feature concerns the family's burning desire for respectability and power." 89

Patrick Kennedy, the first Kennedy, arrived in Boston in 1848 and married Bridget Murphy. It was their youngest child, Patrick Joseph, who would reveal the drive and ruthless determination for which the family would become famous.

P.J., as he was known, would marry Mary Hickey, described by Reeves as a "strongwilled young woman" from a prosperous family with political connections at a local level. ${ }^{90}$ But the Irish were outsiders:

"[d]espised by the Anglo-Saxons who ruled the city for their ignorance, their rural customs, their poverty, and their Roman Catholicism, ... '[e]ven the Negro,' wrote Richard J. Whalen, 'with an accepted place as a skilled laborer, faced less discrimination than the Irishman."'91

P.J. brought to the Kennedy lineage a commitment to civic duty and as a popular local character "... he converted his popularity into five consecutive one-year terms in the

89 Reeves, Thomas C. (1991). A Question of Character - A Life of John F. Kennedy. London: Bloomsbury, p. 18.

${ }^{90}$ Ibid, p. 19.

${ }^{91}$ Ibid. 
Massachusetts Lower House, followed by three two-year terms in the state senate."92 But he could not gain the acceptance of the Yankees ruling Boston, and it was those indignities that would drive the ambition of Joseph Patrick Kennedy.

Kennedy Sr. was born on September 6, 1888 and was 'a force of nature'. He eventually attended Harvard, but was never able to gain access to the most exclusive and sought after clubs on campus. While some commentators ${ }^{93}$ attribute Kennedy Sr.'s primary drive being to make money, it was likely he had a bigger plan. His first big opportunity presented itself when he saved Columbia Trust Company and he claimed from that point on that he was the youngest bank president in the United States. But “... [t]he claim was false - historian John H. Davis labels it 'pure Kennedy hype' - but it left many in awe. Joe told a reporter bluntly, 'I want to be a millionaire by the age of 35. $" 994$

In 1906 he met Rose Elizabeth Fitzgerald, the daughter of Boston Mayor "Honey Fitz" Fitzgerald. But even amongst the Irish there was standing to be considered and Honey Fitz "... considered the young man and his family a step down." 95 The problem for Honey Fitz in attempting to resist the marriage was that his own standing as a former mayor was not as high as it had once been. Nevertheless, he was an asset to any Kennedy wanting to understand the complexity of Boston politics. Like P.J., Honey Fitz saw his children as the ultimate way to gain acceptance from the Boston Brahmins and was determined that his daughter Rose be given every opportunity.

\footnotetext{
92 Dallek, Robert. (2003). An Unfinished Life: John F. Kennedy 1917-1963. New York: Little, Brown and Company, p. 8.

${ }^{93}$ Reeves, A Question of Character and Ling, Peter J. (2013) John F. Kennedy. New York: Routledge.

${ }^{94}$ Reeves, A Question of Character, p. 22.

${ }^{95}$ Dallek, An Unfinished Life, p. 19.
} 
Rose and Joseph Kennedy were married on October 17, 1914 and on July 28, 1915, Joseph P. Kennedy Jr. was born. Such was the fanfare that Honey Fitz was to pronounce "Well, of course he is going to be President of these United States!"96

Any examination of the early influence on Kennedy's character is anchored on the resentment felt by both sides of the early generations of his family in being locked out of the highest social strata of society. The central traits of Kennedy's character would ultimately be shaped by the lengths he and his family were prepared to go to achieve respectability.

While Rose was consumed with raising a brood of children, Kennedy Sr. was focussed on making money and moved to managing the operations of Bethlehem Steel's Fore River shipbuilding plant. It was here that Kennedy Sr. was able to transform a $\$ 10,000$ a year job to one that would net him over $\$ 2$ million over the next six years. ${ }^{97}$

At the same time Rose was coping with a three-year-old Jack who was very ill with scarlet fever - it seemed he was about to die, but he recovered a month later. ${ }^{98}$ There would be no sympathy from his father who "... ran the family like a football team. He was coach, the manager, and the referee. Rose was the water boy, constantly filling the children's minds with trivia." 99

In a home life centred on physical activity, sporting prowess and academic achievement, Kennedy Sr. set his own example for the boys.

"Real men were profane, aggressive, and ruthless; they took what they wanted and broke the rules when necessary. Each of the boys, following in their father's footsteps, would strongly

\footnotetext{
96 Perret, Geoffrey. (2001). Jack - A Life Like No Other. New York: Random House, p. 14. See also Ling, John F. Kennedy, p. 9.

97 Dallek, An Unfinished Life, p. 22.

${ }^{98}$ Perret, Jack - A Life Like No Other, p. 20.

${ }^{99}$ Kessler, Ronald. (1996). The Sins of the Father - Joseph P. Kennedy and the Dynasty He Founded. London: Hodder and Stoughton, p. 41.
} 
identify with the church and always attend weekly mass, while doing what was to their advantage with little or no regard to its moral content." 100

The relationship between Kennedy and his older brother was pivotal in shaping Kennedy's psychological makeup. Joe Jr. was strong, intense, and driven and there was no mistaking his lineage. Fierce contests between the two would mean Kennedy would often emerge the worse for wear. "The two once raced around the block on their bicycles in opposite directions, each refusing to veer out of the other's path. The collision sent Jack to the hospital for twenty-eight stitches. His brother was unscathed."101 Significantly Joe Jr. would enjoy robust good health while Kennedy spent a great deal of his youth seriously ill, and although throughout his life "[h]is political courage was sometimes questioned, ... his fortitude in the face of personal suffering was undeniable, and makes his relaxed public persona all the more remarkable."102

According to Reeves, the full extent of his suffering may never be known but the recollection of his brother Bobby is instructive: "At least one half of the days he spent on this earth were days of intense physical pain ..."103

A key influence was his hero, Winston Churchill. Kennedy was an admirer of people with courage but was also fascinated from a young age by international relations and public affairs. In September 1936 Kennedy entered Harvard after his health settled, which meant he was now firmly back in the shadow of his older brother, but he was determined to enjoy himself: "Jack's new friends saw in him little evidence of scholastic ambition."104

Comparisons with his brother were inevitable, but Kennedy worked hard to emphasise the differences.

\footnotetext{
100 Reeves, A Question of Character, p. 31.

101 Ibid, p. 38.

102 Ling, John F. Kennedy, p. 9.

${ }^{103}$ Reeves, A Question of Character, p. 38.

${ }^{104}$ Hamilton, Nigel. (1992). JFK - Reckless Youth. London: Random House, p. 164.
} 
“Joe Jr.'s tutor, Kenneth Galbraith, recorded that Joe was '... much interested in politics and public affairs,' and 'would invariably introduce his thoughts with the words "Father says," whereas Jack 'too was handsome but, unlike Joe, was gregarious, given to various amusements, much devoted to social life and affectionately and diversely to women."'105

At the end of his first year Kennedy travelled to Europe and this experience would impact the way he began to think about international affairs; it was while swimming near Rome that Kennedy badly injured his back while trying to push his car out of the sand. ${ }^{106}$ This would exacerbate a condition that would stay with him right up until his death.

After returning from Europe, Kennedy was informed that his father was to become the American ambassador to the Court of St. James. The ultimate prize in blue-blood acceptance had been achieved by the elder Kennedy, yet when he returned to Harvard at the end of May 1938 "for Joe Jr.'s graduation from Harvard ... [t]he Harvard faculty, asked by the university president to consider giving the ambassador an honorary degree, pointedly declined. Joe pretended not to care, but he felt the edge slide, the point stick."107

It was clear to Kennedy Sr. that despite all he would achieve (by 1957, Fortune would rank his family among America's richest), ${ }^{108}$ there were some doors that an Irishman from his generation could not open. His father's ambassadorial role did have some advantages for Kennedy, who used this opportunity to write his senior thesis on Britain's appeasement policy. Kennedy Sr. had the thesis published as a book entitled Why England Slept. This was an interesting decision by Kennedy Sr. as his ambitions for the family at this time were entirely invested in Joe Jr. To take the step of publishing the writings of the second son was instructive. His investment was rewarded when Kennedy achieved something his father had been unable to do - he had

\footnotetext{
105 Ibid, p. 165.

106 Perret, Jack - A Life Like No Other, p. 58.

${ }^{107}$ Ibid, p. 63.

108 Rubin, Gretchen. (2005). Forty Ways to Look at JFK. New York: Random House, p. 11.
} 
been accepted to join an exclusive club at Harvard. It was the devotion of his friends that got him through the door:

"Several of his friends were being rushed by Spee, and they said they would join only if Jack could join with them ... Franklin D. Roosevelt had been rejected by Porcellian, and that still rankled even after he became President. And Joe Kennedy had never been accepted by any of them: another humiliation at the hands of the Brahmins." 109

With his father now labelled a defeatist by the Roosevelt administration, the younger Kennedy had to decide how closely his views should mirror those of his father. Kennedy did not have the same essential character traits as his brother - he had an inquisitive mind that did not blindly accept the views of his superiors. However, the father/son relationship would not be put to the test for some time. War was imminent. Joe Jr. immediately enlisted in the Naval Reserve and Kennedy (after his father intervened over his poor health record to ensure that his son would serve) was accepted to the Naval Reserve with a Commission. Kennedy was about to add a further title to his list of achievements: hero.

After being assigned to captain a patrol torpedo (PT) boat and being despatched to the Solomon Islands, Kennedy saw early action. Early in the morning on August 2, 1943 a Japanese destroyer ran over the top of PT-109. While the circumstances as to how the destroyer went unnoticed remain unclear, ${ }^{110}$ two members of the remaining crew were killed; the others decided to swim for a nearby island. Kennedy's efforts, under any lens, were impressive: "Jack, swimming on his stomach, towed his wounded crewman by clenching the ties of his life jacket in his mouth ... The swim took five gruelling hours." $" 111$

After the crew was rescued, Kennedy was assigned another PT boat to command and a number of the original crew of PT-109 volunteered to go with him again - reflecting

\footnotetext{
${ }^{109}$ Perret, Jack - A Life Like No Other, p. 67.

${ }^{110}$ Ling, John F. Kennedy, p. 23.

111 Dallek, An Unfinished Life, pp. 95-96. Dallek details the lack of fault on Kennedy's part for the accident but records that PT boats were fast enough to avoid being run over by a destroyer and PT 109 was the only PT ever rammed in the war.
} 
his ability to create a very loyal following. The events were reported very favourably on the front page of the New York Times. The Kennedys had a war hero among them, and his brother Joe Jr. was determined achieve his own honours. Joe Jr. died on August 12,1944 , engaged in a mission that he was warned not to take part in. "Joe ignored the warning and flew anyway...[i]n ignoring [the] warning, Joe Jr. had endangered not only himself but his co-pilot, ... who also died on the mission."112

His brother's death during the war would rewrite Kennedy's own future. He was now custodian of the family's hopes. Kennedy Sr. was crushed by Joe's death and very nearly did not recover. He told friends " [y] ou know how much I had tied my whole life up to his and what great things I saw in the future for him." 113 The view that the tragedy of Joe Jr.'s death alone set Kennedy on a life of public service (the Kennedy family avoided the word 'politics') seems without foundation. Indeed, the innate curiosity Kennedy possessed for public affairs had become more than just a passing interest. Those who served with him say Kennedy always had an interest in politics. According to his commander in the Solomons, Kennedy "spent most of his time looking for officers who weren't in any game, as he did with me. We'd sit in a corner and I'd recall all the political problems in New Jersey and Long Island where I came from. He did that with everybody - discussed politics."114

His father had formed the view that the legacy of the family's expectations would now be passed to the second son. In December 1944, at Palm Beach, Kennedy was told by his father that his job was to take the place of his brother and enter politics:

"the ambassador gave Jack his orders: He was to take Joe Junior's place ... Jack resisted at first; his poor health, his lack of personal experience in the field, and his desire for a life of ease were serious arguments against a political career ... Jack later told reporter Bob Considine, "It was like being drafted. My father wanted his eldest son in politics. 'Wanted' isn't the right word. He demanded it. You know my father." 115

\footnotetext{
112 Kessler, The Sins of the Father, p. 285.

113 Dallek, An Unfinished Life, p. 107.

114 Ibid, p. 113.

115 Reeves, A Question of Character, p. 73.
} 
Kennedy Sr. was even blunter about the expectation: "In August 1957, Joe told a reporter, 'I got Jack into politics. I was the one. I told him Joe was dead and that it was therefore his responsibility to run for Congress." 116 Ultimately, Kennedy would accept the mantle passed to him. The founding father was not to be denied: "Kennedy never denied his father's influence. 'He's the one who made all this possible,' JFK told a friend not long before the assassination." 117

A more recent body of literature puts an alternative view to this proposition ${ }^{118}$ - that in fact the influence of Kennedy's father was not completely invasive. Oliphant and Wilkie go so far as to state: “The force behind Kennedy's ambition was Kennedy himself."119 Substantial revisionist work has attempted to minimise the elder Kennedy's importance ${ }^{120}$ but the reality is that the ambassador was directing his son's political career - down to the smallest detail. Later in his political life (during his bid for the presidency) keeping the controversial father out of the limelight was essential for campaign success, but Kennedy never broke loose from the influence of his father; in fact, he initially welcomed it to ensure his first electoral success: what Joe wanted, he got.

From the first time he ran for office Kennedy must have realised that his behaviour would have to alter. Kennedy had a disregard for rules and norms and many of the activities he engaged in as a young man are set out in Nigel Hamilton's book aptly titled Reckless Youth. ${ }^{121}$ Kennedy was young, wealthy, and rebelling against the influence of his father and brother and had a heightened sense of his own mortality.

\footnotetext{
116 Dallek, An Unfinished Life, p. 118.

117 Rubin, Forty Ways To Look At JFK, p. 71.

118 See Shaw, John T. (2013). JFK in the Senate - Pathway to the Presidency. New York: Palgrave Macmillan, pp. 12-15 and Oliphant, Thomas \& Wilkie, Curtis. (2017). The Road To Camelot-Inside JFK's Five-Year Campaign. New York: Simon \& Schuster, pp. 7-9.

119 Olipant and Wilkie, The Road To Camelot, p. 8.

${ }^{120}$ Reeves, A Question of Character, p. 77.

${ }^{121}$ Hamilton, JFK - Reckless Youth.
} 
The essential character question is whether this recklessness played through into his decision-making in a consistent (authentic) manner.

For Kennedy's first campaign no expense was spared to ensure success. Dallek writes that although the exact amount is unknown, Kennedy Sr. may have spent between $\$ 250,000-\$ 300,000$, an enormous amount of money at that time. Pollsters, billboards, professional public relations firms, five campaign offices through the district and with the entire family and friends pitching in meant Kennedy's opponents were swamped. ${ }^{122}$ Kennedy Sr. is said to have bragged "... with what I am spending I could elect my chauffeur." ${ }^{\prime 23}$ Being the only World War II veteran in the race helped, but it was the father's money that would prove decisive. On June 18, 1946, Kennedy won the Democratic nomination with $42 \%$ of the vote, with the primary campaign being summarised in the words of a newspaper ad attacking Kennedy: "CONGRESS SEAT FOR SALE, No Experience Necessary. Applicant must live in New York or Florida. Only Millionaires need apply." 124

On November 5, Kennedy's Republican opponent, Lester Bowen, managed only 26,007 votes to his 69,093 . It was not only a significant victory in the Eleventh District, but state and nationwide where "[i]n Massachusetts, the Democrats lost a U.S. Senate seat and the governorship; nationally, the Democrats lost control of both houses of Congress for the first time since 1930." 125

Kennedy's career as a congressman was unremarkable. "Jack had one of the worst absentee ratings in the House and sponsored no noteworthy legislation." 126

\footnotetext{
122 Dallek, An Unfinished Life, pp. 130-131.

${ }^{123}$ Ibid, p. 130.

${ }^{124}$ Reeves, A Question of Character, p. 83.

125 Dallek, An Unfinished Life, p. 133.

${ }^{126}$ Rubin, Forty Ways to Look At JFK, p. 36.
} 
In 1947 Kennedy was diagnosed with Addison's disease, but he only rarely let on that he had the ailment. If this was not affecting the shaping of his character enough, in May 1948 his beloved sister Kathleen was killed in an airplane crash. Kennedy was crushed. ${ }^{127}$ His own sense of mortality must have been further heightened, as what he recalled most about his sister and indeed Joe Jr. was their sense of vitality. ${ }^{128}$ He set his sights on the 1952 race for the Senate and travelled extensively through Europe, but Kennedy's health was deteriorating badly and he "... took hot baths each day and slept with a stiff board under his mattress. Daily doses of cortisone helped him survive extremely long days." 129

Despite all these obstacles, on April 6, 1952 Kennedy announced he would run for the U.S. Senate against the Republican incumbent, Henry Cabot Lodge Jr. who was “... handsome, urbane, Harvard-educated, and a Yankee Brahmin of the sort likely to irritate
Joe and Rose Kennedy, ... [b]y 1952 a perceptive article in the Reporter described the fifty-
year-old incumbent as 'at the peak of his power, prominence and experience."”130 The Lodge machine simply did not have the resources to match the Kennedy effort. Dallek describes how Joe, during the campaign, loaned $\$ 500,000$ to John J. Fox, the owner of the Boston Post - Jack got a Post endorsement less than two weeks before the election. ${ }^{131}$ Kennedy would win by a narrow margin of 70,737 votes out of $2,353,231$ cast $-51.5 \%$ to $48.5 \%$. Lodge himself summed it up best in the aftermath of a campaign that saw him forced from office after being unbeaten since 1932: "I felt rather like a man who has just been hit by a truck." 132 The Kennedys had beaten the very embodiment of the establishment.

In September 1953 Kennedy, aged thirty-six, married Jacqueline Bouvier, who was just twenty-four years old. The wedding was heavily publicised, but his back pain was

\footnotetext{
127 Perret, Jack - A Life Like No Other, p. 159.

128 Dallek, An Unfinished Life, p. 154.

${ }^{129}$ Reeves, A Question of Character, p. 97.

${ }^{130}$ Ibid, p. 98.

${ }^{131}$ Dallek, An Unfinished Life, pp. 171-172.

132 Ibid, p. 174.
} 
now crippling and two operations were required in 1954 and 1955 . When the Senate voted to censure Senator McCarthy, Kennedy failed to vote - the only Senator to do so. He would argue he was recuperating but he could have paired his vote. This was a telling insight. ${ }^{133}$

This inaction goes to the heart of the traits Kennedy had displayed since serving in elected office. He appeared only concerned with the next election. In many respects his decision to write a book in 1957 about Senators who risked their careers to take principled stands on issues (Profiles in Courage) could be seen as an effort to make up for this failure, because the McCarthy issue remained a thorn in his side.

Despite this issue Kennedy went on at the Democratic Convention in 1956 to narrate a film about the history of the Party. He was warmly received - the New York Times reported that he "came before the convention tonight as a movie star." 134 In fact when the floor was opened for the vice-presidential nomination for the 1956 presidential election, he came very close to winning it - but was defeated by Tennessee Senator Estes Kefauver. Tellingly, the decision to allow his name to go forward was Kennedy's - over the wishes of his father, who thought it a terrible mistake: “... According to Rose Kennedy and Kenny O'Donnell, Joe exploded in anger. He 'denounced Jack as an idiot who was ruining his political career."'135

While Kennedy tried desperately to forge his own way, keeping his father hidden to the outside world, he could not win without him and when he deliberately decided to run counter to his wishes (at the 1956 Convention) he did so only as a one off, never as a concerted effort.

Kennedy also balanced other competing traits from his personality that would affect his decision making over his career; not all were situational. His own poor health and

133 See Shaw, JFK in the Senate, p. 64. Ted Sorensen, a senior Kennedy aide, acknowledged in his 2008 memoir that "JFK showed no courage on that vote".

134 Rubin, Forty Ways to Look at JFK, p. 37.

135 Dallek, An Unfinished Life, p. 207. 
deeply ingrained sense of mortality would hasten decisions, bringing an element of recklessness to his actions. The over-compensation to be better than his peers and to embody the concept of 'excellence' almost certainly grew from a sense that he needed to compensate both inside and outside his family for the deaths of his brother and sister. The award of a Pulitzer Prize for Profiles in Courage, although not without controversy, would bolster his 'excellence' credentials. Ultimately though, Kennedy possessed a charm and ease of manner that shone through these competing character traits - all while enduring considerable pain.

What remained most intriguing was which of those elements of his character would become dominant in the most significant quest an Irish Catholic could contemplate in fulfilling a desire for recognition and respectability - the quest for the White House. 


\section{CHAPTER FOUR:} NIXON

Richard Milhous Nixon was born on January 9, 1913 in Yorba Linda, California. Nixon was so dominant in the Republican Party that he was chosen to run on five national tickets, a distinction shared only by Franklin D. Roosevelt. ${ }^{136}$

Gergen describes Richard Nixon as the most fascinating man he met in thirty years of public life, ${ }^{137}$ a notion reinforced by Time magazine which put him on the cover no less than 56 times. ${ }^{138} \mathrm{He}$ also reflects that when an international crisis broke out after he left office, one of the first questions of every president he had known since was: I wonder what Nixon thinks? ${ }^{139}$

Unlike other candidates in this study, Nixon did not come from a wealthy background, but like the others, he would know tragedy early in his life.

The differences between his father and mother were stark and go some way to explaining what has been described as the 'Jekyll and Hyde' Nixon. ${ }^{140}$ Hannah Milhous was brought up as a Quaker and her family settled in California. Her father, Franklin, was respected in the community and the family was happy and prosperous enough that “... [Franklin] ... saved enough money to establish a trust fund at Whittier College for his grandchildren's education."141

\footnotetext{
${ }^{136}$ McPherson, James M. (ed.). (2000). "To the Best of My Ability" - The American Presidents. New York: Dorling Kindersley Publishing, p. 267.

${ }^{137}$ Gergen, David. (2000). Eyewitness To Power. New York: Touchstone, p. 20.

138 Ibid, p. 21.

${ }^{139}$ Ibid, p. 28.

140 Greenstein, Fred I. (2000). The Presidential Difference: Leadership Style from FDR to Clinton. New York: The Free Press, p. 93.

${ }^{141}$ Ambrose, Stephen E. (1987). Nixon. Volume I - The Education of a Politician 1913-1962. New York: Simon and Schuster, p. 10.
} 
Hannah Milhous led a sheltered life and was serious and earnest but was swept off her feet by Frank Nixon at a Quaker Valentine's party in 1908. ${ }^{142}$ She was pious, tolerant, loving, almost naïve. He was headstrong and aggressive; his stubbornness or singlemindedness was both a gift and a curse. But for all the references Nixon would make to the poverty the family lived in while he was growing up, it did not begin that way. In fact, Hannah's father advanced “... three thousand dollars - the equivalent of some fifty-two thousand dollars ... [in 2000] ... - to build their first home and start the lemon grove at Yorba Linda, thirty miles from Los Angeles." 143 The couple had five children. His mother would explain to Nixon he was named for King Richard the Lionheart.

Life was difficult for the family. The land was not suitable for lemons and according to Summers, Frank would not take advice on how to improve it. ${ }^{144}$ Nixon would often refer to the poverty he had endured as a youngster, telling a reporter

\footnotetext{
"We were poor, ... We had very little." On other occasions he came closer to the probable truth. "It's been said our family was poor ... but we never thought of ourselves as poor. We always had enough to eat, and we never had to depend on anyone else." 145
}

The transition for Hannah must have been significant: coming from a close-knit and prosperous family she supported her family and husband against the odds, taking work herself to supplement the family income by working at the local SunKist fruit-packing factory.

Nixon would refer to this time in his life many times and label himself 'a battler'. He was a fighter, and his background reinforced that pedigree. ${ }^{146} \mathrm{He}$ worked hard at

\footnotetext{
${ }^{142}$ Summers, Anthony. (2000). The Arrogance of Power: The Secret World of Richard Nixon. London: Victor Gollancz, p. 5.

${ }^{143}$ Ibid, p. 6.

144 Ibid.

${ }^{145}$ Ibid.

${ }^{146}$ Nixon as a youngster has been described latterly as " a daydreamer, a cloud counter, a bookworm ..." See: Farrell, John A. (2017). Richard Nixon. The Life. New York: Vintage Books, p. 3.
} 
promoting it, and even as he left the White House he still repeated the story he had used many times throughout his political career:

\begin{abstract}
"I remember my old man," Nixon told his audience. "I think they would have called him sort of a little man ... he had a lemon ranch. It was the poorest lemon ranch in California. ... He sold it before they found oil on it ..."

"My mother," the president went on, "was a saint. And I think of her two boys dying of tuberculosis, nursing four others in order that she could take care of my older brother for three years in Arizona, and seeing each of them die ... she will have no books written about her. But she was a saint.".147
\end{abstract}

Although they were relatively poor, Hannah was determined her children would go to college. She committed herself to this cause and this approach would mirror characteristics Nixon would exhibit in his own pursuit of excellence and achievement. His mother "... instilled in the family this seriousness about growing up and being somebody." 148 The effect of growing up in a household with two markedly different parents was not lost on Nixon in later years when examining his own character.

"In his memoirs, written after his presidency, Nixon provided a psychological self-analysis of the effect on him of the daily dinnertime confrontations ...: 'Perhaps my own aversion to personal confrontations dates back to these early recollections." "'149

At a young age he set himself goals and targets. He was different; when he started school, he was regarded early on as mature. "He was thoughtful and serious. 'He always carried such a weight." "150

As a keen student Nixon applied himself without encouragement and presented as earnest and undemonstrative. It would not, as Ambrose contends, be correct to conclude his character was shaped solely by his religious affiliation. Other traits emerged and although he was inward looking and sensitive to criticism, he would force himself outside his comfort zone into situations which felt unnatural. "In the

\footnotetext{
${ }^{147}$ Summers, The Arrogance of Power, p. 2.

148 Ambrose, Nixon: Volume I - The Education of a Politician, p. 25. See also Farrell, Richard Nixon. The Life, p. 4.

${ }^{149}$ Ambrose, Nixon: Volume I-The Education of a Politician, p. 26.

${ }^{150}$ Ibid, p. 27.
} 
process he developed a tremendous willpower, an ability to make himself do things." 151

These traits would become essential elements of Nixon's character. Relatedly, his inability to get close to people would be an element of his personality that would be noted by others. Farrell describes charm for Nixon being "an act of will". ${ }^{152}$ It is likely deeply rooted in his relationship with his mother, who was not at all demonstrative towards her children, and in fact Summers recalls Hannah “... never kissed him, ever." 153 Those tendencies would deepen as tragedy struck early in Nixon's life. When Nixon was twelve years old his brother Arthur died. "The death certificate ... attributed Arthur's death to 'encephalitis or tubercular meningitis."'154

A tangible affect of this loss was to make him work harder. He was determined to make up the loss, and five years after the funeral Nixon wrote

“"And so when I am tired and worried, and am almost ready to quit trying to live as I should, I look up and see the picture of a little boy with sparkling eyes, and curly hair." "The image was enough to make him work harder, try harder.""155

His brother's death would help contribute to a willpower and resolve that would shape Nixon into a brooding and introspective individual. Ambrose does not view the death of Nixon's brother as a major factor in shaping the person Nixon became, ${ }^{156}$ but it would become a reason for him to strive even harder.

Tragedy continued to shape Nixon. A second sibling, his older brother Harold, would also die. TB struck Harold in 1927, shortly after Arthur's death, and meant Hannah spent long periods away from the family looking after his needs in a sanatorium in Arizona. To help ease the financial burden, she rented a log cabin and cared for Harold

\footnotetext{
${ }^{151}$ Ibid, p. 33.

152 Farrell, Richard Nixon. The Life, p. 8.

${ }^{153}$ Summers, The Arrogance of Power, p. 9.

154 Ibid.

${ }^{155}$ Ambrose, Nixon. Volume I-The Education of a Politician, p. 42.

156 Ibid.
} 
and three other TB patients. Ambrose further notes that Nixon kept up a brutal schedule through his high school years and into College, ${ }^{157}$ while all the time dealing with the death of his two brothers. Nixon was not a gifted student, but a toiler who worked hard for the grades he obtained. Pure application saw him score very good grades but, to reflect his own words, "It isn't luck. You've got to dig for them." 158

In his senior year at high school further misfortune would strike. He would finish high school as an honour student and would earn the Harvard Club award as "best allaround student." The award gave Nixon a scholarship to Harvard, but because of the financial impact on the family, he was unable to take it up and had to settle for Whittier College. ${ }^{159}$ Thus commenced a life-long disregard for the Eastern elite he would come to loathe. Nevertheless, he followed his established formula and threw himself into life at Whittier College with drive and determination; during this time his older brother finally gave up the fight with TB and died. The effect on Nixon was immediate:

\footnotetext{
“'Richard sank into a deep, impenetrable silence,' Hannah remembered. 'From that time on, it seemed he was trying to be three sons in one, ... I think Richard may have felt a kind of guilt that Harold and Arthur were dead, and he was alive."'160
}

In May 1933, he ran against a student named Dick Thomson in a campus election. Thomson belonged to the Franklin society, which Nixon had not been invited to join. Nixon won, appealing to those who were on the outside and promising to allow dancing on campus. ${ }^{161}$ The themes he articulated would prove instructive when looking at his future campaigns: a populist issue combined with seeking out a demographic group who felt 'unheard' - it would become vintage Nixon.

\footnotetext{
${ }^{157}$ Ibid, p. 45.

${ }^{158}$ Ibid, p. 49.

${ }^{159}$ Ibid, p. 50.

${ }^{160}$ Summers, The Arrogance of Power, p. 11.

${ }^{161}$ Ambrose, Nixon. Volume I - The Education of a Politician, p. 60.
} 
Nixon finished his schooling as a success and "[i]n June 1934, ... graduated from Whittier College. He was on the honor society for the fourth straight year, and was second in his class." 162 Following his graduation, he gained a scholarship to Duke University to study law in North Carolina. Duke Law School would make him realise that to compete with the best would require more from him than just an ability to debate well. Nixon had a determination to succeed that even those who were brighter than he would notice and remark upon: “... a classmate put it bluntly when he called Nixon 'the hardest-working man I ever met.""163

Nixon won admiration, but not friends. An interesting set of traits was emerging in Nixon's life - when the odds were against him, he sought through willpower and hard work to overcome those circumstances. At Duke, that approach paid off. He graduated in June 1937 and "... had come third in his class of twenty-six, with an 80.49 average, qualifying for a prestigious national legal honor society. He had, moreover, been president of the Duke Bar Association."164

Dean Horack had given him the best advice possible when Nixon missed out on a job at the FBI: “... if you're going to go into politics, go back to your hometown and establish yourself in a law firm." 165 So, at twenty-four years old he returned to Whittier, passing the California bar exam and commencing the practice of law; he also began courting the woman who would be known as Pat Nixon. They were married on June 21, 1940 despite the fact that Nixon had almost no ability to engage in small talk with anyone and remained socially awkward. An example of this awkward approach highlights the trouble Nixon had later on:

\footnotetext{
"When the Shah of Iran was in Washington ... [William Watts] ... watched Nixon going around the room shaking hands with a group of women. As he came to each one, he would say 'Hello, I'm Richard Nixon.' And he came to another one and ... [Watts] ... heard him say again, 'I'm Richard Nixon ... [s] he just replied, 'Yes, dear, I know. I'm Pat. ..."'166
}

\footnotetext{
${ }^{162}$ Ambrose, Nixon. Volume I - The Education of a Politician, p. 70.

163 Ibid, p. 75.

164 Summers, The Arrogance of Power, p. 21.

${ }^{165}$ Ambrose, Nixon. Volume I-The Education of a Politician, p. 83.

${ }^{166}$ Summers, The Arrogance of Power, p. 37.
} 
In 1941 the Nixons moved to Washington and in April 1942 he applied to the Navy, something he did not have to do with a Quaker background; however, military service was a necessary step to a political career. ${ }^{167}$ The war was a turning point and "... Nixon saw the war as 'the catalyst' that had transformed his interest in politics into a sense of mission." 168 According to Ambrose the war had taught Nixon the odd lesson: "He learned the ways of the world, and a great deal more about his own potentials, as a leader, poker player, and - perhaps - politician." ${ }^{169}$ He excelled at the game of poker, returning from the Solomons to the U.S. with a nest egg of $\$ 10,000 .{ }^{170}$ In September 1945 Nixon received a letter from California asking if he wanted to run as a Republican candidate for Congress in the 1946 elections. ${ }^{171}$

In a gesture that would be mirrored in campaigns to come, Nixon had not sought a specific congressional district nor actively pursued a political favour: the party had approached him. His opportunity was not purchased for him, nor did he have any political lineage to rely on. He was, and would always regard himself as, an outsider.

Nixon managed to impress the Committee of $100^{172}$ sufficiently to win the Republican primary, but in a poor error of judgment the Democratic incumbent did not take the challenge from Richard Nixon seriously at first. Jerry Voorhis had won five straight elections in the $12^{\text {th }}$ Congressional District (the area east of Los Angeles) and was a formidable opponent to topple, but Nixon was no ordinary challenger. “... Nixon

\footnotetext{
${ }^{167}$ See Farrell, Richard Nixon. The Life, p. 76. “... no one with Dick’s ambition could fail to recognise that time in uniform would be an almost indispensable prerequisite for leadership after the war."

168 Ibid, p. 7.

${ }^{169}$ Ambrose, Nixon. Volume I - The Education of a Politician, p. 115.

170 Matthews, Christopher. (1996). Kennedy \& Nixon - The Rivalry that Shaped Postwar America. New York: Simon \& Schuster, p. 33.

${ }^{171}$ Summers, The Arrogance of Power, pp. 41-42.

172 The Committee of 100 - also known as the "Twelfth Congressional District Republican Candidate and Fact Finding Committee" - was a local business group hoping to unseat the Democrat, Jerry Voohis. See: Matthews, Kennedy \& Nixon, p. 34, and Farrell, Richard Nixon. The Life, p. 13 and pp. 23-24.
} 
resumed his hectic speaking schedule. He directly attacked the vulnerabilities of the Truman administration and connected them to Voorhis." 173

Constant accusations of communist associations directed towards Voorhis would eventually take their toll, foreshadowing the type of tactics Nixon was to apply in his other campaigns. The lengths Nixon went to would be revealed by Nixon himself when he admitted in private:

\footnotetext{
"“I know Jerry Voorhis wasn't a communist. ... I suppose there was scarcely ever a man with higher ideals than Jerry Voorhis, or better motivated. ... But ... I had to win. That's the thing you don't understand. The important thing is to win." " 174
}

Nixon secured a margin of more than 15,000 votes, $56 \%$ of the total. His re-election in 1948 was even more impressive. According to Gellman, the campaign of 1948 was out of character - "clean, well run, managed by amateur-turned-professional supporters under Nixon's close guidance." 175 However, the attention Nixon received for his initial election victories were minimal compared to the national attention he would gain for pursuing Alger Hiss.

In August 1948, Time magazine editor Whittaker Chambers told the House Committee on Un-American Activities (HUAC), of which Nixon was a member, that he had been a member of the Communist underground in the 1930's and while attending meetings had observed rising diplomat, Alger Hiss. Chambers accused Hiss of being a Communist. When Hiss first appeared before HUAC two days after Chambers to answer accusations, he was convincing in setting aside the claims. But he made a fundamental error. As a Harvard man he chose to make fun of Nixon and the fact he had attended Whittier College. ${ }^{176}$

\footnotetext{
${ }^{173}$ Gellman, Irwin F. (1999). The Contender-Richard Nixon: The Congress Years. New York: The Free Press, p. 64.

${ }^{174}$ Summers, The Arrogance of Power, p. 45.

${ }^{175}$ Gellmann, The Contender, p. 179.

${ }^{176}$ Farrell, Richard Nixon. The Life, pp. 114-115.
} 
While the rest of the Committee and the media were sure Hiss was the victor and that any further pursuit was just vindictive, Nixon pressed on, tirelessly employing a defining intensity of purpose. His cross-examination of Hiss was pointed, leading and merciless. Nixon won the day:

"In December [1948] ... [Hiss] was indicted on two counts of perjury: that he had lied to Congress about not stealing State Department documents and about not knowing Whittaker Chambers. The statute of limitations protected Alger Hiss from an espionage charge." 177

The image of Nixon as a vengeful pursuer of Communists was now set. The price of failure would have been high. ${ }^{178}$ But Nixon took that calculated risk and he was now on the national stage, and at age thirty-five, he had serious political coattails. He decided to make the jump to the U.S. Senate.

Taking on Congresswoman Helen Gahagan Douglas added to Nixon's reputation as an ambitious anti-communist crusader. In his own words: “"The House,' he told a friend, 'offered too slow a road to leadership, and I went for broke." ${ }^{179}$ Summers refers to the fact that of twelve newspapers in California, nine backed Nixon. With money from big business, Nixon was well financed and his friend Murray Chotiner was at the helm of the campaign - a sure indication of the direction the campaign would take.

Dubbing Douglas the "Pink Lady", and printing more than half a million pamphlets on pink paper, had the effect of confirming the message that Douglas was a Communist. The gentlemanly tactics of the 1948 campaign were abandoned for the type of campaign Nixon was most at home with: a take no prisoners battle. Nixon was prepared to do whatever it took to win, continuing to embed this series of traits even more deeply into his character. He even resorted to infamously saying of his opponent “... [she was] ... pink right down to her underwear." 180

\footnotetext{
177 Matthews, Kennedy \& Nixon, p. 64.

${ }^{178}$ Not all of the coverage following the hearings was positive. See: Buchanan, Patrick J. (2014). The Greatest Comeback - How Richard Nixon Rose from Defeat to Create the New Majority, New York: Penguin Random House, pp. 12-13.

${ }^{179}$ Summers, The Arrogance of Power, p. 83.

${ }^{180}$ Matthews, Kennedy \& Nixon, p. 72.
} 
On election night he won by a margin of 680,000 votes. It was the largest plurality of any Senate winner of that year. Nixon attracted 2,183,454 votes to Douglas' 1,502,507 votes. ${ }^{181} \mathrm{He}$ gained $59 \%$ of the vote. As described by Farrell: "He had crushed Helen Douglas ..."182 Senator Sheridan Downey almost immediately after the election announced his resignation, allowing Nixon to be sworn in. This made Richard Nixon, at thirty-seven, the youngest member of the Senate. ${ }^{183}$

By any standard, what Nixon had achieved to date was impressive. He had (almost), through pure grit, battled his way from that lemon farm and the tragedy of his brothers' deaths; from the lost chance to attend Harvard; from Whittier College and practising law in the town itself; to the House, and now to the Senate, all before turning thirtyeight years old. But what of the person and the development of his character?

Nixon now appeared vindictive and without political sportsmanship. His tactics had cast a shadow over his successes, and they would need to be altered if he decided to pursue further political office, but he was now "the party's most sought-after speaker." 184 He had become the darling of the right-wing of the Republican Party and when in January 1952, Eisenhower's name appeared on the New Hampshire ballot Nixon's name was being floated as his running mate.

When Eisenhower emerged the victor at the convention, all that remained was for him to select a running mate. Nixon was picked, and although the relationship with Eisenhower was not a warm one, within a week of the convention Nixon appeared on the front cover of Time.

\footnotetext{
${ }^{181}$ Ambrose, Nixon. Volume I - The Education of a Politician, p. 223.

182 Farrell, Richard Nixon. The Life, p. 156.

${ }^{183}$ Matthews, Kennedy \& Nixon, p. 74.

${ }^{184}$ Ambrose, Nixon. Volume I - The Education of a Politician, p. 225.
} 
Shortly after the nomination was confirmed, journalists wrote a story alleging Nixon had a secret fund that backers placed money in to supplement his personal income as a Senator. Eisenhower required a full disclosure and was confronted with demands to get Nixon off the ticket before it ruined the Republicans' chances in 1952. Thomas Dewey called Nixon and told him "the General's advisers thought he should resign". ${ }^{185}$ Nixon was furious, famously telling Eisenhower in a call before the broadcast: " $[t]$ here comes a time in matters like this when you've either got to shit or get off the pot..."186

Nixon dug deep into his reservoir of self-belief and determination - his entire political career was on the line and possibly the outcome of the 1952 presidential election. This was the moment when years of pushing himself into uncomfortable situations and forcing himself to perform would pay off.

In probably the most dramatic televised address in U.S. history (up until that point) Nixon, alone, stared into the living rooms of 58 million people and the new Nixon was born: the battler. The Checkers speech was a masterstroke. Many of the lines are now part of the political lexicon - his wife's cloth coat, the dog Checkers and the public revealing of his most basic trait: "I don't believe that I ought to quit, because I am not a quitter."187

In a direct appeal to his "silent majority", Nixon asked viewers to telegraph or write to the Republican National Committee as to whether he should stay or go. The response was 350 to 1 in favour of Nixon. ${ }^{188}$ Eisenhower had little choice: Nixon would stay on the ticket; he had shown his own toughness, and had also discovered his own political power base.

\footnotetext{
185 Summers, The Arrogance of Power, p. 119.

${ }^{186}$ Ambrose, Nixon. Volume I - The Education of a Politician 1913-1962, p. 282.

187 Ibid, p. 289.

${ }^{188}$ Ibid, p. 290.
} 
On January 20, 1953, Nixon took the oath of office as Vice-President of the United States. He had just turned forty years old and was the second youngest vice-president in U.S. history. At the end of that eight year period he would be the clear favourite for the Republican nomination for the presidency. He realised he could not outshine Eisenhower while he was vice-president and took the opportunity to forge a "new Nixon'. This Nixon was less combative and less vindictive. He would aim to become a statesman because he had to. Nixon was aware he needed to change to achieve the next and final political challenge - which hints at a lack of authenticity in his character to this point. In fact, he had already shown his ability to change his methods in the 1948 congressional campaign, where a more measured Nixon emerged, and he was electorally rewarded for that decision.

Having served as a Congressman, a U.S. Senator and as Vice President for eight years, Nixon was arguably the most well-prepared candidate for the country's highest political office. His profile had kept him centre stage since 1946. The 1960 election would be Nixon's to lose. 


\section{CHAPTER FIVE:}

\section{THE 1960 ELECTION}

This chapter will focus on several different aspects of the 1960 election including the nomination process and primary competitions for each candidate; the role of President Eisenhower; the selection of a vice-presidential candidate and the outcome of the election itself.

The primary part of this chapter will apply the theoretical models outlined in chapter 2 to the decisions made by each of the candidates before, during and, in the case of Nixon, after the election campaign.

Following the presidential election on November 8, 1960 the result was so close that the outcome was not immediately certain. Eventually though the Democratic ticket of Kennedy and Johnson would beat the Republican ticket of Nixon and Lodge. The two Democrats gained 34,226,731 popular votes compared to their opponents' $34,108,157$ - a difference of less than 120,000 votes. Under the electoral voting system, however, the victory was more decisive, with the Kennedy/Johnson ticket securing 303 electoral votes to 219 for Nixon/Lodge. It should be noted that an independent ticket of Senators Harry F. Byrd (Virginia) and J. Strom Thurmond (South Carolina) gained 15 electoral votes. 
The 1960 election has been studied ${ }^{189}$ as a watershed election for a number of reasons. It would see

"[f]ive candidates seriously seeking the presidency for the first time in $1960 \ldots$... [eventually they would] ... become either president or vice president in the next sixteen years. Never before in history had one election produced such a collection of new and influential candidates." 190

These five candidates - Kennedy, Johnson, Nixon, Hubert H. Humphrey and Nelson A. Rockefeller - would remain influential figures in U.S. history. Liebovich makes the point that for the first time in over 100 years, the vice president was considered seriously as a viable contender, rather than a political placeholder. ${ }^{191}$

Significant, too, was the trend that the traditional party machine would end its dominance, with the presidential primary elections now a testing ground for public appeal. The Democratic field for the nomination was crowded from the start. The former governor of Illinois, Adlai Stevenson, would not commit to throwing his hat into the ring but could not be discounted as the party's two time representative (and loser) in 1952 and 1956. Johnson himself was a strong contender with his impressive control over party machinery and as majority leader of the U.S. Senate. Also in the mix was Senator Stuart Symington of Missouri, who had the support of Harry Truman but was generally not well known. That left senators Hubert H. Humphrey of Minnesota

${ }^{189}$ As examples of more recent literature see:

Donaldson, Gary A. (2007). The First Modern Campaign - Kennedy, Nixon, and the Election of 1960. Maryland: Rowman \& Littlefield Publishers.

Kallina, Edmund F. Jr. (2010). Kennedy v. Nixon - The Presidential Election of 1960. Gainesville: University Press of Florida.

Pietrusza, David. (2008). 1960 - LBJ v JFK v Nixon. The Epic Campaign that Forged Three Presidencies. New York: Diversion.

Rorabaugh,William J. (2009). The Real Making of the President. Kennedy, Nixon, and the 1960 Election. Lawrence: University Press of Kansas.

${ }^{190}$ Liebovich, Louis W. (1998). The Press and the Modern Presidency: Myths and Mindsets, from Kennedy to Clinton, Connecticut: Praeger, p. 4.

191 Ibid. 
and John F. Kennedy. Both were prepared to gamble on gaining momentum from the primary races.

Kennedy may have been young and somewhat unknown but "[m]oney and organisation were John F. Kennedy's strengths. His family both funded and staffed a massive campaign organisation ... [h] e nominated Stevenson at the Democratic convention in $1956 \ldots$... [had a] ... Pulitzer-Prize winning book ... [but was regarded as] ... inexperienced." 192 Aside from the inexperience label, religion emerged as a stumbling block for the young Kennedy. No Catholic had ever been elected to the presidency and only one, Al Smith, had even been nominated, losing badly (in 1928). Kennedy chose to address these issues prior to the convention in July 1960 through the primary races.

The quest for popular appeal through the primary season would initially focus on two states - Wisconsin and West Virginia. Wisconsin was the first state where Humphrey and Kennedy would go head to head and the first time Humphrey would be made fully aware of the massive resource available to the campaign by Kennedy's father. Wisconsin, bordering on Humphrey's home state, was a must win for him. He lost. Kennedy took $56 \%$ of the vote, and it seemed his Catholicism worked for him

\footnotetext{
“... the verdict was still out on a Kennedy candidacy, in part because Catholics provided a substantial portion of his vote. Because some of them were conservative Republicans who crossed party lines in Wisconsin's open primary, that state did not prove to be the convincing victory Kennedy so desperately needed."193
}

The campaign moved on to West Virginia where Protestants made up 95\% of the population. Kennedy went directly to the medium that would serve him so well television. A 30-minute broadcast addressed the issue of his Catholicism when he pledged to keep church and state separate. Kennedy won handsomely, taking $61 \%$ of the vote to Humphrey's $39 \%$. Humphrey withdrew from the race. ${ }^{194}$ At the national

\footnotetext{
192 Coenen, Craig R. (2003). The Election of 1960. In William G. Shade \& Ballard C. Campbell (eds.), American Presidential Campaigns and Elections. New York: M.E. Sharpe, p. 851.

193 Ibid.

194 Ibid, pp. 851-852.
} 
convention Kennedy won the nomination on the first ballot “... with 806 votes, nearly twice the 409 that Lyndon Johnson received."195

The choice of Johnson for a running mate was calculated and deliberate. With his powerful connections on the Hill and links to the old powerbrokers of the party, having him on the ticket was critical: but the most important quality he brought to the pairing was his influence in the South. ${ }^{196}$ According to Rorabaugh: "Sam Rayburn believed that Johnson was the first vice president on a ticket to have made much of a difference since Teddy Roosevelt ran with William McKinley in 1900." ${ }^{197}$ Kennedy himself was quick to realise he could not win the election in November without him. That does not mean resentments over the choice did not linger, with

"[s]ome Northern Democrats [being] dismayed, thinking JFK had betrayed his liberal principles by picking Johnson, but Kennedy adviser John Kenneth Galbraith told them facetiously: 'This is the kind of political expedient Franklin Roosevelt would never have used - except in the case of Nance Garner." "198

In direct contrast to the Democratic field, the battleground was not crowded for the Republican nominee. Richard Nixon was the front runner, but he had taken an entirely different journey to Kennedy over the last eight years.

Nixon had been in the public eye for many years but most recently (for eight years) as vice president to Eisenhower. Eisenhower himself was extremely popular but that popularity did not directly extend to the Republican Party. Tellingly, "[i]n 1958, the GOP received just 43 percent of the congressional vote, the lowest Republican tally since the Depression. By the decade's end, Republicans claimed only fourteen of the forty-eight governorships and held majorities in only seven state legislatures."199

\footnotetext{
195 Ibid, p. 853.

196 Recent literature on the role of Johnson in the campaign highlights his enormous influence in securing the 1960 election victory. See: Donaldson, The First Modern Campaign, pp. 133-137; Rorabaugh, The Real Making of the President, pp. 134-139 and Kallina, Kennedy v. Nixon. The Presidential Election of 1960, pp. 131-132.

197 Rorabaugh, The Real Making of the President, p. 139.

198 Boller, Paul F. (1996). Presidential Campaigns. New York: Oxford University Press, pp. 296-297.

199 Coenen, The Election of 1960, p. 849.
} 
Despite this, Nixon was still coming to the election from a position of substantial advantage; according to Liebovich, Nixon had built a political power base unlike any other vice president in modern history. ${ }^{200}$ Now, a sitting vice president wanted to be the first in 124 years to succeed to the presidency without a death intervening. Nixon quickly got the Republican drive off to a good start by announcing that his running mate would be the ambassador to the United Nations, former senator Henry Cabot Lodge. He was a very well-known American who was recognised as an expert on foreign affairs. Moreover, "Lodge, grandson and namesake of the famous Republican senator ... was a moderately liberal New Englander who added weight to the Republican claim that their party was more fit to handle international crises than were the Democrats." 201 In his acceptance speech for the nomination Nixon uttered one of his best lines: "When Mr. Khrushchev says our grandchildren will live under Communism, let us say his grandchildren will live in freedom"202 and despite the later intervention of television into the competition, after the parties' "conventions, the polls placed Nixon slightly ahead of Kennedy."203

A significant proportion of the literature about the 1960 election centres on the four televised debates between the candidates. ${ }^{204}$ The first debate was held on September 26 in Chicago. In an analysis of that particular debate, among others, Liebovich sets out to question many of the assumptions made about that performance. The accepted wisdom follows this thread: Nixon lost the election because Americans thought more of Kennedy's performance on television; Nixon failed to use makeup and wore a light suit, fading into the background; surveys showed those that watched television thought

\footnotetext{
${ }^{200}$ Liebovich, The Press and the Modern Presidency, p. 7.

${ }^{201}$ Ibid, pp. 853-854.

202 Pietrusza, 1960 - LBJ vs. JFK vs. Nixon, p. 231.

203 Coenen, The Election of 1960, p. 854.

204 See: Donaldson, The First Modern Campaign; Kallina, The Presidential Election of 1960; Pietrusza, 1960 - LBJ vs. JFK vs. Nixon and Rorabaugh, The Real Making of the President. Also: Ellsworth, John W. (1965). Rationality and Campaigning: A Content Analysis of the 1960 Presidential Campaign Debates. Western Political Quarterly, 18(4), pp. 794-802.
} 
Kennedy had won, and those who heard the debate on the radio thought Nixon the victor; six percent of those polled as part of the exit polling said the debate "had been a deciding factor in their minds, and most ... had voted for Kennedy."205

Liebovich challenges these assertions. He is of the view that Kennedy in a dark suit contrasts with the background better, but in black and white the difference was negligible; Nixon was seen as himself, the make up argument seems a bit overstated; and the polling post debate was, in one case, a group of 400 in the New York metropolitan area - hardly an accurate cross-section of America; and lastly was the election just a continuation of the 1958 congressional elections trend?

In an interesting analysis of the work that went into setting up the debate, Self 206 confirms that Nixon, who initially told aides he would not debate, changed his mind to avoid his manhood being sullied. The article provides insights into the psychology at play and suggests Nixon refused make-up because when Kennedy had debated Humphrey in the primaries the Kennedy camp took advantage of Humphrey using make up to suggest he had put on a false face. The candidates agreed not to use notes and Nixon was unnerved when Kennedy appeared at a podium with pieces of paper, but Kennedy insisted if he was going to quote the vice president he would do so accurately.

Whether or not the television debates were crucial to the outcome remains in contention, but to assert that if it had not been for the first debate Nixon would have won the election is an assertion that discounts the effect of other factors that were of equal significance. ${ }^{207}$ In any event, Kennedy had directly dealt with the label of inexperience and youth by holding his own against the vice president. The polls seemed to confirm this, with "Gallup polls before the first debate [having] Nixon

\footnotetext{
${ }^{205}$ Liebovich, The Press and the Modern Presidency, p. 10.

${ }^{206}$ Self, John W. (2005). The First Debate over the Debates: How Kennedy and Nixon negotiated the 1960 Presidential Debates. Presidential Studies Quarterly, 35(2), p. 361.

${ }^{207}$ Not the least of which were the perceptions of the media. See: Kallina, The Presidential Election of 1960, p. 112.
} 
leading, 50 to 44 percent, [while] [a]fter the debate Kennedy ... [was] ahead, 49 to 46 percent." 208

Coenen outlines the campaign strategy of each candidate: Kennedy would concentrate his time on large electoral states such as Pennsylvania and Michigan (assuming Johnson would carry the South), while Nixon had made a pledge to visit all 50 states $^{209}$ - a plan with questionable merit given the distances and number of electoral votes some states carried. As each candidate campaigned, the question of religion soon emerged. In a bold move, Kennedy spoke to the Greater Houston Ministerial Association on September 12 to directly confront the question. Kennedy declared publicly, yet again, his belief in the separation of church and state. ${ }^{210}$

A new phenomenon was also occurring, with Kennedy being mobbed at nearly every stop: political image had entered the frame. Kennedy's momentum was building, and Nixon could have slowed it but he refused to use the Ike card. Nixon had never been personally close to Eisenhower and was nervous that bringing the President into the campaign might be seen as an admission he could not win alone, but Eisenhower was a huge draw card with coattails much longer then the Republican Party itself - again Nixon did not want his political "manhood" questioned. When Nixon played the vice presidential card during the campaign, suggesting many of his ideas had been adopted by the administration as policy, reporters asked Eisenhower at a press conference to give an example - to which he unhelpfully replied: "If you give me a week, I might think of one. ${ }^{211}$

The eventual emergence of Eisenhower in the last weeks of the campaign gave Nixon a lift. Nixon continued to be wary of courting the black vote, to avoid alienating the

\footnotetext{
208 Coenen, The Election of 1960, p. 857.

${ }^{209}$ Ibid, pp. 849-866.

210 See youtube video: President John F. Kennedy Speech to the Houston Ministerial Association. Retrieved from https://www.youtube.com/watch?v=ZmQCwXM9X6o

${ }^{211}$ Coenen, The Election of 1960, p. 858.
} 
South, while Kennedy went directly after it, playing a role in having Martin Luther King released from jail in October. That bold move would prove decisive in "Illinois and Michigan, two states with sizeable numbers of black votes."212

On the eve of the election the result was too close to call, but to state the election was full of voting irregularities is an understatement.

“Of nearly five million votes cast in Illinois, Kennedy's plurality stood at just 8,858, and most other states polled very close results. Nixon would have won an Electoral College victory had there been a reversal of less than 30,000 total votes in Illinois and Texas."213

Rumours of irregularities in Cook County, Illinois dogged the result for days after the campaign, and the view that votes for Nixon in Texas were thrown out contributed to an air of uncertainty regarding the legitimacy of the outcome.

"Nixon, a man for whom political power and the presidency meant everything, did not contest the election. He was still young and would live to fight another day. For the rest of his life, Nixon stood by what he told New York Herald Tribune reporter Earl Mazo, shortly after the election: 'The country can't afford the agony of a constitutional crisis, and I will not be a party to creating one, just to become president.' Nixon gracefully bowed out to preserve his future political prospects, and Kennedy assumed the presidency with a razor-thin mandate." 214

Before analysing the reaction of the candidates to the election and determining whether those choices were authentic there remains one question to consider - was the 1960 presidential election stolen from Nixon? Greenberg records that

"Even before Election Day, rumors circulated about fraud, especially in Chicago, where Mayor Richard Daley's machine was known for delivering whopping Democratic tallies by fair means and foul." 215

It appears in the analysis offered by Greenberg that Nixon's position was arrived at to avoid being labelled a 'sore loser'. Greenberg points out that although Nixon appeared to be rolling over, Republican Party Chairman Senator Thurston Morton launched bids for recounts and investigations in eleven states. Field checks were undertaken by Nixon aides in eight of those states and in Chicago another Nixon aide, Peter Flanigan,

\footnotetext{
212 Ibid.

213 Ibid.

${ }^{214}$ Ibid, p. 859.

${ }^{215}$ Greenberg, David. (2000). Was Nixon Robbed? The Legend of the Stolen 1960 Presidential Election. Slate, 16 October, p. 2.
} 
encouraged the creation of the Nixon Recount Committee in Chicago. ${ }^{216}$ In fact, the Republicans pressed hard and "[t]hey succeeded in obtaining recounts, empanelling grand juries, and involving U.S. attorneys and the FBI. Appeals were heard, claims evaluated, evidence weighed ... The results of it all were meager." ${ }^{217}$ (emphasis added).

Texas and Illinois ended up in court and after a federal judge refused to hear the matter based on a jurisdictional question, only Chicago remained as an issue. As noted earlier, Cook County was the focus of the alleged fraud. Somewhat embarrassingly, “... in 40 percent of the rechecked precincts, Nixon's vote was overcounted. Displeased, the Republicans took the case to federal court, only to have the judge dismiss the suits." 218 The State Board of Elections also rejected the petition.

That is not to say that all was above board; but history, when retelling the 1960 election, often leaves out the detail of the many decisions not to challenge the vote by various tribunals and courts. It seems the focus of discussion is always on Nixon's decision not to challenge the result for the sake of country and future career. He may not have done so directly, but his sanctioning of others to do so on his behalf paints his magnanimity in a different light.

When beginning an examination of each candidates' character Barber ${ }^{219}$ provides a framework for some introductory observations about the way Kennedy 'orientated himself toward life, not for the moment, but enduringly’.

Kennedy was an easy character, someone who reflected the best of what those around him wished to be. His sense of independence and optimism was forged through a lifelong balance of recognising the heavy hand of his father and the need to keep his

\footnotetext{
${ }^{216}$ Ibid, p. 3.

${ }^{217}$ Ibid.

${ }^{218}$ Ibid, p.4.

${ }^{219}$ Barber, The Presidential Character, p. 8.
} 
father from being seen as too influential on his actions and campaigns. He orientated himself towards an ideal of excellence, and demanded it of those around him, while having a healthy disdain for the traditional methodologies previously employed in political life. He had a firm sense of self. Against a background of being in a poor state of health through out his life, this enduring ability to project youth, vigour and enjoyment is an achievement in itself. His aloof ease with others shields a mature sense of legacy building and idealism that can only be sourced from natural but underinflated self-confidence.

The characteristics outlined reflect patterns in Kennedy's life of someone who refused to follow the rules (at school and by having his candidacy endorsed by the use of the primaries rather than party bosses). His character, style and world view in the Barber model was slightly detached - confirming the initial pattern in his life, and that of his families as outsiders, yet the style he used to engage with others was unique. It had "... an élan, a dash and flair, flowing out from the brave-young-candidate to his audiences. People saw in him what they wanted to." 220

In short, he had charisma. In that sense, he made sense 'in psychological terms'. Barber's model also allows Kennedy to be placed neatly as a candidate who had a style (or a choice for operating) that did include a use of rhetoric ("Ask not what your country..."), close informal dealing (no Chief of Staff and the Irish Mafia on the White House staff) and cogitation (constant awareness of legacy building and myth creation image management).

The model offered by Gardner ${ }^{221}$ in distinguishing between leaders and managers is relevant but the traits outlined as attributes of leadership add authenticity to the character traits shown by Kennedy in decision-making. The Gardner attributes, among others, ${ }^{222}$ included: physical vitality and stamina (in Kennedy's case - projected if not

\footnotetext{
${ }^{220}$ Ibid, p. 311.

${ }^{221}$ Gardner, On Leadership, pp. 14-16.

222 Ibid, pp. 48-54.
} 
actual); intelligence and judgment-in-action (historical and curiosity levels meet this test as does the pre-occupation of excellence in staffing - "the brightest and the best"); willingness to accept responsibility (Bay of Pigs); understanding of constituents and their needs (willingness to engage with the civil rights movement); skill in dealing with people (remaining aloof while not detached); need to achieve (first to space); confidence (self evident).

On these and other 'attribute' tests Kennedy meets the requirements in having the necessary traits and tendencies to assume a role of leadership, with a pattern of behaviours, already outlined, showing consistency in his approach to decision-making and behaviour. Interestingly, the ability of Kennedy to persuade was probably one of his strongest suits (the Peace Corps being an example). His use of rhetoric as a tool to influence and persuade is noteworthy.

Burns $^{223}$ presents two factors for consideration which reinforce this model of authenticity in the case of Kennedy. Motive and resource as two key ingredients for power are present. Resource (money, people and energy) is present while motive is more complex. The issue of gaining respectability for Kennedy and his family was thoroughly canvassed in chapter 3 of this thesis, as was the psychological need to strive for greatness (at the insistence of his father) following the death of Kennedy's brother and sister. This does not, however, undermine the authentic nature of his participation in politics, nor diminish his own ambition. As noted, it was clear Kennedy had been developing an interest in both domestic and international affairs long before the death of his brother.

The issue of motive is met by Kennedy. Reeves sets out the view of historian Arthur Schlesinger, Jr., who framed Kennedy as "... a man of principle, consistency, and selfconfidence". He was "an exceptionally cerebral figure," "a committed liberal" who

\footnotetext{
${ }^{223}$ Burns, Leadership, p. 12.
} 
admired intellectuals and would turn to them for advice. Nixon was in the ... race for private gratification ..."224

Again, against the Barber model, initial construction of Kennedy's character seems to confirm that a consistency of traits is present. While Barber was determined to categorise presidential character into four areas, there is merit in using those 'characterisation models' on each of the candidates before they held such high office. Kennedy fits within the framework offered by Barber as an "active-positive" in that there is an abundance of activity and an enjoyment of it. This includes seeing positive value in productivity as something to aspire to. This model has the president (candidate) seeing themselves "as developing over time toward relatively well defined personal goals"225; rational mastery plays a key role here, but in essence the subject sees himself "growing toward his image of himself as he might yet be."226

Kennedy was always cognisant of the need to project positivity, to revel in the job, and he seemed to naturally enjoy it. ${ }^{227}$ An impatient curiosity was present in Kennedy and while vitality as a physical domain may have been an image projected, it was a state of mind. The adventure to space, the Peace Corps and the seeds of a civil rights revolution indicate Kennedy looked to the stars in wanting to achieve results, using rhetoric to articulate these lofty goals. Kennedy prided himself on his rational approach to decision-making, discarding emotional advice as being contrary to the image of toughness and excellence he wished to promote, seeing himself as being at the centre of a group of intellectual men who would, in historic terms, be highly regarded for the quality of the choices they made.

\footnotetext{
${ }^{224}$ Reeves, A Question of Character, p. 215.

225 Barber, The Presidential Character, p. 12.

226 Ibid.

227 See Kennedy's Inaugural Address, with these words in particular: "I do not shrink from this responsibility - I welcome it."
} 
Neustadt concentrates on persuasion as a key factor in determining a genuine grasp of power and leadership. ${ }^{228}$ Neustadt - who published Presidential Power in 1960 and met with Kennedy - maintains that Kennedy as a president had an operating style that lent itself to employing characteristics which included "... the personal command post, a deliberate reaching down for the details, hard questioning of the alternatives, a drive to protect options from foreclosure by sheer urgency or by ex-parte advocacy, and finally a close watch on follow through." 229

Kennedy's use of far reaching rhetoric and idealism as a catch-all was designed to persuade a new generation that politics needed to be viewed through a different lens. This reinforces the model of active-positive, suggested by Barber.

Kennedy fares less convincingly when analysed though the more specific requirements set out by Hargrove ${ }^{230}$ in attaining authenticity.

On the matter of cultural leadership, Kennedy displayed (before 1961) a sense of the balance between purpose and prudence. The manner in which Kennedy selected a vice-presidential running mate provides a useful case study on this point. Knowing the liberal elements of the party would be disappointed with a selection of Johnson as running mate did not stop Kennedy choosing a running mate who would hold the Southern vote. Electoral prudence and purpose aligned in the decision to place Johnson on the ticket.

On the issue of teaching reality, Kennedy believed in a world view that would appeal to the idealism he shared with America. He took tentative steps toward a civil rights movement in 1960, rather than using the demographics of divisive politics to achieve victory. He stood for something and tried to sell his view rather than merely appealing to the darker side of the voters' suspicions and prejudices.

\footnotetext{
228 Neustadt, Presidential Power and the Modern Presidents, p. 11.

${ }^{229}$ Ibid, p. 172.

${ }^{230}$ Hargrove, The President as Leader, pp. 25-52.
} 
The last factor in the Hargrove model is the factor of skill. This is a more difficult hurdle for Kennedy. While he may have had the necessary psychological health and mental toughness to do the job, his physical health cannot have contributed to the level of stability needed in this sub-category. This recklessness, in assessing character, is directly linked to integrity. Kennedy's risk taking in his personal life informs the componentry of integrity and moral commitment. His ability to meet this criterion is compromised.

Lastly, Renshon suggests three foundations of character. The first is ambition, the pursuit of goals and the realisation of values. This factor is satisfied by drive and determination - Kennedy meets this basic requirement. He campaigned cleverly and with purpose right through $1958-1960 .{ }^{231} \mathrm{He}$ kept rigidly to a timetable set by his family well before 1960 and did not deviate from that plan (excepting the decision to run for the vice-presidential ticket in 1956). Indeed, in the life of John F. Kennedy the attention of his family, and in particular his father, was the foundation of that ambition.

The second foundation of integrity is the character domain from where a candidate's ideals are realised. Renshon considers it the place from where self-esteem stems. As noted, in the Hargrove model integrity was not completely fulfilled, but within the Renshon framework a different context is applied. Kennedy certainly consolidated his ideals through extensive use of rhetoric challenging the American people to look at their relationship with government differently. Within that sub-set of authenticity Kennedy fulfilled both the capacity to endure loss and a degree of separateness from others - criteria he fulfilled under other theoretical models as well. In essence Kennedy worked hard (to use Renshon's test) to be the person he saw himself to be and the person he appeared to be.

\footnotetext{
${ }^{231}$ The deliberate and calculating way this was carried out is detailed in Oliphant \& Wilkie, The Road to Camelot; Inside JFK's five-year campaign.
} 
Finally, the element of relatedness is present. In this sphere others moved towards Kennedy - from the time he was at school, through Harvard, as a PT Captain and as a Congressman and Senator.

On display were cognitive elements indicating an early interest in history and foreign affairs. His problem-solving technique and operating style were detailed by Neustadt and fit with a cognitive capacity. Making public his view that he had surrounded himself with the brightest and the best aided this view, together with the capacity to persuade - an example being the way he directly confronted the issue of religion during the 1960 campaign. Lastly, he exhibited self-belief. His ability to navigate the issues of religion, the control of his father and the death of his siblings show a capacity to overcome hurdles and hardships.

Those decisions Kennedy made - relating to his choice of running mate; dealing with the issue of religion; knowing when to keep his father in the background; gambling on the primary elections rather than seeking the approval of party bosses; confidently relying on the success of televised debates; choosing idealism as a teaching reality and believing in the positive attributes of Americans - all fit within the parameters of the theoretical models of character designed to test whether the decisions and choices Kennedy made on his way to the White House were authentic. The patterns of behaviour, the very events that shaped him, stood consistently with his most recent choices. Even applied situationally, there emerges a consistency to the application of character traits and on most measures, Kennedy meets the test of authenticity.

An examination of the authentic nature of the character of Richard M. Nixon is a vexing proposition.

Chapter 4 sets out the battles, disappointments and tragedies he endured. He had convinced himself that he could achieve his goals by sheer force of will and determination. He forced himself into situations in which he was not comfortable; he would become battle-hardened and unafraid of large scale conflict. Although better in 
front of crowds than one on one, he modelled himself as an outsider capable of representing the views of those who had no voice.

In the cases of both Jerry Voorhis and Helen Gahagan Douglas he seemed to genuinely regret the course of action he had taken - but only admitted so once he had won. Nixon was a battler, but he was also a divider and a loather of others whose lives had followed an easier path than his. He was capable of brilliance (China and Checkers) and of deep human frailty (Watergate), but regardless of his well documented complexity, there was one trait of his character that was deeply embedded in his psyche, from birth to the loss of the 1960 presidential election - he was not a quitter.

Using the theoretical frameworks outlined in chapter 2 - how did the decisions Nixon made and the behaviour he displayed up until 1960 exhibit the authentic nature of his character?

Barber's definition of character provides a useful starting point; he defines character as 'the way the ... [individual] ... orients himself towards life - not for the moment, but enduringly. Character is the person's stance as he confronts experience.' In that sense, Nixon saw himself as a battler against the establishment. The establishment to Nixon was not just the north-eastern privileged but anyone who had enjoyed the opportunities he had not. Enduringly Nixon would continually confront his own duality: between the achiever and the tortured outsider.

The pattern, in Barber's model, that Nixon had set for himself showed him to have a steely determination to succeed (as he had at school and college) - to win at all costs. This pattern, driven by a sense of disadvantage and guilt (following the death of two of his brothers), would manifest in his decision to overreach in pledging to visit all 50 states in the lead-up to the 1960 election.

His style, rather than his "stylishness", was introverted yet could be brilliantly clever. The way he operated may not have involved use of high rhetoric but his use of plain 
language (as was used in the Checkers speech - "a cloth coat", "I am not a quitter") was in many cases just as compelling in reaching an untapped audience. ${ }^{232}$ His close informal dealing was done through a few trusted advisers, particularly during campaigns, but his style was to make his own mind up. Nixon did not brainstorm - he issued directives, used memos and often referred to himself in the third person. He trusted his own thoughts and did not need friendship to mandate the course of action he was taking - he would rather earn respect than love.

Under the Gardner model the attributes Nixon displayed confirm this picture of selfreliance and private solitude. He certainly had stamina (the long hours of study at school and college he would put in to succeed); there was no question of his task competence (winning a Harvard scholarship and setting up alternate fraternities to the ones he was not invited to join); he had a need to achieve (finishing high in his class at college; the youngest member of the Senate when he was first elected); and a capacity to manage, decide, assert and dominate (his dissection of Hiss), meaning many of the necessary attributes manifested themselves in this construct.

Although many of these traits would continue to develop, the nature of the early influences on Nixon were undeniably present - confirming his character as consistent and authentic at many junctures.

Burns identifies two essential ingredients for power, in a leadership paradigm, as motive and resource. There is no disputing Nixon had motive. From entering politics in 1946, he was vice-president of the United States by 1953 - there is no doubting his drive. The issue of resource is not present. If resource is defined as personal capacity then the requirement is met, but if it relates to physical resource - to money - Nixon was very much his own man, at least until his run for the Senate. He ultimately understood such a resource was required. Specifically, in 1960, he had the luxury of

\footnotetext{
${ }^{232}$ It is significant that he was reaching a different audience - "the middle-class values of the suburbs, small towns and countryside of America." See Kallina, Kennedy v. Nixon, p. 112.
} 
being able to seek the nomination as a sitting vice-president, a position that brought with it huge advantages.

In examining the four character baselines offered by Barber, the character Nixon resembles is the 'active-negative' model. The model is explained by Barber:

\begin{abstract}
"The contradiction here is between relatively intense effort and relatively low emotional reward for that effort. The activity has a compulsive quality, as if the man were trying to make up for something or to escape from anxiety into hard work. He seems ambitious, striving upward and seeking power. His stance towards the environment is aggressive ... [1]ife is a hard struggle to achieve and hold power, hampered by the condemnations of a perfectionist conscience. Active-negative types pour energy into the political system, but it is an energy distorted from within." 233
\end{abstract}

For Nixon "[i]ndependence, intense preparation, and public performing became the habits of his political life." 234

The root of the 'two Nixons' can largely be put down to the influence of his parents. Nixon had to balance the natural debater who was the acceptable face of aggression from his father, and the scholar, the battler and the underdog that was his mother. Both these Nixons found an outlet in politics. The childhood influences described by Bennis $^{235}$ could not, and were not, overcome as influences in adult life.

The extent to which Neustadt emphasised temperament informs an analysis of Nixon. Tenacity and determination were qualities Nixon possessed but Neustadt is more interested in 'drivenness' as a trait and the way a contender reacts to frustration indeed 'striking out succeeded by a closing in'236 describes a Nixon reaction perfectly. The accusations of secret funds being used by Nixon, followed by an inward-looking determination to overcome, and intense preparation - alone, planning, a striking out at Eisenhower for not supporting him, a stunning public performance and then turning inwards, resentful and scheming.

\footnotetext{
${ }^{233}$ Barber, (fourth edn.), The Presidential Character, p. 9.

${ }^{234}$ Ibid, p. 142.

235 Bennis, On Becoming a Leader, pp. 61-62.

${ }^{236}$ Neustadt, Presidential Power and the Modern Presidents, p. 205.
} 
The model offered by Hargrove presents three elements - skill, cultural leadership and teaching reality. In the skill category Nixon met the criterion of moral commitment to the cause. His intent was to empower those who had no voice (including himself) and that indicates a genuine purpose regardless of how he achieved it. His psychological health was a more complex matter but while the balance of the two competing influences (of his mother and father) were on an even keel, it is fair to suggest the results for Nixon up to 1960 were delivered with the requisite degree of skill.

Integrity as a prerequisite in confirming authenticity of character is not met. In defeating Voorhis and Douglas by labelling them communists, Nixon revealed a side to his personality that the public saw more of in his last months in the White House. He knew, and later admitted, that he had treated both unfairly (indicating some integrity), yet only admitted to such regret when he had won. He may have won without employing such tactics, just as he did in 1948.

Nixon does score well on the second limb of the model - cultural leadership. He was able to balance purpose with prudence. All the way through his years as vice-president, he acted with calculated prudence, knowing he may need Eisenhower in 1960.

The limb of the teaching reality is perhaps the most informative element. Did Nixon, as Hargrove would put it, '... contribute to the quality of political discourse in the polity? ${ }^{237}$ Nixon was hardly an idealist. He was a realist. He simplified and controlled as a teacher, and as a preacher he appealed to the darker angels of the polity by calling on the so-called 'silent majority'- those anti-liberal, patriots who were sick of lawlessness and long hair. Seeking particular demographic groupings' support for a political cause is hardly a moral negative, but for Nixon it appeared there was no high ground for a better world. It is difficult to ascertain exactly what Nixon believed. He reflected a view rather than espoused one.

\footnotetext{
${ }^{237}$ Hargrove, The President as Leader, p. 42.
} 
All that skill, energy and tenacity; the tendency to work problems out on his own, the independence of background and the ordinary childhood; the rapid rise in politics - all that promise with no end point except power for its own sake. This assessment confirms the active-negative model offered by Barber.

Renshon, as noted, offers three character domains for exploration - ambition, integrity and relatedness. Nixon meets the ambition test. He displays throughout his life the qualities of tenacity, drive, and fierce determination. His mother's view of him was the building block for his achievements in this regard and represents all that is good in Nixon's mind. Integrity is not so easily fulfilled. As noted in chapter 2, Renshon sums it up as follows: “... a person may have developed and redefined his or her ideals and values but lack the capacity to realize them in a manner that maintains fidelity to them." 238

This is framing easily applied to Nixon. Whilst his genuine belief may have been to give a voice to those who are generally ignored in the political conversation, this goal was ultimately lost because of the part of Nixon's character that came from his father. His insecurities were driven by the guilt he felt at the death of his brothers and the parting from his father confirming his desperate quest for independence. Ultimately these character traits would outweigh those that were designed to see out a set of ideals. In Renshon's model Nixon 'had failed to consolidate his ideals ... ultimately undermining the development of his sense of authenticity'.

Within that framework Nixon did, however, meet other criteria. He had a capacity to endure loss - not just personal loss like the death of his brothers, but deep personal disappointment like the family having no means of allowing him to take up his hardearned scholarship to Harvard. He was able to endure conflict - such as staring down his accusers with the Checkers speech. He also had a degree of separateness from others: he was a loner. The only glaring exception to this trend was his time in the

\footnotetext{
${ }^{238}$ Renshon, The Psychological Assessment of Presidential Candidates, p. 188.
} 
Navy, where he learned to play poker. In the final analysis there was too much distance between how Nixon saw himself and the person he really was.

The third part of the foundation outlined by Renshon is relatedness. Nixon essentially moved away from or against people. That was how he built his name and gained the limelight on the national stage so early in his career. Although the 1948 congressional elections saw him move away from this model and still win comfortably, Nixon took this option then because he knew he was playing from a position of advantage. When he was involved in the hand-to-hand combat of close political contests he reverted to type - aggressive and domineering, a skilled debater who used those skills to destroy others rather than lead a debate of worthy ideas. His capacity to conduct enduring interpersonal connections was minimal. He was respected as a young man and at school - not liked. People were not drawn to his orbit, they feared him and were in awe of capacity to work and succeed.

The last part of the Renshon framework is that of character-style. Nixon's characterstyle was detailed and analytical. His time was spent gathering information to apply to the detriment of others - Hiss and forming alternative fraternities at college highlight this approach. His body language and mannerisms gave weight to the view that he was readying himself for another battle, another chance to prove his independence. His interpersonal abilities were present but not fully utilised. He intrigued people and they admired his drive and respected his success, but he was never affectionately regarded and tended to move away from relationships that were not able to further his political advancement.

Finally, Nixon had a characterological element of total self-belief. He relied on no one and had no hesitation in taking the initiative without external approval. He could objectively be given credit for sustaining resilience from setbacks and overcoming adverse circumstances through total focus and self-reliance. 
Nixon interestingly displayed authenticity in character at various points in his life dealing with the death of his brothers; working even harder at Whittier College when unable to attend Harvard; beating Voorhis with tricks and propaganda and immense hard work; destroying Alger Hiss with a sole focus on collecting detailed information about his past; finishing the career of Helen Gahagan Douglas to advance his own; and off the back of that determined but dark approach to leadership, he secured the nomination of the vice-presidency after a scandal that would have finished anyone else off in politics. The Checkers speech was vintage Nixon. Come out swinging - the underdog, the battler, demanding again independence, this time not from his father but from Eisenhower and the Republican Party hierarchy. Cleverly appealing straight over Eisenhower's head directly to the public, who, until now, had never had a say in such weighty matters. These were all examples of Nixon at his most pure, most authentic.

The way he conducted himself during the 1960 election, including the immediate aftermath, sullied this consistency of character. The debates saw a restrained and edgy Nixon, one who was not natural against the charming and well-presented Kennedy. It is the contention of this thesis that had Nixon allowed his 'real self' to appear in those debates, those small differences between himself and Kennedy would have been immaterial. Had Nixon come out fighting, aggressive and determined, the population watching would have seen a masterful Nixon, cognisant of the facts under discussion and bruising when highlighting the depth of his experience and knowledge compared to his opponent's lightweight approach. But he allowed himself to be intimidated. The Nixon of Checkers fame would have been determined to wound his adversary immediately. That Nixon may not have used rhetoric, but plain clear language the electorate would have understood and related to. That Nixon would have appealed to every battler watching. He would have appeared a bit bruised, not as polished as Kennedy, but his was not a life of privilege and opportunity - nor were the lives of those watching. His approach of trying to compete with Kennedy on his terms, and allowing Kennedy to determine the ground rules for the debate, was not authentic. 
The result of the 1960 election and Nixon's reaction has been covered earlier in the chapter. What this thesis contends is that Nixon's famous response of not causing the country grief through challenging the outcome in 1960 was far from authentic. It was not an authentic character response on two levels. First, he did challenge the result. He may not have done so himself, but he almost certainly sanctioned the actions of those who took claims in many states over alleged irregularities. To state he was more concerned with maintaining the integrity of the process was not genuine, let alone authentic. Secondly, the authentic Nixon (described above) would have fought. He would have fought as he had in so many other circumstances in his life. Nixon backed into a corner would have doubled his efforts, worked even harder. He would have picked the results apart over time, destroying the case of the Democrats as he had the career of Hiss.

In only one sense can his reaction be described as even honest, and that was the decision he made to not further damage his political prospects. Hargrove would contend, no doubt, that Nixon allowed prudence to overcome purpose, but that was not the Nixon of 1913-1960. His response to the result of the 1960 election was not authentic. 


\section{CHAPTER SIX:}

\section{GORE}

Al Gore Jr. was born on March 31, 1948. The "Jr." is significant because it was initially precious to Gore but later abandoned when it was no longer considered advantageous. Whereas Bill Clinton has been described as "the natural", ${ }^{239}$ the best phrase to describe Gore, is "the unnatural". He has been described variously as "the wooden Apollo", ${ }^{240}$ as having "a very tight rubber-band tied around his waist", ${ }^{241}$ and someone who now and "... then as always, ... tried not to disappoint." 242 Gore was born into a family of political privilege. His father had been in public service for thirty-two years, latterly as a US Senator. As Albert Gore Sr. (Gore Sr.) walked the corridors of the Capitol he could be heard yelling to his small son: "Keep Up, son! Keep Up". ${ }^{243}$

Gore was not a southern boy, and despite claiming Carthage, Tennessee as home, he was born in Washington D.C. and raised largely in the top floor suite of a hotel along Embassy Row. When he arrived into the world his father told a Washington reporter for the Nashville Tennessean "“[i]f I have a baby boy, I don't want it buried on the inside of the paper. I want it on Page 1 where it belongs.' He got his wish."244

However, it was Gore's mother, Pauline La Fon, who had the biggest influence on him. She was brave and bright and met Gore Sr. when she was a waitress. As one former Tennessee journalist described it, "Pauline was the brains and Albert was the pretty

239 Klein, Joe. (2002). The Natural: The Misunderstood Presidency of Bill Clinton. New York: Broadway Books.

${ }^{240}$ Moraniss, David and Nakashima, Ellen. (2000). The Prince of Tennessee: The Rise of Al Gore. New York: Simon and Schuster, p. 64.

${ }^{241}$ Zelnick, Bob. (1999). Gore: A Political Life. Washington DC: Regency, p. 42.

242 Turque, Bill. (2000). Inventing Al Gore. New York: Houghton Mifflin, p. 1.

${ }^{243}$ Moraniss and Nakashima, The Prince of Tennessee, p. 20.

${ }^{244}$ Zelnick, Gore: A Political Life, p. 27. 
blond." 245 She enrolled at Vanderbilt Law School, where she became only the tenth female to graduate, and she encouraged Gore Sr. to run for the Senate in 1952.

He ran against Kenneth D. McKellar who had been in the Senate thirty-five years. Hoardings for McKellar read "Thinking Feller Vote for McKellar" while Gore Sr. countered "Think Some More \& Vote for Gore". ${ }^{246}$ Gore Sr. continued that level of bravery and conviction onto the Senate floor. He

“... stood against the war in Vietnam, was a prime architect of the ABM Treaty ... and a proponent of the comprehensive Test Ban Treaty [and] he did tell Strom Thurmond to shove it when the latter approached him on the floor of the Senate with his Southern Manifesto, calling on the states to resist court-ordered demands for desegregation." 247

Gore was born into a world where his destiny was already mapped out. He followed his older sister Nancy, whom he adored, into the world, and he would later use her death from lung cancer to give a very personal speech about the tobacco industry. Nancy was the real politician in the family, easy-going with great courage and very like her mother.

Gore's life was inextricably linked to his father's expectations, as Bossie and Brown state: “Albert Arnold Gore, Sr. (1907-1998) cast a giant shadow over his son's life. It is impossible to understand the son without understanding his father."248 Pompous but principled, ${ }^{249}$ Gore Sr. started his working life as a superintendent of schools and never lost the demeanour. However, the elected Gore Sr. lost track of two important factors in his home state of Tennessee. The first was the rise of the Republican "Southern strategy"; the second was that his constituents began to see his anti-segregationist tendencies as the views of someone who had transformed into an Eastern liberal. This image was capitalised on by Republican Bill Brock in 1970, when he defeated Gore (a three term Senator) by portraying him "as an out-of-touch liberal opposed to God,

\footnotetext{
${ }^{245}$ Moraniss and Nakashima, The Prince of Tennessee, p. 30.

246 Ibid, p. 33.

247 Cockburn, Alexander and St Clair, Jeffrey. (2000). Al Gore: A User's Manual. New York: Verso, p. 2.

${ }^{248}$ Bossie, David and Brown, Floyd. (2000). Prince Albert: The Life \& Lies of Al Gore. Washington: Merril Press, p. 7.

${ }^{249}$ Moraniss and Nakashima, The Prince of Tennessee, pp. 24-25.
} 
family, and the Tennessee way." ${ }^{250}$ Tellingly, "[that] defeat ... taught the younger Gore an unforgettable lesson, one that he would follow six years later: that he should never venture too far from the center or from his constituents." 251

Gore would learn from his father's loss the hard political consequences of not being all things to all people. Gore acknowledged this when he wrote:

"I grew up in a determinedly political family, in which I learned at an early age to be very sensitive - too sensitive, perhaps - to what others were thinking, and to notice carefully maybe too carefully - the similarities and differences between my way of thinking and that of the society around me." 252

As a child Gore has been described repeatedly as 'earnest', but his was not an ordinary upbringing. Gore lived half a life in Washington D.C. and half a life in the holidays in Carthage, Tennessee where he was required to work the fields on the family farm to teach him a sturdy work ethic. In his final year in high school he would come second in an election for senior prefect. His opponent had a little more talent and a little more charisma, ${ }^{253}$ consigning Gore to the role of runner-up. At his senior prom, he met Mary Elizabeth Aitcheson - 'Tipper'. She was full of life and endured politics rather than enjoyed it. She was just what Gore needed to alleviate the woodenness.

For Gore, Vietnam represented a crossroads; he believed the war was wrong but did serve for a few months as a combat journalist. The decision was one which revealed Gore's first compromise. Gore Sr. disapproved of the war but was now struggling in the Senate and "if ... Gore tried to avoid the draft, he could hurt his father's chances for re-election." ${ }^{254}$ His experience of Vietnam was not like that of most Americans; although Gore did enlist before he was drafted, "some of those who served with Gore say his experience was closer in spirit to Good Morning, Vietnam than Platoon."255

\footnotetext{
${ }^{250}$ Ibid, p. 113.

${ }^{251}$ Ibid, pp. 113-114.

${ }^{252}$ Lemann, Nicholas. (2000). Gore Without a Script - What Would Happen If We Saw The Man He Really Is? The New Yorker, 31 July, p. 46.

${ }^{253}$ Morannis and Nakashima, The Prince of Tennessee, p. 60.

254 Stefoff, Rebecca. (1999). Al Gore: Vice President. Connecticut: Milbrook Press, p. 20.

255 Turque, Inventing Al Gore, p. 87.
} 
Gore's decision, which appeared principled, was not, with "those around him at the time [feeling] that volunteering for Vietnam was also a way of holding the door open for his own political aspirations." ${ }^{256}$ In fact, General Westmoreland - Chief of Staff of the US Army - arranged for Gore to be an army journalist during the war, ${ }^{257}$ and was savvy enough to comprehend that "... Senator Albert Gore, Sr. was a bitter critic of the Vietnam War. The last thing the beleaguered Army bureaucracy wanted was to get the only son of a senior U.S. Senator killed in Vietnam."258

Behind Gore's attitude to Vietnam was the influence of his tutor at Harvard, Richard E. Neustadt. During the time Gore anguished over Vietnam, Neustadt acted as a sounding board for him. Neustadt remembers putting the argument that "if you want to be part of the country twenty-five years from now, if you want any future in politics, you've got to serve." ${ }^{259}$ During one of the conversations Gore is said to have told Neustadt that he felt he "... had to do what his father's constituents had to do." 260

Politically, Gore had outwardly shown strength and pragmatism, but as a measure of character, had failed a test of authenticity.

When in 1970 Gore Sr. lost his Senate seat it would directly inform the way Gore practiced politics, ensuring he never strayed too far from the centre; it would also require him to change who he was: how he spoke and how he conducted himself, depending on whether he was in Washington or at home in Tennessee. His dilemma is contextualised by Bossie and Brown, in that "his Tennessee friends observed with amusement how he compartmentalised his different lives in Carthage and D.C. He

\footnotetext{
${ }^{256}$ Ibid, p. 72.

${ }^{257}$ Cockburn and St Clair, Al Gore: A User's Manual, p. 25.

258 Bossie and Brown, Prince Albert, p. 35.

${ }^{259}$ Morannis and Nakashima, The Prince of Tennessee, p. 106.

${ }^{260}$ Ibid, p. 109.
} 
shed his Tennessee accent and country way of walking as he returned Inside the Beltway."261

After Gore had spent six months in Vietnam he returned to be a journalist at the Nashville Tennessean. He then dropped out of the religion programme at Vanderbilt University and in the fall of 1974 he enrolled at Vanderbilt Law School. John Seigenthaler, Gore's editor at the Tennessean, phoned him in the Spring of 1976 to advise him that Joe L. Evins, the long standing Democratic representative from Tennessee's fourth district, would announce his retirement - from the very seat once held by Gore Sr. So at 28 years of age, Gore dropped out of law school to run. He then faced the first dilemma of his candidacy: should he allow his father to campaign for him? In a move that would foreshadow the way he treated Clinton in 2000 Gore elected to run alone.

One of the most telling descriptions of how Gore weighed whether the electoral influence of his father was positive or negative came from a long-time political backer of Gore's father. Walter King Robinson, when told of Gore's decision to tell his father to stay away - that he didn't want to be elected as Albert Gore's son - is said to have remarked caustically, “... son, that's probably the only reason they will vote for you."262 His father understood Gore's need to run solo and did not make any speeches during his son's first campaign. With Gore's name recognition approaching 90\%, his first campaign was the only close race he ever ran in Tennessee. Gore won by 3,500 votes out of 115,000 votes cast. There was no Republican opposition, just an independent, and "on January 4, 1977, Al Gore stood on the floor of the House of Representatives and raised his right hand to become a member of the 95th Congress, reclaiming the seat his father had first won thirty-nine years earlier."263

\footnotetext{
${ }^{261}$ Bossie and Brown, Prince Albert, p. 24.

262 Cockburn and St Clair, Al Gore: A User's Manual, p. 49.

263 Turque, Inventing Al Gore, p. 130.
} 
Gore was a hard-working and committed Congressman, but soon had his sights set on the US Senate. In early 1983, Howard Baker, a sitting Senator in Tennessee, announced that he would not seek re-election. After eight years in the House and a solid reputation, Gore was ready for the step up at only 36 years old.

In 1984 his sister Nancy was diagnosed with lung cancer and within a year would die. The literature on Gore consistently refers to this period in his life and one other (an accident involving his son) as defining moments. The death of his sister contributed directly to his psychological makeup and ignited a campaign by Gore against big tobacco. It was the first sign Gore was prepared to stand not just for something, but also against something. In Chicago, at the 1996 Democratic National Convention, he made a speech about Nancy and the tobacco industry. It was not well received: “... Gore used his sister's death in his operatic denunciation of smoking with full knowledge that he had grown tobacco, courted tobacco growers and remained throughout his political career a staunch defender of government subsidies for the cash crop". 264

While he could appear electorally unprincipled, Gore appears to have a deep emotional reservoir which manifests itself only occasionally, and it is arguably a step too far to describe him as intentionally manipulative or devious. While he exaggerated from time to time, it seems incompatible with his character for Gore to have purposefully exploited the death of someone he cared so deeply for.

Gore won his 1984 race for the US Senate but was not welcomed with open arms by the old club, with judgments of Gore following a consistent premise: from the South but raised in the Northeast. "In a body where nearly all ninety-nine other members looked in their bathroom mirror on at least one morning and saw a potential president, Gore's young-man-in-a-hurry manner often grated."265

\footnotetext{
${ }^{264}$ Saunders, Debra. (2000). The World According to Gore. San Francisco: Encounter, p. 5.

${ }^{265}$ Turque, Inventing Al Gore, p. 165.
} 
After only two years in the Senate, Gore entered the 1987 primary race for the presidency. He had formed the view that he was the John Kennedy of his generation and in the spring of 1987, in the same Senate caucus room Kennedy had used in 1960, he declared he would run. At this stage of his political career Gore had virtually no influence or networks beyond his home state of Tennessee and had not yet completed half of his first term as a Senator. ${ }^{266}$ Although in his mind he had been groomed from birth to be President, the candidate simply did not endear himself to people. The media were also starting to form views of Gore that he would be unable to shake for the rest of his political life: "It was during the campaign that what became a clichéd gag about Gore gained currency: How can you tell Al Gore from the secret service agents guarding him? He's the stiff one."267 During the primary campaign he could not connect with voters, leading him to overcompensate as he simultaneously tried to appeal to the hawks in the post-Reagan environment; Dixiecrats from the South; environmentalists; and farmers. In the primaries in New Hampshire he was fifth with only $7 \%$ of the vote and although he picked up North Carolina, Tennessee, Kentucky, Arkansas and Oklahoma it was too late and further, he had exaggerated to overcompensate by claiming, "I'm the only farmer in this race." 268 Jim O'Hara, who was covering the Gore campaign for the Tennessean, noticed that Gore kept changing his answers depending on the audience. ${ }^{269}$ This coupled with historic observations about his location-dependent accent reveal a lot about the pre-2000 Gore. He knew who he was but wasn't sure if others would like that version of him, so he morphed into what he thought they expected him to be.

At age 40, Gore was a failed presidential candidate half way through his first term in the Senate when further tragedy struck. In April 1989, his son, Albert Gore III, was hit

\footnotetext{
${ }^{266}$ Moraniss and Nakashima, The Prince of Tennessee, p. 207.

267 Zelnick, Gore: A Political Life, p. 156.

${ }^{268}$ Morannis and Nakashima, The Prince of Tennessee, p. 223.

${ }^{269}$ Ibid, p. 226.
} 
by a car. ${ }^{270} \mathrm{He}$ was seriously injured and nearly died. It was at this point Gore made the decision not to run for either spot on the presidential ticket in 1992.

"Gore mythology has it that seeing his son hit by an automobile after a baseball game in 1989 helped him decide not to run for President again in 1992. Although his son's accident was a searing experience and Gore devoted himself completely to the child's recovery, it's also the case that at the time he turned in the first draft of the book he still hadn't made up his mind about 1992. (By his own account he began writing the book in his son's hospital room)."271

The book was Earth in the Balance. At his most vulnerable, he began to think about what was important and no doubt, as on the death of his sister, the tragedy afforded him the moments to assess what really mattered to him. The real Gore was momentarily revealed. Unlike the decision to go to Vietnam, and the advice from Neustadt that his future required him to serve, Gore was free of the expectations of others. What was produced by Gore was instructive in that "Earth in the Balance is the essential Gore: thoughtful, earnest, ambitious, crammed with facts, moralizing, hyperbolic, and breathtakingly grandiose". ${ }^{272}$

Although during this time Gore was successfully re-elected to the Senate, in 1990, he did so whilst completing his book. Gore re-balanced his life and put his family first. It was not just his decision not to run in 1992; his family, in particular Tipper, were adamant he would not. After the challenges and disappointments of 1988, Earth in the Balance was a cathartic experience for Gore. It was a statement to himself that he was capable of forming his own views and of knowing his own mind. Indeed, as one article describes the process, he was in need of spiritual redemption. ${ }^{273}$ In an ironic twist, the publishing of his book did not take him away from Presidential politics at all. It had the opposite effect: it dragged him back into the sunlight in January 1992.

Following the Democratic Leadership Council in May 1991, where both Gore and Clinton spoke, Clinton began to look at Gore as a vice-presidential prospect. Gore's prospects for the role were certainly enhanced by the refusal of others to get on the

\footnotetext{
270 Zelnick, Gore: A Political Life, pp. 168-170.

${ }^{271}$ Lemann, Gore Without a Script, p. 54.

272 Turque, Inventing Al Gore, p. 230.

${ }^{273}$ Lemann, Gore Without a Script, p. 54.
} 
ticket with Clinton, ${ }^{274}$ but the decision to run with Clinton was in direct contrast to his stated position when writing Earth in the Balance. The book was liberating him from the restrictions of expectation and he was getting the opportunity to be authentic on a topic that was important to him. Yet it was the momentum toward a genuine and principled Gore that thrust him back into one of the most constrained roles in the U.S political system: the Vice Presidency. However, when asked, Gore did not hesitate when "[a]t around 11pm, July 8, 1992, Clinton made the call, and Gore instantly accepted. Tipper was vehemently opposed, hoping her husband would live up to his pledges to spend more time with the family." 275

Lemann ${ }^{276}$ contends that the book did not change Gore's character at all, rather that it was simply a tool to further the ambition he had longed for since childhood. Was the book simply a way of being noticed at a crucial time when Clinton was picking his running mate? This level of calculation could reveal a pattern seen previously with his sister's death and his subsequent assault on 'big tobacco', but on balance it seems a less calculating series of character traits were revealed. Both of these points in Gore's life reveal an individual who struggled to reconcile authenticity with expectation. The magnitude of his sister's death and his son's accident reveals authentic elements of his character that indicate deep reservoirs of feeling and strong views on issues and matters of principle. Up until these events he had been unable to express his own views for fear of straying from the centre and falling victim to the same fate as his father.

Nevertheless, with the decision to run with Clinton made, Gore threw himself into the role with total commitment. Gore did balance the ticket: he was a heavyweight on the environment, understood foreign affairs, knew his way around Washington, had little

\footnotetext{
${ }^{274}$ Morannis and Nakashima, The Prince of Tennessee, p. 266.

${ }^{275}$ Cockburn and St Clair, Al Gore: A User's Manual, p. 145.

${ }^{276}$ Lemann, Gore Without a Script, pp. 54-55.
} 
to hide (as he had run in 1988) and had served in Vietnam. Significantly, he was of the same generation as Clinton and also had a young photogenic family. ${ }^{277}$

On November 2, 1992, Clinton and Gore were elected President and Vice President of the United States. They "had polled 43 percent of the popular vote to 37 percent for Bush and 19 percent for Perot. In the electoral college, their vote total was 370 compared to 168 for Bush and zero for Perot."278

The test for Gore now was a choice between using the office to promote causes for which he had a genuine passion or being restricted by the office to ensure his longterm ambition to become president. The role was a serious and powerful one, with Clinton boasting he had the most influential Vice President in American history, but other analysis indicates it was a poor fit for Gore:

“... in hindsight the Vice-Presidency was a perilous role for Gore. It required him to suppress the full-throated passion to which he had pledged himself in "Earth in the Balance" and put him in close proximity to a man who, as a natural at the personal side of politics, might have been custom-designed to heighten his insecurities." 279

Gore helped Clinton enormously, but the role drove him to a moralistic and preachy disposition; his company was not easy, and he was likened to a policy graduate. ${ }^{280}$ The environment as an issue remained a reference point for his authentic self, manifested when he made the decision to attend the Kyoto conference in 1997 against the advice of his staff. ${ }^{281}$ A common thread had started to emerge on the one issue that could bring Gore out of himself.

Lemann interviewed Gore in 2000 and two images emerged. The first was Lemann's description, meeting Gore up close: "He has unusually white teeth and unusually blue

\footnotetext{
277 Morannis and Nakashima, The Prince of Tennessee, pp. 267-269.

278 Zelnick, Gore: A Political Life, p. 228.

${ }^{279}$ Lemann, Gore Without a Script, p. 56.

280 Ibid.

${ }^{281}$ Ibid, p. 57.
} 
eyes. I noticed that his fingernails were bitten to the quick." ${ }^{282}$ The second was a telling glimpse into the future:

"It also occurred to me that, whatever happens in this election, Gore's reaction will likely be just what it was after his previous Presidential race, in 1988. He'll want to redeem himself from his painful excursion into hard-nosed politics, with its blend of overcautious thought and overaggressive behaviour, by launching a moral crusade - either from inside the White House or from private life." 283

Two sets of traits exist side by side in Gore. The first is the in-control, wooden Gore: the striving perfectionist, cognisant of his father's downfall and trying to be all things to all people. The second is the impulsive moralist, determined to preach and teach things Gore believes in. The true test of authentic character was which of these traits would emerge from Gore if, in a presidential election, he were to lose.

282 Ibid, p. 58.

283 Ibid, p. 63. 


\section{CHAPTER SEVEN:}

\section{BUSH}

George Walker Bush was born in New Haven, Connecticut on 6 July 1946. He was the son of George Herbert Walker Bush, in due course the $41^{\text {st }}$ U.S. president, and Barbara Pierce, a distant relative of the $14^{\text {th }}$ US president Franklin Pierce. The Bush family had a long history in public life;

\footnotetext{
"Through five decades, there has always been a Bush as governor, senator, congressman, or president. Since the early 1950 's, there have been only rare, random interludes when a Bush hasn't been in a prominent political office."284
}

Bush's paternal grandfather, Prescott Bush, was a US senator and his brother Jeb Bush served as Governor of Florida. The schools the Bush family attended were mapped out for them, as were the sports they played and the clubs they joined. Even the state (Texas) they would dominate in the post-Johnson era was selected for the very reason that it would help them retain power, extending over three generations.

There appeared to be nothing random about George W. Bush's decision to enter politics and to run for president. Bush's paternal great-grandfather was Samuel Prescott Bush (who family members credited with introducing the Ohio State football program), ${ }^{285}$ whose son, named Prescott, was the first Bush to attend Yale - playing varsity baseball and football and joining the influential secret club, the Skull and Bones Society. In 1921, he married Dorothy Walker, the daughter of George Herbert Walker, co-founder of Brown Brothers Harriman (a private bank). The Walkers have their own Golf Cup and estates in Long Island and South Carolina. They define the Northeastern elite. ${ }^{286}$ Prescott and Dorothy had a son in 1924 named George Herbert Walker Bush. They settled in Greenwich, Connecticut, raising five children.

\footnotetext{
${ }^{284}$ Minutaglio, Bill. (1999). First Son - George W. Bush and the Bush Family Dynasty. New York: Random House, p. 6.

285 Ibid, p. 19.

286 Phillips, Kevin. (2004). American Dynasty - How the Bush Clan became the World's most Powerful and Dangerous Family. New York: Penguin, pp. 15-50.
} 
Bush Sr. was schooled at Phillips Academy in Andover, Massachusetts, and at 18 he entered the Navy. His plane was shot down over the Pacific while he was on a mission to destroy a radio transmitter on Chichi Jima - an island in the Pacific. By the time he was discharged from active duty he had been decorated twice and was on his way to Yale. Bush Sr. achieved early in his life and at Yale and

\begin{abstract}
“... by the time of his graduation in 1948, he had been elected to the Phi Beta Kappa fraternity (an honour traditionally associated with academic achievement), captained the Yale baseball team, played on the school soccer and basketball teams, was a member of the Torch Honor Society and the secretive Skull and Bones Society, and succeeded in winning the Gordon Brown Prize for 'all around student leadership'."287
\end{abstract}

Bush Sr. was expected to succeed. His father, Senator Prescott Bush, was an imperious figure, variously described as dignified, commanding 288 and stern, he even “... stopped speaking to his own brother when he left his wife and children to take up with a Philadelphia society woman." 289 It was unsurprising when Bush Sr. sought to strike out on his own, heading to Texas and away from the oversight of Bush and Walker influence. He was at pains to state in a 1983 interview that "If I were a psychoanalyser, I might conclude that I was trying not to compete with my father, but to do something on my own." 290

The reality is less clear. The Bush and Walker families were incredibly close and the intergenerational influence of the Northeastern clan continued to allow significant advantage and gain for those in the family who sought to 'go west'. The move to Texas, ostensibly to gain independence, could also be perceived as expansion. The same year (1950) that Bush Sr. went into business for himself in Texas, Prescott Bush ran unsuccessfully for the US Senate; he tried again in 1952 and this time was successful: "Prescott Bush was widely regarded as an adequate caretaker, certainly not an arching ideologue, someone who diligently defended the prevailing Republican

\footnotetext{
${ }^{287}$ Hatfield, James. (2002). Fortunate Son - George W. Bush and the Making of an American President. London: Vision, pp. 7-8.

288 Ibid, p. 8.

289 Phillips, American Dynasty, p. 137.

${ }^{290}$ Hatfield, Fortunate Son, p. 8.
} 
dogma: attacking communism, gingerly promoting internationalism, supporting the interests of big business." 291

Contemporaneously and ambitiously, Bush Sr. sought to bring republicanism to Midland, Texas at a time when Texas was heavily influenced by two of the strongest willed politicians in US history: Lyndon Johnson and Sam Rayburn. ${ }^{292}$ At the same time, the family was continuing to expand, including the arrival of Bush's sister Pauline Robinson "Robin" Bush. Tragedy would strike when, in 1953, Robin Bush died. The death of his sister had a profound impact on the young Bush and would cement his place as head of the next generation. With the death of Robin "... he was suddenly seven years older than the next child in the family." 293

The way the family dealt with the tragic death of Robin provides a telling insight into the character of Bush and his family. In the spring of 1953, Robin would be diagnosed with leukaemia, but although Bush knew his little sister was unwell, he had no idea she was dying. In fact his parents did not tell him of the seriousness of her illness until after she had died. It was Barbara who would care for Robin and during that time she barely left her bedside. The effects on Barbara were not just emotional as "[her] hair began to turn grey at the age of 28." 294 Why Bush was not told, according to Hatfield, was explained, simply, by his mother: "Well, it wouldn't have made a difference."295 Long after her death "George W.'s mother, who still [had] trouble discussing her daughter's death, question[ed] the decision not to tell her son that Robin was

\footnotetext{
${ }^{291}$ Minutaglio, First Son, p. 41.

292 Not only was Johnson a Congressman, a Senator, (and at age forty-four, the youngest Minority Leader ever, at age forty-six the Senate's youngest ever Majority Leader), a Vice-President and President of the United States, he was also a campaigner of extraordinary influence and liked to claim Texas as his own - most significantly: he was a Democrat. In many respects, however, Sam Rayburn was even more significant as a Democratic influence in Texas. Known in Washington as "Mr Sam" he served under eight presidents in a 49-year congressional career: 17 as Speaker of the U.S. House of Representatives; locally he was unbeatable.

${ }^{293}$ Minutaglio, First Son, p. 45.

${ }^{294}$ Hatfield, Fortunate Son, p. 14.

${ }^{295}$ Ibid, p. 15.
} 
terminally ill. 'I don't know if that was right or wrong' she has confessed. 'I mean, I really don't.",296

The significance of the loss of a sibling for Bush - and, for that matter, for Gore, Kennedy and Nixon - is a complex matter, but may have contributed to motivate each of them to strive for greatness in an almost compulsive way, as though they were trying to fulfil the expectations of their parents for two (or more) children.

In 1958, Bush Sr. moved the family to Houston where Bush's education got underway: although he would be expected to attend Andover, and then Yale, like his father, he was determined to carve out his own place without being referenced to his Northeastern roots. However, his father was not the most significant influence. Barbara Bush was the dominant force in the Bush household for two reasons. First, she was home - Bush Sr. was not. Second, her own pedigree was impressive. The Bush clan answered to their mother as she was the dominant and forceful personality in the family: "Jeb remembered. 'Mom was always the one to hand out the goodies and the discipline. In a sense it was a matriarchal family",. ${ }^{297}$

Once Bush arrived at Andover, his essential character seemed to consolidate itself. $\mathrm{He}$ ran in the right crowd and understood the significance of being in the right place at the right time. At social functions “... he was even more impossible to extract, inserting himself and always moving, mixing, approaching people, just as his father did but with a bit more bluster, like his mother." 298 This style was one that would stick with Bush it began to define him - along with the death of his sister:

\footnotetext{
"Years later, when he was running for re-election as governor of Texas, George W.'s parents acknowledged that their eldest son's 'back-slapping, wisecracking, occasionally teasing style' was developed as a child of seven, when his sister died, and he felt it was his responsibility to try and lift his parents out of their grief." 299
}

\footnotetext{
296 Ibid.

${ }^{297}$ Minutaglio, First Son, p. 57.

${ }^{298}$ Ibid, p. 58.

299 Hatfield, Fortunate Son, p. 15.
} 


\begin{abstract}
"By his last year at the academy, Junior had gained a measure of independence from his wellconnected family and made new friends who saw the former class clown from Texas as an extroverted, likeable kid with a gift ... for being a 'regular guy'."300
\end{abstract}

Bush's character style would not change, or adjust, under the pressures of Yale although it was a place where his father had excelled - as he had decided not to compete with him. The events of 1964 would confirm why such a strategy was worth investing in. First, his grandfather Prescott Bush would retire from the U.S. Senate. Secondly, his father would run unsuccessfully against incumbent Democrat Senator Ralph Yarborough. Despite Bush Sr. trying to present himself as being independent from his Northeastern ties and despite climbing the Texas Republican ladder, Yarborough labelled him a carpet-bagger - an outsider - and it stuck. He beat Bush Sr. by 300,000 votes. In an analysis of this race, Minutaglio offers the view that the voters rejected Bush (Sr.) because of who he was, and what the Bush-Walker family symbolised, rather than what he proposed. ${ }^{301}$ This lesson would resonate with Bush, who seemed from that point on to become even more 'Texan' in manner and disposition. At a crossroads, he would continue to wrestle with the development of his own character traits: to decide whether to fall back on his name; his connections and his wealth, or to deliberately carve out his own style.

At Yale, the extroverted social glad-hander began to emerge as the primary character, but the genetic predisposition to his family connections remained intuitive and "... his inherited skills - subtle, like any personal touch, but distinct - were always evident, especially his photographic memory." 302 It was his memory, now linked to his habit of giving those around him nicknames, that seemed so comprehensive and without effort to those who observed him during this time. His classmate Clay Johnson

"... recalled the time when he and Junior were fraternity pledges during their sophomore year at [Yale] and the upperclassmen ordered them to stand and attempt to name the other 50 initiates. 'The average person stood up and named about three ... George got up and named all 50." $" 303$

\footnotetext{
${ }^{300}$ Ibid, p. 20.

${ }^{301}$ Minutaglio, First Son, p. 83.

${ }^{302}$ Hatfield, Fortunate Son, p. 21.

303 Ibid.
} 
While he did join his father's old fraternity, his essential choice was to deliberately distance himself from his Northeastern roots. He saw himself as Texan and he was going to stamp that impression firmly on his classmates' minds:

"[t]o understand this transformation, consider the tale of George W. Bush not following in his father's footsteps. From a fairly early age, he was more of a rascal and less of an Ivy League gentleman in training, a Texas cutup with a Texas drawl." 304

However, Bush was still elected president of the Delta Kappa Epsilon fraternity, the same fraternity his father had belonged to. He also became a member of the Skull and Bones Society where "Prescott Bush, George Herbert Walker, Jonathon Bush [Bush's uncle], George Herbert Walker Bush, and his cousin Ray Walker had been Bonesmen". ${ }^{305}$

In 1968 Bush confronted the dilemma of Vietnam with an answer that suited his own style: he enlisted with the Texas Air National Guard. He worked hard to ensure his service was not compared to his father's own war record:

"Junior's stint in the Guard was one continuous party where he could 'fly-hard, play-hard, drink-hard' and when he wasn't flying jets, he spent, as he later confessed, 'enormous amounts of time and energy courting women', receiving the well-earned reputation of 'being the wild Bush son'." 306

Despite a 'party hard' attitude at Yale, Bush still managed to achieve to a relatively high standard by graduating with a history degree and as a fraternity president while also earning his National Guard wings in December 1969. Bush was meeting the necessary family standard without distorting his essential character - his likeability.

In January 1970, Bush Sr declared he was running for the US Senate, losing to Lloyd Bentsen, who gained $53.4 \%$ of the vote. Suggestions remained that "... the elder Bush ... [was] a latter-day northeasterner despatched to Texas by the family ..."307. It was then that President Nixon made Bush Sr. the U.S. Ambassador to the United Nations.

\footnotetext{
${ }^{304}$ Phillips, Kevin. (2004). American Dynasty. New York: Anchor Books, p. 48.

${ }^{305}$ Minutaglio, First Son, p. 103.

${ }^{306}$ Hatfield, Fortunate Son, p. 29.

${ }^{307}$ Minutaglio, First Son, p. 133.
} 
At Christmas 1972, at his parents' home, Bush confronted his father in a heated row and then to the surprise of his parents announced he was going to study at Harvard. He left his National Guard post early in October 1973 and set off for more time in the Ivy League. He was a now fully transformed Texan and would wear his flight jacket to class, cowboy boots on campus, while carrying a spit cup with him for his chewing tobacco. ${ }^{308}$ Following graduation from Harvard in 1975 Bush headed back to Midland, Texas, beginning two of the most important relationships in his life: his marriage to Laura Welch on 5 November 1977, three months after he met her, and a life-long friendship with a political operative named Karl C. Rove. Both would refine the character of Bush over the next twenty years: they would settle him and prepare him for the challenges that lay ahead, but they would not change the essence of Bush - his self-belief.

In 1977 Congressman George Mahon announced he was retiring from politics after 22 terms and Bush decided he would run for the Nineteenth Congressional District. $\mathrm{He}$ would soon learn that walking, talking and acting Texan would not be enough. There were twelve contenders for the GOP nomination, and it came down in the end to just two of them - Bush and Odessa mayor Jim Reese. ${ }^{309}$ Bush won the GOP primary, pitting him in the election against Democrat Kent Hance. Although Bush performed respectably, gaining $47 \%$ of the vote, the usual accusations of carpet-bagging and ties to the Northeast ultimately cost him the election. According to Minutaglio, "a third of [the money for the Bush campaign] was flooding in from outside West Texas." 310 The tension of gaining his Texan independence was further compromised when "[f]our months after Bush [lost to Hance] ... [Bush Sr.] announced to the National Press Club that he was running for President." 311

\footnotetext{
${ }^{308}$ Hatfield, Fortunate Son, p. 34.

309 Phillips, American Dynasty, p. 46.

${ }^{310}$ Minutaglio, First Son, pp. 189-190.

${ }^{311}$ Ibid, p. 195.
} 
Distancing himself from his father was now virtually impossible. At the Republican National Convention Bush Snr. was confirmed as running mate to Ronald Reagan, and for the next eight years Bush was the son of the Vice-President of the United States.

Two further changes in Bush's developing character would occur by the time his father transitioned from Vice-President to become President. The first was his decision to become 'born-again' with his version of faith.

"By 1985-86, evangelist Billy Graham had, in Bush's own words, 'planted a mustard seed' of salvation in his soul. ... George W. was studying the Bible, giving up liquor (in 1986), and preparing to put his new 'born-again' faith to the test by assuming responsibility for liaison with the Religious Right in the 1988 presidential campaign, which his father was assembling. $" 312$

The second development was his involvement in his father's 1988 presidential campaign. Bush was to witness first hand what was required to win and his influence and connections during this period were vital to the success of his father's campaign, so much so that "November brought George H. W. Bush 70 percent of the evangelical vote, just 5 points below Reagan's 1984 landslide share." 313 Bush Sr. won the election with 48,886,097 votes to Dukakis's 41,809,074; in Electoral College votes the victory was even more telling, with Bush winning 426 to his opponent's 111. Bush was now the son of the President of the United States.

The biggest challenge for the family came during the reelection campaign of 1992, with the emergence of a young candidate from Arkansas named Bill Clinton. Bush Sr. seemed invincible heading into the campaign but the result was resounding. Clinton secured 44,909,326 votes to Bush's 39,103,882, with an Electoral College margin of 370 votes to Bush's 168. It was said of that campaign that the "Bushes and Walkers were still too preppy, too wimpy, too rich, too out of touch with real working Americans." $" 314$

\footnotetext{
312 Phillips, American Dynasty, pp. 212-213.

313 Ibid, p. 214.

${ }^{314}$ Minutaglio, First Son, p. 263.
} 
Just as Gore had learned his trade by witnessing the defeat of his father, Bush too would have his resolve to win hardened by his father's loss. Bush was determined not to repeat the same mistakes his father had made and "[a] month after the election, he returned to his $11^{\text {th }}$-floor Texas Rangers office and made a 'lesson-plan', as his ... wife ... called it." 315

The most important of those points, outlined by Hatfield, was the emergence of a new Bush style which the American public would see more of over the next 14 years: to "[c]ome out swinging - whether incumbent or challenger."316 These valuable lessons would mesh with the self-certainty Bush had as his DNA, the zeal he had gained from his religious conversion, his life-long torment in trying to distance himself from the elitism of his family's Northeastern roots and his single-minded determination to be a contributor taking on challenges beyond the capacity of just one sibling when he decided to run for the job of Governor of Texas in 1994.

The campaign against the popular sitting Democratic Governor, Ann Richards, was a battle of significance. It appeared an uphill battle: “... Labor Day 1994, Ann Richards had approval ratings of well over 60 percent: crime was down, school scores were up, the economy was humming, there were no new taxes, and throughout this favored land the sun was shining bright. Nine weeks later she was out of office."317

It emerged that there was sufficient anti-Clinton sentiment among the populace as early as 1994 for the Republicans to sense that electoral gains could be made, particularly in the Southern states. Richards saw the attacks coming and was quoted as saying Bush Sr. had been born with a silver foot in his mouth, but she was not prepared for Bush attracting and mobilising the 'three g's' - God, gays and guns. ${ }^{318}$

\footnotetext{
${ }^{315}$ Hatfield, Fortunate Son, p. 73. In 1989, Bush became co-owner of the Texas Rangers baseball team, a financial investment which also added to his 'Texas' credentials.

316 Ibid, p. 74.

${ }^{317}$ Ivins, Molly and Dubose, Lou. (2000). Shrub - The Short but Happy Political Life of George W. Bush. New York: Random House, pp. 43-44.

${ }^{318}$ Ibid, p. 44.
} 
Bush would win comfortably, taking $53.5 \%$ of the vote to Richard's $45.9 \%$; he became only the second Republican to be elected Texas governor since Reconstruction. ${ }^{319}$ His bold run in 1998 for a second term as Governor saw him pitted against the unfortunate Texas Land Commissioner, Garry Mauro. It was a massacre; Mauro “... was subjected to unprecedented political humiliation as over 100 statewide officeholders in his own party publicly deserted him and endorsed his Republican opponent ..." 320

Bush became the first Texas Governor to win elusive back-to-back four year terms, but there were still essential questions to be answered about his own character. First, was Bush the genuine Texas article or just a Northeastern interloper who had made a home in Texas? Secondly, what price would the independence he sought from his family extract? Thirdly, could he achieve an aura of self-assuredness, without it appearing as though he thought himself simply "entitled" to the job he and his family sought?

The overwhelming self-confidence Bush possessed meant he did not limit himself to one set of character traits over another. He effortlessly moved between them, exhibiting a range of traits in different situations; always doing so to gain the biggest political impact.

A larger question of authenticity remained: with his quest to win the White House looming, which set of traits would emerge in the event that it was unclear who had won the 2000 Presidential election, and would the authentic Bush be revealed?

\footnotetext{
${ }^{319}$ Hatfield, Fortunate Son, p. 92.

${ }^{320}$ Ibid, p. 157.
} 


\section{CHAPTER EIGHT:}

\section{THE 2000 ELECTION}

This chapter examines several different components of the 2000 election. First, it examines the nomination process for each candidate. Secondly, the selection of each candidate's running mate is analysed with an emphasis on how (or whether) this choice reflected the authenticity of each candidate's character. Next, the influence of television in the election is considered. Fourthly, the role of the incumbent president, Bill Clinton, is examined.

A fifth area for examination involves the role of the courts in deciding the outcome. It is not the intention of this thesis to analyse the arguments or judgments of those courts; rather, the chapter considers how each candidate reacted to those decisions and what those reactions revealed about the candidate's character. The sixth and final part of this chapter applies the theoretical models set out in chapter 2 to the decisions taken by each candidate during the heat of the election result, leading to an analysis of Gore's reaction to the final outcome, with a conclusion as to whether that reaction was authentic.

November 7, 2000 was the date of the presidential election. By the following day, in three states (Florida, Oregon and New Mexico) the result was too close to call. The main television networks had called Florida for Gore earlier the previous evening, having then to embarrassingly change their minds and announce it was too tight to offer a definitive view. Initially, when the first call was made, newsreader Dan Rather had told viewers, "If we call a state, you can take it to the bank. Book it!"321

321 Ceaser, James W. and Busch, Andrew E. (2001). The Perfect Tie: The True Story of the 2000 Presidential Election. Lanham: Rowman \& Littlefield, p. 9. 
He was wrong. For a whole month no final result was known, until $10 \mathrm{pm}$ on 12 December, when the U.S. Supreme Court ruled, 5-4, in favour of George W. Bush. ${ }^{322}$ The following day Gore formally conceded to Bush - for the second time. ${ }^{323}$ This time he did not retract his concession.

Gore and his running mate, Senator Joseph Lieberman, secured 50,999,897 votes, Bush and his running mate, Dick Cheney, secured 50,456,002, a difference of 543,895 votes between the Democrat and Republican candidates in the nationwide popular vote. The country, it seemed, wanted to elect Gore as its president, but the Electoral College vote confirmed that Bush had gained 271 votes to the 266 votes won by Gore. The reality was that the election was far closer than the margin of 543,895 votes. Florida alone became significant in determining who could claim victory, with Bush certified the winner by 537 votes on 26 November, awarding 25 Electoral College votes to the Republican nominee. The declaration did not include the Palm Beach County recount in the tally.

As with the 1960 result, it is appropriate to begin analysis of the election with the successful candidate. Although Bush was determined to present himself as a new type of Republican candidate, the race was far from straightforward, with a determined challenge from Senator John McCain. The early stages of the primary race also saw “... former Secretary of Labor Elizabeth Dole, publisher Steve Forbes, Family Research Council President Gary Bauer, ... Utah Senator Orrin Hatch, and former Ambassador Alan Keyes" enter the race. ${ }^{324}$

\footnotetext{
${ }^{322}$ See: Judgment of the Supreme Court of the United States: Bush v. Gore, 531 U.S. 98 (2000).

${ }^{323}$ Sunstein, Cass R. and Epstein, Richard A. (eds.). (2001). The Vote: Bush, Gore and the Supreme Court. Chicago: University of Chicago Press, p. 2. "At 2:15am on November 8, the networks started to call Bush the winner in Florida ... [f] ifteen minutes later Gore telephoned Bush to concede. At 3:45am Gore called Bush again, retracting his concession."

324 Weiss, Melanie S. (2003). The Election of 2000. In William G. Shade \& Ballard C. Campbell (eds.), American Presidential Campaigns and Elections. New York: M.E. Sharpe, p. 1035.
} 
Realistically, only McCain was a serious threat to Bush: he had a history of heroism in the Vietnam War and his political experience was significant. Campaign finance reform and his reputation for no-nonsense 'straight-talking' was in direct contrast to any dynastic entitlement of the Bush family. McCain was considered a very strong contender when he scored an upset victory over Bush in New Hampshire, winning by more than $19 \%$ of the vote. McCain had real appeal to moderates and independents:

\footnotetext{
"After New Hampshire, an open primary state, McCain almost overcame Bush in South Carolina, and then he defeated him by a significant margin in Michigan, both open primary states. McCain was competitive in these races only because of the votes of independents and Democrats." 325
}

In uniting the party base and by bringing in the Christian Right, Bush had made himself largely unavailable to the 'cross-over' voter. Independents and moderates were unlikely to be persuaded by the more extremist positions Bush came to represent. But in the interim this tactic was working for Bush: he was gathering up the party loyalist vote, ensuring McCain only managed to win seven states and, in the end, only 231 delegates. ${ }^{326}$ By March 2000 McCain had pulled out of the race, having signalled that as a nominee from the right, Bush had exposed the centre as an opportunity for the Democrats.

The selection of his running mate needed to maintain the momentum of Bush's campaign and he focussed on who would be best for him in office, not during the campaign.

"If his choice was to be based on geography, Bush would have chosen from among other vice presidential finalists from key states or constituencies, such as Governor Tom Ridge of Pennsylvania or Frank Keating of Oklahoma. Ridge, popular in his state, might have helped Bush in Pennsylvania, as Keating, a Catholic, might have among Catholic voters in the industrial Midwest ... Cheney came from Wyoming, a state holding [only] three electoral votes in confirmed 'Bush country." ${ }^{\prime 327}$

\footnotetext{
${ }^{325}$ Ceaser and Busch, The Perfect Tie, pp. 53-54.

${ }^{326}$ Weiss, The Election of 2000, pp. 1036.

${ }^{327}$ Ceaser and Busch, The Perfect Tie, p. 138.
} 
Cheney added nothing to expand Bush's voting base ${ }^{328}$ but would be useful against claims that Bush lacked experience. A former congressman from Wyoming, Cheney had been Secretary of Defence for the first Bush President. He had served as Chief of Staff under President Ford and he knew Washington. It proved to be an effective choice when during the campaign

" ... in the vice presidential debate in early October, at the time of a flare-up in the Mideast between Israel and the Palestinians. Both candidates did very well in that debate - so much so that many newspapers editorialised that both tickets would have done better to reverse the positions of the candidates - but Cheney's performance was superb ... helping to keep public opinion in Bush's favour." 329

In choosing Cheney, Bush also reflected the influence of his father. As this thesis has contended, Bush was determined to etch out his own character free from the strings of his family, yet in a demonstration of dependency, he ultimately chose a running mate who had served his father and would provide a clear link to his father's presidency. Although Bush was independent in manner, style and political ideology, when it came to crucial decisions he chose people that had previously served his family.

The race for the Democratic nomination should have been just as clear-cut, but Gore did not help himself. Each decision made during the primaries saw Gore stuck between associating himself with the stability and economic success of the Clinton years and being too close to a President who had sullied the Democratic ticket and been subject to impeachment proceedings relating to the Lewinsky scandal. When Clinton was acquitted on 12 February 1999 by the U.S. Senate, it left Gore in a most unsatisfactory place. Gore made a choice right from the start: “Declaring ... 'I am my own man,' [he chose] to distance himself from Clinton altogether. The path he chose was a call for a 'new morality' and an appeal to political moderates." 330

The challenger for Gore was the former U.S. Senator for New Jersey and former New York Knicks basketball star, Bill Bradley. Bradley was engaging and personable, a

\footnotetext{
328 As an alternative, Bush could have selected McCain as his running mate, as Reagan had done with Bush Sr. so as to smooth the way to victory.

${ }^{329}$ Ceaser and Busch, The Perfect Tie, p. 140.

${ }^{330}$ Weiss, The Election of 2000, p. 1034.
} 
Princeton graduate, experienced and with star appeal. He knew what he stood for and was passionate about it. Bradley was determined his campaign would emphasise “... an end to capital punishment, continued support for affirmative action policies, gun control, and a more significant push for national healthcare. Still, groups such as African Americans and labor, who had long supported Clinton, tended to favour Gore over Bradley." ${ }^{331}$ Eventually, Gore was able to emphasise a lack of candour over Bradley's missing support for disaster relief after floods in 1993. Further, Bradley was

“... slowed down by a recurring heart condition that took him off the campaign trail ... [in Iowa] ... for several days ... [and] he failed for some time to acknowledge ... his condition and withheld his relevant medical records.” 332

Significantly, even as a sitting Vice-President, Gore was initially run close by Bradley. On 1 February 2000, the day of the New Hampshire primary, "Bradley trailed Gore by only 5 percent, receiving 47 percent of the vote compared to Gore's 52 percent." 333 However, Gore gained the desire to win again and "Bradley's defeat can be attributed to his unwillingness to respond to Gore's aggressive tactics until very late in the contest ... it was Gore who seemed to have the athlete's proverbial 'fire in the belly'." 334 Significantly, it was also McCain's capture of the independent vote that cost Bradley, and "[a]bove all ... Gore beat Bradley because McCain beat Bradley first. Had that not occurred, Bradley might easily have won New Hampshire and left Al Gore struggling for five weeks." 335 By the time 'Super Tuesday' occurred on March 7, Bradley was finished and "one day later, Bradley withdrew from the race."336

Gore selected a running mate well before the Democratic convention and the choice was textbook Gore. Unlike Bush, who considered who would best complement his skills once in office, Gore was determined to present a balanced and electorally advantageous ticket. However, "[p]icking a geographically advantageous vice

\footnotetext{
${ }^{331}$ Ibid.

${ }^{332}$ Ceaser and Busch, The Perfect Tie, p. 79.

${ }^{333}$ Weiss, The Election of 2000, p. 1034.

${ }^{334}$ Ceaser and Busch, The Perfect Tie, p. 83.

${ }^{335}$ Ibid, p. 98.

${ }^{336}$ Weiss, The Election of 2000, p. 1034.
} 
president for Gore might have meant choosing Senator Evan Bayh of Indiana, John Edwards of North Carolina or Bob Graham of Florida." 337 However, Gore selected Joseph I. Lieberman of Connecticut, a centrist Democrat who had been in the Senate since 1988. Gore may have liked and respected Lieberman, even regarded him as a good Vice President, but the compelling factor in the selection was the shadow of Bill Clinton: Lieberman was the first Democratic Senator to publicly, and strongly, criticise Clinton's conduct in the Lewinsky scandal, and in his determination to distance himself from Clinton, Gore made a decision to pick the candidate the voting public would most readily identify as having been critical of Clinton.

It has been observed that the addition of Lieberman to the ticket added further advantages. ${ }^{338}$ Whether the Jewish heritage of Lieberman was of direct benefit remains debatable, but there was some logic to the view that he added weight to Democratic hopes in Florida. The problem was that although the addition of Lieberman may have shored up core Democratic votes, it appeared to do very little to grow the vote in vital demographics. "The Gore-Lieberman ticket, in some measure because of Joe Lieberman, played best in urban and suburban areas, while it lost ground in smalltown and rural America." 339

The most compelling factor in the choice of the two running mates for the 2000 election was not who was chosen - but why they were chosen. The difference of approach by Gore and Bush was subtle but significant. Bush, always self-assured, chose someone who could compensate for his shortcomings in office, while Gore, desperate to win at any cost, chose his running mate in a very defensive manner by selecting the person most likely to be seen as putting distance between himself and Bill Clinton. Although Clinton was widely regarded as one of the best campaigners of his generation, Gore refused to allow him to campaign for fear of being tarred by him and the Lewinsky affair.

\footnotetext{
${ }^{337}$ Ceaser and Busch, The Perfect Tie, p. 138.

${ }^{338}$ Ibid, p. 139.

${ }^{339}$ Ibid. p. 140.
} 
The decision to keep Clinton 'at home' may well have cost Gore the presidency. He simply could not reconcile the fact that he could be his own person, and claim some of the successes of the Clinton years at the same time. In a relevant article, ${ }^{340}$ the authors argue that Gore did not receive, electorally, a historically normal amount of credit for the performance of the Clinton administration. Secondary contributing factors included the effects of Clinton's personal affairs and Gore's decision to run to the left of where Clinton had positioned the Democratic Party. After decades of trying to being seen as his own person, Gore formed the view that this election was the one to assert that independence: not because he had come of political age or a crisis had triggered the emergence of the 'real' Gore, but because it is what Gore thought the public wanted, or expected, of him. Put another way, the character traits on display revealed an attempt to please; they were not an outward expression of his inner true self: it was not authentic in nature. Gore's campaign approach also prevented him from emphasising his time as Vice President. In fact, Gore made the situation worse by using phrases such as 'This is an election about the future not the past', ${ }^{341}$ effectively encouraging the public to disassociate him from the last eight years - including all the positive aspects of that period. Further, Gore was determined to be liberal; again, not because he necessarily believed in those views, ${ }^{342}$ but because it would minimise his close association with Clinton - a middle ground moderate.

Fiorina et al contend that had Gore received the same boost from Clinton's performance in 2000 that Bush Sr. did from Reagan's performance in 1988, he would have received about eight more percentage points of the vote. ${ }^{343}$ They also assert that had Gore tied himself more closely to the economic successes of the Clinton administration, the link to Clinton's morality would have been a damaging factor. Comparative statistical modelling confirms this view. ${ }^{344}$ But the unanswered question

\footnotetext{
${ }^{340}$ Fiorina, Morris, Abrams, Samuel and Pope, Jeremy. (2003). The 2000 US Presidential Election: Can Retrospective Voting be Saved? British Journal of Political Science, 33(2), pp. 163-187.

${ }^{341}$ Ibid, p. 167.

342 As noted, Bradley had clearly occupied that territory during the primary race.

${ }^{343}$ Fiorina et al, The 2000 US Presidential Election, p. 175.

${ }^{344}$ Ibid, pp. 184-185.
} 
remains as to whether this downside would have been significant enough to offset any gains Gore may have won from his proximity to Clinton's overall record and legacy.

“... Gore was already suffering from the fallout of Clinton's behaviour and would have lost no more had he tried to emphasize the positive accomplishments of the administration. Had Gore captured just one more small state - Arkansas, Missouri, Nevada, New Hampshire, West Virginia - that he narrowly lost, Florida would have been irrelevant."345

Gore had chosen to treat Clinton as he had treated his father: he sought to define himself by distancing himself from someone close to him. It is worth posing the question: would the Democrats have lost states like Tennessee and Arkansas if Clinton had been actively supporting Gore?

Core messages between Bush and Gore became indistinguishable during the campaign as each candidate tried to attract moderate and independent voters who had not committed to a candidate during the primary season. Weiss spells out the convergence of themes: "As Gore and Lieberman moved toward the right during the course of the campaign, Bush and Cheney moved leftward, heading toward the political center. It became increasingly difficult to distinguish between the candidates' views." 346 Waldman and Hall Jamieson also contend that both Bush and Gore described their policy positions in ways that made distinctions difficult to draw:

"Public ignorance of the candidates' actual positions was particularly damaging to Gore, since many voters were unaware that they agreed with the Democrat on a variety of issues. Since Gore's positions were more popular, the election can be understood in part as a successful effort by Bush to limit understanding of issue distinctions and an unsuccessful effort by Gore to clarify those distinctions." 347

This theory of 'rhetorical convergence' meant that candidates' likeability took centre stage. Waldman and Hall Jamieson describe the quandry: "Many post election journalistic analyses concluded that while Gore had an advantage on the issues, voters found Bush to be the more appealing personality." ${ }^{348}$ Bishin et al support this analysis

\footnotetext{
${ }^{345}$ Ibid, p. 185.

346 Weiss, The Election of 2000, p. 1038.

347 Waldman, Paul and Hall Jamieson, Kathleen. Rhetorical Convergence and Issue Knowledge in the 2000 Presidential Election. Presidential Studies Quarterly, 33(1), 2003, p. 1.

348 Ibid, p. 8.
} 
by noting “... [c]learly, character evaluations played a highly significant role in the 2000 election." $" 349$

As in 1960, the role of the candidates' television debates was again a focus. Gore started with an advantage as he had been a US Senator and Vice President. The debates were his to lose; he did just that.

The first debate, on 3 October, gave Bush the change in momentum he needed. It was here that the questions about Gore's propensity to exaggerate were first highlighted. Gore had been "... caught in three fibs in one week ..."350 and Bush was quick to capitalise by making 'trust' a central platform of the campaign. It also went directly to the issue of character; it tied in a lack of trust in the previous administration and started to feed the view that Gore would do whatever it took to get to the White House, a theme to which the Bush campaign would return. Gore's behaviour during the debates (including sighing and eye-rolling) was viewed as arrogance, and soon questions about his likeability and character were back as the focal point of the campaign. Gore's authenticity was further questioned in the second debate when a less aggressive Gore was on display:

“...Gore's advisors had seemed to remove his alpha male gene. The lion had become a lamb. After the debate was over, commentators again posed the damaging question about who was the 'real' Al Gore. In the first two debates the American people had seen two almost completely different versions." 351 (emphasis added)

Gore had a better third debate, but by then a substantial number of questions regarding his character were already in play. He had by that stage exhibited three competing versions of himself.

\footnotetext{
349 Bishin, Benjamin G., Stevens, Daniel and Wilson, Christian. (2006). Character Counts: Honesty and Fairness in Election 2000. Public Opinion Quarterly, 70(2), p. 240.

350 Ceaser and Busch, The Perfect Tie, p. 149. These included: “a story that his mother's arthritis medicine cost more than the same medicine for his dog (he had actually taken an example from a House Democratic policy study); a claim that he had participated in discussions on the oil reserve since its inception (it was begun before he entered Congress); and a reminiscence that a famous union song had served as his lullaby as a baby (he was 27 years old when it was written)".

${ }^{351}$ Ceaser and Busch, The Perfect Tie, p. 151.
} 
As noted, the 2000 election did not end on polling day (November 7), with the final result so convoluted that it took the U.S. Supreme Court until 12 December to ultimately declare Bush the winner of the election. ${ }^{352}$ The purpose of this thesis is not to relitigate various court decisions, but rather to highlight character tendencies evident during the process.

It was Gore who initiated the recounts of ballots cast in Broward, Miami-Dade, Palm Beach and Volusia counties in Florida, but it was Bush whose campaign filed the first set of legal proceedings (on 11 November). The subsequent suing and counter-suing was a test of nerves between Bush and Gore as to which team could hold the momentum toward the inauguration date. It was high stakes and by taking the 'firstmover-advantage' a candidate could easily look panicked. Although Bush made the first legal move, his reaction to the process was one of steady composure.

The 'likeability' of Bush continued as his primary character trait on display during this crucial period. Before the U.S. Supreme Court handed down its final ruling on 12 December, Bush was certified the victor in Florida by the Florida Elections Canvassing Commission by a mere 537 votes. This was crucial: the Gore camp had been advocating an "in your heart you know he's won" 353 narrative, but was actually implementing a strategy at odds with the team's purely legalistic approach to determining the election outcome. Gore's strategy was confused and given the closeness of the election this continued to add to the lack of certainty and "presidential behaviour" voters were looking for in the electoral aftermath.

In applying the theoretical framework set out in chapter 2 to the candidates, it is convenient to begin with George W. Bush.

\footnotetext{
${ }^{352}$ For the Court's ruling and all nine Justices' opinions see: Dionne, E.J. Jr. and Kristol, William (eds.). (2001). Bush v. Gore: The Court Cases and the Commentary. Washington, D.C: Brookings Institute Press.

${ }^{353}$ Ceaser and Busch, The Perfect Tie, p. 180.
} 
Using the model provided by Barber, how had Bush "orientated himself toward life, not for the moment, but enduringly"? ${ }^{354}$ Bush was likeable and not someone who lacked ambition; he had the bearing of an individual with great self confidence and he achieved in life without appearing to be rattled. He was determined not to be 'the boy from the east' but rather the genuine article from Texas, and he worked hard to convey that impression. Importantly, Bush also knew his limitations, so much so that he chose a running mate on that basis. There was nothing hesitant about his 2000 election campaign, always operating on the basis that he would make it. Even during the court battles that preceded the final determination he was calm and measured in his approach. In effect, he was trying to remind the American people not of his father's style, but of Reagan's: calm, confident, good-humoured.

Bush's character, style and world view was inward looking and self assured; he did not try to alter that persona once he decided as a young man what it should be. In applying Barber's model, Bush made sense. His style was effectively unchanged from college. That style did include rhetoric (notions of compassionate conservatism), close informal dealing (use of nicknames) and a cognitive component (his consistent and deliberately reassuring nature).

Gardner's model, which includes the distinction between leaders and managers, resonates with Bush. Bush never held himself out to be a policy expert and during the debates with Gore he was considered to have done well when he simply held his own. Staying on message was his specialty; he was happy sticking to big messages and insisted on preserving time for himself (his daily exercise time was a Bush staple). That regular exercise programme was real (as opposed to manufactured) and Bush easily meets the tests of vitality and stamina (physical at least) assessed as part of the Gardner requirements. Bush also met the intelligence criteria. Even if his results at Yale and Harvard were less than stellar, Bush had what so many leaders lack when assessing the authentic nature of their character: insight into self. Bush understood his own limitations and did not pretend to be something he was not.

\footnotetext{
${ }^{354}$ Barber, The Presidential Character, p. 8.
} 
How Bush fits within Burns' model also confirms authenticity of character. Motive and resource were present, with the wealth, connections and experience of his family invaluable. The resource was spread from the Eastern elite right through to the Texan oil fields, the domain of several generations. The issue of motive warrants closer attention. The need to right the loss his father had suffered at the hands of Clinton and Gore would have been a factor in his decision to run, but additionally, motive for Bush as the next generational leader of the family was also a strong factor in assuming the responsibility to lead, as canvassed in chapter 7 .

Under the Burns model Bush meets the two elements outlined. He had the intuitive confidence to relax into who he was and the motive to determine who he would be from a very young age. Like Kennedy before him, Bush meets the framework proposed by Barber as an 'active-positive'. Although the model requires activity and enjoyment as fundamental, Bush is a closer fit than that narrow context may imply. This thesis concludes that Bush saw himself as developing over time towards welldefined personal goals, and although he may have lost his way briefly in his youth before meeting Laura and 'finding his faith', he knew how he must be seen and had a keen sense of "growing toward his image of himself as he might yet be",355 and rational mastery was clearly evident in the choices he made. The consistency in the way he applied those early choices to his behaviour during the 2000 campaign, and ultimately to his presidency, bears this out.

As noted, Neustadt places emphasis on a capacity to persuade as an important factor in determining whether leadership is apparent in a candidate's character. With Bush, he appeared during the 2000 campaign to be moderate in outlook (compassionate conservatism) while maintaining his convictions in a non-threatening way. His demeanour, more than any other attribute, gave rise to the view he could be trusted, meaning he was in a far better position to persuade. By the end of the campaign he presented an operating style that lent itself to a conservative sense of idealism centred

\footnotetext{
${ }^{355}$ Ibid, p. 12.
} 
on what was morally right (God); what freedoms Americans should enjoy (guns); and the role of government in the lives of ordinary Americans (small government). During his candidacy and presidency post-9/11, it was clear Bush saw himself as a decisionmaker at the centre of power. Americans had seen that model before, with Reagan, and were prepared for it again in 2000 .

The three components offered by the Hargrove model overlay neatly on Bush. Bush did eventually balance purpose and prudence in his character by leaving behind his wayward youth for a more structured personality leading into the 2000 campaign. Like Kennedy picking Johnson, his selection of Cheney as his running mate exhibited an understanding of his own shortcomings. The second component offered by Hargrove, teaching reality, is also met. Bush believed standards and morality should be returned to the White House following the Clinton years and stood up for those views, trying to sell the message to the voters and to inform them, whilst simultaneously not seeking to divide the polity in the way Nixon had. The final factor of skill is less obvious in the candidacy of Bush. He was lacking in experience and grasp of policy detail, bringing into question whether he had the intellectual rigour to apply a healthy framework of flexibility to his psychological state and decision-making processes.

The last model to apply to Bush involves the three elements of Renshon's framework. Bush meets the first as his drive and determination translated into ambition; he was resolute, both before and during the court cases which were determining the 2000 outcome. He did not fold, seeming almost Presidential during the recount process. He quietly selected a Cabinet and an administration, not conceding only to retract (as Gore had done).

The second element, integrity, is also met: it is the cornerstone of where a candidate's ideals are realised. Bush, like Kennedy, has a source for his self-esteem, stemming from ideals of simplicity and the moral high ground. Bush became the person he saw himself to be at a younger age, having worked hard to embed those traits over his life. Authenticity in that regard was not fleeting, but enduring. 
The final element, of relatedness, is a more complex proposition. Bush had the ability to draw others to him, particularly as a young man when he was the life of the party, but in political adulthood he drew into his company primarily those who had served his father, not himself. In that sense, his abilities in this area fall short of the test set by Renshon.

The character-style model offered by Renshon is also not as easily applied to the Bush candidacy. His cognitive capacity was more aligned to ease of self and his interactions with others, rather than an intellectual application. Bush had an approach that was folksy rather than academic, and unlike Kennedy he worked hard not to appear elitist or curious in the intellectual sense. It is difficult when applying a range of theoretical models to overlook the one common factor that the Bush candidacy applies to them all - consistency. This steady, unruffled approach helped him win the presidency and on balance his character in the circumstances of the 2000 election can be judged as authentic.

Undertaking an examination of the authentic nature of Al Gore's character against the various theoretical models is more complex. His multi-faceted character manifests itself in the habit of trying to be all things to all people. He seemed, as a candidate, to lack a guiding light - a single purpose - and although he tried to relax, his essential character seemed at times unable to penetrate his need to please. Unlike Nixon, Gore did not have a life of hardship, but he certainly did not enjoy the luxurious upbringing of Bush or Kennedy. Nevertheless, his proximity to power during the course of his life gave him a start that Nixon certainly never had. So how did his behaviour and decision-making up to and during the 2000 campaign reflect the authenticity of his character?

Barber provides the criterion of 'orientation toward life in an enduring way'. Gore emerges against that framework as someone who seemed ultimately unsure of himself. He struggled to be his own person and at the two crucial stages of his career he could 
not escape the shadow of, firstly, his father and then of Clinton. He was, unlike Bush, unsure of how to separate himself from the two of them while at the same time maintaining links useful to advancing his career.

The models offered by Barber to determine presidential style and character are more difficult to align with Gore. Barber's 'passive-positive' model resonates with certain aspects of Gore's character traits and can be summarised as a

“... receptive, compliant, other-directed character ... search[ing] for affection as a reward for being agreeable ... rather than personally assertive ... [t]heir dependence and the fragility of their hopes ... make disappointment in politics likely." 356

Gore, at times, failed to give the impression he enjoyed what he did and during the 2000 campaign he appeared detached from the process, particularly during the first televised debate. To say he appeared "other-directed" is probably overstating the position, but he did appear unsure of how he should present, prompting one author in particular to refer to the "four faces of Al Gore" 357 that emerged during the campaign. The mode of operation adopted by Gore during the post-election court hearing processes seemed to heighten the inevitability of defeat, as Gore seemed unsure of how to capitalise on his popular vote victory to convey the impression of being the heir apparent.

The other relevant model offered by Barber is that of 'passive-negative'. Under this framework the candidates'

“... [character is rooted in an orientation] toward doing dutiful service; this compensates for low self-esteem based on a sense of uselessness. [They] are in politics because they think they ought to be ... [t] heir tendency is to withdraw, to escape from the conflict and uncertainty of politics by emphasising vague principles ..." 358

While this model does not directly encapsulate the Gore character, aspects of it resonate. It is the sense of uncertainty of knowing oneself that aligns to this model. Gore's shifting style reflects a notion of vague principles; the mannerisms he displayed

\footnotetext{
356 Barber, The Presidential Character, p. 13.

${ }^{357}$ Ceaser and Busch, The Perfect Tie, p. 109.

358 Barber, The Presidential Character, p. 13.
} 
during the first televised debate gave the impression he thought himself slightly reduced by the campaign. Yet the real political experience Gore had by the 2000 campaign was significant, and theoretically he was extremely well prepared for presidential office.

Under the Gardner model, Gore meets the stamina and competence tests as he had been an elected representative and Vice President for eight years. He had a need to achieve and the capacity to manage, assert and dominate. His vice presidency meant he was often 'in the room' when decisions were made; he undertook key policy drives in the administration and was considered to be extremely disciplined during Clinton's two presidential campaigns. All these elements of the Gardner model were met by Gore in outlining his character construct.

Gore also meets the two crucial elements of motive and resource in the Burns model. Gore was certainly motivated, having decided to run in 1992 after initially indicating he would not. He had previously offered himself as a presidential candidate and had served his apprenticeship under Clinton. He represented the new era of Democrats and had a history of electoral success. Gore had the backing of the traditional Democratic Party machine so did not lack resource. Being a sitting Vice President also put enormous resources at his disposal, just as it had for Nixon forty years earlier.

Temperament is emphasised by Neustadt as a guide to character and leadership potential, and in this regard the performance of Gore, particularly during the televised debates, was lacking. He seemed frustrated by the process, possibly squandering the undoubted advantage he held leading into the debates. Further, his change of style during the three debates led to the view that it was difficult to know who the 'real' Gore was. In short, Gore did not come across as at ease with either the campaign process or himself. His authenticity was compromised at precisely the time Bush appeared steady and predictable. 
Tellingly, Gore also finds some difficulty when applying the Hargrove criteria to his character traits. Gore has no difficulty in meeting the requirements for skill - he was bright and experienced - but when it came to cultural leadership and the generational shift that he had achieved with Clinton, Gore was reluctant to capitalise on those positive achievements. Integrity was also compromised. The exaggeration effect of some of the claims Gore made during the campaign meant Bush was able to capitalise on trust, while Gore, regardless of his inherent honesty, looked like he was someone controlled by focus groups rather than a person with a defined inner core or compass.

The clarity of Gore's teaching reality was also confused. Did he represent a continuation of the good economic times, and if so where was Clinton in this campaign? If he was striking out on his own, how was what he offered any different to what the country had become accustomed to when he was Vice President? An emphasis on 'higher moral standards' was not enough to re-elect him as President. In trying to match the moderate Bush, Gore allowed the race to become about personality rather than a discussion about "the quality of political discourse in the polity." 359 By not competing at a policy level, the contest became about which candidate was not only more believable, but which candidate was easier to like.

The authentic Gore was missing, as emphasised in Renshon's model. Gore meets the ambition element for reasons already addressed, but as noted, there remained residual issues regarding integrity. That may not have mattered so much if Gore had presented a definitive teaching reality. If Gore had advanced the issue of the environment in the way he has done since leaving politics, its impact may have been significant. It seems, to use the Renshon model more fully, that "[Gore] may have developed and redefined his ... ideals and values but lack[ed] the capacity to realize them in a manner that maintain[ed] fidelity to them." 360

\footnotetext{
${ }^{359}$ Hargrove, The President as Leader, p. 42.

${ }^{360}$ Renshon, The Psychological Assessment of Presidential Candidates, p. 188.
} 
As the campaign evolved, it became increasingly difficult to seek out and understand 'core Gore'. Importantly, he had exhibited the capacity to endure loss (the death of his sister and the accident involving his son), meaning he could withstand conflict, both personal and public, as would be required as President. The most compelling aspect of the Gore character is that it was at these exact moments of personal hardship that the genuine and real Gore emerged and some of his most powerful and persuasive qualities were revealed.

As to the matter of relatedness, Gore encouraged a collegial style around him but would react if he felt he was being too closely handled; a family man, Gore seemed to rely on his wife and family to maintain balance and purpose. His need to morph into his surroundings revealed a lack of inner sureness and his inability to transform the popular vote win into a tide for Gore claiming the presidency indicated a lack of understanding in respect of the relatedness element of the Renshon model with the public at large. ${ }^{361}$

Renshon's character-style framework provides the final analytical measure. Gore certainly exhibited the cognitive capacity to do the job of President. He was studious, with well-practiced interpersonal skills, and he did not divide the polity during the 2000 campaign (neither did Bush); however, he lacked the intense calmness that candidates need to show when under pressure, perhaps reflecting his lack of inner selfconfidence.

Gore certainly displayed authenticity many times during his life; his reaction to the death of his sister and his writing when his son was badly injured all point to someone of depth and conviction. The way Gore has championed issues since leaving politics indicate a person who has found himself and his core values. But the dutiful son, desperate to keep up with his father as they bounded through the corridors of Washington, was the same man desperate to climb from behind the shadow of Clinton

\footnotetext{
361 The 2016 election, in which Hillary Clinton won the popular vote, but lost the presidency, also raises questions about character, and authenticity, particularly in respect of her response (over several years) to the outcome - an area for further research building on the themes and academic literature explored in this thesis.
} 
years later. Not knowing whether to distance himself from his father or leverage off him in his first campaign was the same dilemma faced in 2000 with the former president. Gore simply seemed unable to make up his mind.

It was the period between the Election Day stalemate - the events of a concession and then a retraction of it - and the final Supreme Court decision that was the most revealing. Gore seemed unable to look Presidential while serving as Vice President. At this point he made the crucial decision to continue to fight for the White House through the courts - insisting on recounts and reacting to the legal actions being brought by the Bush camp. Perhaps Gore did not believe he would have another chance to run or that the popular vote victory he had secured meant he had no choice but to continue to fight. In any event, his behaviour post-election could be regarded as situationally authentic. He fought to right a wrong - the perceived inaccuracy of the Florida vote count - and agitated to the end, but ultimately did not challenge the Supreme Court ruling; in essence “... Gore's decision not to fight the Supreme Court's ruling in Bush v. Gore allowed for a peaceful resolution of the election, and not a single Democratic senator objected ...".362 Significantly, the traits he displayed as Vice President when he had to preside over Congress, reading out the Electoral College votes (including Florida) - affirming both Bush's win and his own defeat - signalled the emergence of someone who was well down the path to "... know[ing], accept[ing], and remain[ing] true to one's self." 363 To conclude whether Gore was authentic at this point, or not, is vexing as "... the line between real and authentic gets harder to discern. With Gore, it varies from moment to moment." 364 Ceaser and Busch outline

\footnotetext{
${ }^{362}$ Greenfield, Jeff. (2019). How the 2020 Election Could Go Off the Rails in Three Easy Steps. Politico Magazine: https://www.politico.com/magazine/story/2019/05/13/2020-election-contested-donaldtrump-226869, p. 4.

${ }^{363}$ Aviolio et al., Unlocking the Mask, p. 802.

364 Cooper, Matthew. (1999). The Search for Authenticity. www.cnn.com/ALLPOLITICS/time/ 1999/10/25/view.html.
} 
Gore's "five stopping points" along the pathway to his concession, noting it was only at the last "stopping point" that he stepped back. ${ }^{365}$

Gore's character remains difficult to define and enduring authenticity remains elusive. For Gore, while authenticity did not exist as an "... either/or condition ..."366 he did move further toward the authentic end of the Aviolio continuum ${ }^{367}$ once the Supreme Court made its decision. His final response to the court's ruling saw his own authenticity further crystallise, and he emerged from the shadow of both his father and Clinton. His subsequent advocacy of environmental concerns confirms someone who has found a version of themselves that can endure. Gore's behaviour at the last "stopping point" indicates the appearance of character traits applied with consistency to his decision-making, revealing a more authentic character than had previously been apparent. Perhaps it took the 2000 election, and its contentious outcome, to allow that Gore to be revealed.

\footnotetext{
365 Ceaser and Busch, The Perfect Tie, pp. 203-210. A section titled 'An Appraisal of Constitutional Statesmanship' outlines the five stopping points.

${ }^{366}$ Aviolio et al., Authentic Leadership Development, p. 320.

${ }^{367}$ Aviolio et al., Unlocking the Mask, p. 802.
} 


\section{CHAPTER NINE:}

\section{CONCLUDING COMPARISONS: TWO ELECTIONS, FOUR CANDIDATES AND THE IMPORTANCE OF 'AUTHENTICITY'.}

This concluding chapter contrasts the 1960 and 2000 elections, focusing on the role of incumbent Presidents in each campaign and the differing levels of authenticity each of the candidates displayed with respect to the election result. Both elections involve a comparable dilemma: how best to utilise a sitting President in an electoral contest particularly when one of the candidates is Vice President. In both elections it was the Vice President who lost, suggesting that the strategies employed were ultimately not effective.

In 1960, Nixon's choice not to immediately invite Eisenhower into the contest was fundamentally flawed. Eisenhower had left office with his popularity intact and had proven himself above party politics, but Nixon's fear of being seen to ride on Eisenhower's coattails and the effect this may have had on his image of "manhood" resulted in a misplaced strategy. Gore's situation was different and the risks much greater. In considering Clinton's potential involvement, Gore had to make a deliberate trade-off: weighing Clinton's behaviour against the economic success of his last years in office, a legitimate consideration.

No such real or imagined issues existed for Nixon when considering employing Eisenhower's influence. Nixon had nothing to lose from allowing Eisenhower to engage with voters. In leaving that engagement until the last moment, Nixon ran the risk of making it appear as though he needed Eisenhower's support to win, and it also made Eisenhower's eventual involvement appear less than fulsome. Similarly, Gore would have been more likely to win in 2000 had Clinton campaigned for him. But Gore's likely success was less certain than Nixon's. Nixon had none of the baggage 
that Gore was carrying, and his chances of winning in 1960 would have been enhanced had Eisenhower campaigned throughout the election.

A more complex matter involves the comparison of the candidates' authentic character traits and the effect that may have had on the outcome of the elections. The candidates who won the election, becoming President, met an authentic character test. Both Kennedy and Bush exhibited the character traits required to meet the criteria set out in the theoretical frameworks outlined in chapter 2. Instructively, politicians seeking high office need a core, encompassing a set of traits that are present throughout their lives, in differing situations. Although people can change, develop and mature over time, it seems clear that the more fundamental that core, the more likely that decision-making will occur in a way consistent with those underlying beliefs and traits.

To be flexible in approach does not necessarily mean abandoning genuine values, but rather using them as a compass to shape behaviour and responses over a significant period of time: importantly, the authentic nature of the contender's character must be enduring. More than that, the voting public need to know that the background, upbringing and pre-political life of the candidate is being consistently exhibited with this enduring set of traits and that it acts as a basis for the contender's behaviour. Erratic, ever changing viewpoints, positions and attitudes are seen for what they are by the voter: trying to be all things to all people. This particular approach to politics and elections has sometimes been described as "triangulation," but this framework is about policy positioning, and not the authentic nature of the candidate seeking office. If the two blur during the electoral process, an appearance of lacking substance can quickly move from the triangulated policy position to the candidates themselves.

As Gore moved along the continuum of authenticity he confronted difficulty. When commentators refer to "The Four Faces of Al Gore" they address an issue with the type of image that the candidate is projecting, asking, 'does this individual have something to hide?' That response, raising a question of trust, can be fatal in a campaign. ${ }^{368}$

\footnotetext{
368 Ceaser and Busch, The Perfect Tie, p. 109.
} 
Over a longer political career this may prove to be only a short-term issue for the candidate: Nixon was twice elected President following his defeat in 1960, testament to his grit and determination. When this Nixon emerged, he was elected on his own merits, more genuine than he had been in 1960: unthreatened, more sure of himself, the authentic Nixon. Timing is an unavoidable factor in politics, and 1960 was looking for generational change in leadership, which was not represented by Nixon given his position as Vice President.

Bush spent his life forming his image in the way he saw himself and wanted others to see him. Like Kennedy, Bush was at ease with himself and his own limitations and weaknesses. The public recognised the authenticity that they saw in him. Although he softened some of his policy stances to appeal to moderate and independent voters, Bush remained essentially unchanged from his younger days. His demeanour and approach were consistent and the public felt that they understood what type of president he would be. The same could not be said for Gore.

Since the 2000 election Gore has shown what a skilled advocate he can be. Encapsulating a cause he feels strongly about has allowed him to rise above the clamour of politics to be among the most successful advocates for climate change policies. It is interesting to hypothesise how the 2000 campaign might have been had Gore promoted the environment as a key feature of his election strategy.

Of the four candidates this thesis has examined, three ultimately became President of the United States. There are things they had in common, in particular the desire to lead. All had experienced death: each had lost a sibling when they were younger. The differences between them also were stark.

While Kennedy, Bush and (to an extent) Gore enjoyed lives of privilege and access to influence, Nixon had not, making his political ascent all the more remarkable. Bush and Kennedy enjoyed a natural ease - sometimes described in Kennedy's case as 
"grace under pressure" - whereas Gore and Nixon often displayed awkwardness, embarrassing themselves and their supporters. The candidates who displayed consistent authenticity in their decision-making, and in their reaction to less than clearcut election results, were successful. Bush and Kennedy presented their credentials in a meaningful and consistent way, conducting themselves in ways that voters understood and appreciated.

Ultimately, authenticity can assist in delivering the Presidency to those who seek it and remain self aware in a way that allows the public to see them exhibiting their 'real selves' on the campaign trail. 


\section{BIBLIOGRAPHY}

\section{Books}

Ambrose, Stephen E. (1987). Nixon: Volume One: The Education of a Politician, 1913-1962. New York: Simon \& Schuster.

Barber, James D. (1972). The Presidential Character - Predicting Performance in the White House. New Jersey: Prentice Hall.

Barber, James D. (1992). The Presidential Character - Predicting Performance in the White House (fourth edn.). New Jersey: Prentice Hall.

Bennis, Warren. (2003). On Becoming a Leader. New York: Basic Books.

Berecz, John M. (2001). Character in Chief: The Personality and Character of George W. Bush and Past Presidents. Atlanta: Humanics Publishing.

Boller, Paul F. Jr. (1996). Presidential Campaigns. New York: Oxford University Press.

Bossie, David N and Brown, Floyd G. (2000). Prince Albert: The Life and Lies of Al Gore. Washington: Merril Press.

Buchanan, Patrick J. (2014). The Greatest Comeback: How Richard Nixon Rose from Defeat to Create the New Majority. New York: Crown Publishing.

Burns, James MacGregor. (1978). Leadership. New York: Harper \& Row.

Ceaser, James W. and Busch, Andrew E. (2001). The Perfect Tie: The True Story of the 2000 Presidential Election. Lanham, Maryland: Rowman and Littlefield.

Cockburn, Alexander and St Clair, Jeffrey. (2000). Al Gore: A User's Manual. New York: Verso.

Critchlow, Donald T. (2018). Republican Character: From Nixon to Reagan. Philadelphia, Pennsylvania: University of Pennsylvania Press. 
Dallek, Robert. (2003). An Unfinished Life: John F. Kennedy 1917-1963. New York: Little, Brown.

Dionne, E. J. Jr and Kristol, William (eds.). (2001). Bush vs. Gore: The Court Cases and the Commentary. Washington, D.C: Brookings Institution Press.

Donaldson, Gary A. (2007). The First Modern Campaign: Kennedy, Nixon, and the Election of 1960. Maryland: Rowman \& Littlefield.

Farrell, John A. (2017). Richard Nixon - The Life. New York: Vintage Books.

Ferejohn, John A. \& Kuklinski, James H. (eds.). (1990). Information and Democratic Processes. Chicago: University of Illinois Press.

Foley, Edward, B. (2016). Ballot Battles - The History of Disputed Elections in the United States. New York: Oxford University Press.

Frum, David. (2003). The Right Man - The Surprise Presidency of George W. Bush. New York: Random House.

Gadney, Reg. (1983). Kennedy. London: Macdonald.

Gardner, John W. (1990). On Leadership. New York: The Free Press.

Gellman, Irwin F. (1999). The Contender - Richard Nixon: The Congress Years. New York: The Free Press.

Gergen, David. (2000). Eyewitness to Power: The Essence of Leadership - Nixon to Clinton. New York: Simon \& Schuster.

Giglio, James N. (1991). The Presidency of John F. Kennedy. Kansas: University Press of Kansas.

Gillman, Howard. (2001). The Votes that Counted: How the Court decided the 2000 Presidential Election. Chicago: University of Chicago Press. 
Greenberg, David. (2003). Nixon's Shadow - This History of An Image. New York: W.W. Norton.

Greenstein, Fred I. (2000). The Presidential Difference: Leadership Style from FDR to Clinton. New York: The Free Press.

Hamilton, Nigel. (2010). American Caesars. Lives of the Presidents from Franklin D. Roosevelt to George W. Bush. New Haven: Yale University Press.

Hamilton, Nigel. (1992). JFK - Reckless Youth. London: Random House.

Hargrove, Erwin C. (1998). The President as Leader - Appealing to the Better Angels of Our Nature. Kansas: University Press of Kansas.

Hargrove, Erwin C. and Owens, John E. (eds.). (2003). Leadership in Context. Lanham, Maryland: Rowman \& Littlefield.

Hatfield, James. (2002). Fortunate Son - George W. Bush and the Making of an American President. London: Vision.

Holian, David B. and Prysby, Charles L. (2015). Candidate Character Traits in Presidential Elections. New York: Routledge.

Ivins, Molly and Dubose, Lou. (2000). Shrub - The Short But Happy Political Life of George W. Bush. New York: Random House.

Jeffrey, Laura S. (1999). Al Gore: Leader for the New Millennium. New Jersey: Enslaw Publishers.

Johansson, Jon. (2002). Political Leadership in New Zealand: Theory \& Practice. Wellington: Victoria University of Wellington.

Kallina, Edmund F. Jr. (2010). Kennedy v. Nixon - The Presidential Election of 1960. Gainesville, Florida: University Press of Florida.

Kessler, Ronald. (1996). The Sins of the Father - Joseph P. Kennedy and the Dynasty He Founded. London: Hodder and Stoughton. 
King, Anthony (ed.). (2002). Leaders' Personalities and the Outcomes of Democratic Elections. New York: Oxford University Press.

Klein, Joe. (2002). The Natural: The Misunderstood Presidency of Bill Clinton. New York: Doubleday.

Liebovich, Louis W. (1998). The Press and the Modern Presidency: Myths and Mindsets, from Kennedy to Clinton. Westport, Connecticut: Praeger.

Lind, Michael. (2003). Made in Texas - George W. Bush and the Southern Takeover of American Politics. New York: Basic Books.

Ling, Peter J. (2013). John F. Kennedy. New York: Routledge.

McDonald, Forrest. (1994). The American Presidency - An Intellectual History. Kansas: University Press of Kansas.

McPherson, James M. (ed.). (2000). "To the Best of My Ability" - The American Presidents. New York: Dorling Kindersley Publishing.

Mahoney, Richard D. (1999). Sons and Brothers: The Days of Jack and Bobby Kennedy. New York: Arcade Publishing.

Maier, Thomas. (2003). The Kennedys: America's Emerald Kings. New York: Basic Books.

Mann, James. (2015). George W. Bush. New York: Times Books.

Mason, Robert. (2004). Richard Nixon and the Quest for a New Majority. Chapel Hill: University of North Carolina Press.

Matthews, Christopher. (1996). Kennedy \& Nixon - The Rivalry that Shaped Postwar America. New York: Simon \& Schuster.

Milbank, Dana. (2001). Smashmouth - Two Years in the Gutter With Al Gore and George W. Bush - Notes from the 2000 Campaign Trail. New York: Basic Books. 
Miller, Warren E. and Shanks, J Merrill. (1996). The New American Voter. Massachusetts: Harvard University Press.

Minutaglio, Bill. (1999). First Son - George W. Bush and the Bush Family Dynasty. New York: Random House.

Moore, James and Slater, Wayne. (2003). Bush's Brain - How Karl Rove made George W. Bush Presidential. New Jersey: John Wiley \& Sons.

Moraniss, David and Nakashima, Ellen. (2000). The Prince of Tennessee: The Rise of Al Gore. New York: Simon \& Schuster.

Nelson, Michael. (ed.). (2018). The Presidency and the Political System. Los Angeles: Sage/CQ Press.

Neustadt, Richard E. (1960). Presidential Power - The Politics of Leadership. New York: John Wiley.

Neustadt, Richard E. (1990). Presidential Power and the Modern Presidents: The Politics of Leadership from Roosevelt to Reagan. New York: The Free Press.

Nimmo, D. and Savage, Robert L. (1976). Candidates and Their Images - Concepts, Methods and Findings. Santa Monica, California: Goodyear.

Oliphant, Thomas and Wilkie, Curtis. (2017). The Road to Camelot - Inside JFK's five-year Campaign. New York: Simon \& Schuster.

Perret, Geoffrey. (2001). Jack - A Life Like No Other. New York: Random House.

Pfiffner, James P. (2004). The Character Factor: How We Judge America's Presidents. Texas: A\&M University Press, Texas.

Phillips, Kevin. (2004). American Dynasty. New York: Penguin.

Phillips, Kevin, P. (1970). The Emerging Republican Majority. New York: Doubleday. 
Pietrusza, David. (2008). 1960: LBJ vs. JFK vs. Nixon. The Epic Campaign that Forged Three Presidencies. New York: Diversion Books.

Popkin, Samuel L. (1991) The Reasoning Voter - Communication and Persuasion in Presidential Campaigns. Chicago: The University of Chicago Press.

Reeves, Richard. (1993). President Kennedy - Profile of Power. New York: Simon \& Schuster.

Reeves, Richard. (2001). President Nixon - Alone in the White House. New York: Simon \& Schuster.

Reeves, Thomas C. (1991). A Question of Character - A Life of John F. Kennedy. London: Bloomsbury.

Renshon, Stanley A. (1998). The Psychological Assessment of Presidential Candidates. New York: New York University Press.

Rorabaugh, W J. (2009). The Real Making of the President: Kennedy, Nixon, and the 1960 Election. Kansas: University Press of Kansas.

Rubin, Gretchen. (2005). Forty Ways to Look at JFK. New York: Random House.

Saunders, Debra J. (2000). The World According to Gore. San Francisco: Encounter Books.

Schlesinger, Arthur M. Jr. (1965). A Thousand Days - John F. Kennedy in the White House. London: Andre Deutsch.

Shaw, John T. (2013). JFK in the Senate. Pathway to the Presidency. New York: Palgrave.

Singer, Peter. (2004). The President of Good and Evil: The Ethics of George W. Bush. Melbourne: The Text Publishing Company.

Stefoff, Rebecca. (1999). Al Gore: Vice President: A Gateway Biography. Brookfield, Connecticut: Millbrook Press. 
Summers, Anthony. (2000). The Arrogance of Power - The Secret World of Richard Nixon. London: Victor Gollancz.

Sunstein, Cass R. and Epstein, Richard A. (eds.). (2001). The Vote: Bush, Gore and the Supreme Court. Chicago: University of Chicago Press.

Thomas, Evan. (2015). Being Nixon - A Man Divided. New York: Random House.

Turque, Bill. (2000). Inventing Al Gore: A Biography. New York: Houghton Mifflin.

Wattenberg, Martin P. (1991). The Rise of Candidate-Centred Politics: Presidential Elections of the 1980s. Cambridge, Massachusetts: Harvard University Press.

Wilson, Robert A. (ed.). (1995). Character Above All - Ten Presidents from FDR to George Bush. New York: Simon \& Schuster.

Zelnick, Bob. (1999). Gore: A Political Life. Washington, D.C: Regnery Publishing.

\section{Articles/Chapters}

Anand, Sowmya and Krosnick, Jon A. (2003). The Impact of Attitudes Toward Foreign Policy Goals on Public Preferences Among Presidential Candidates: A Study of Issue Publics and the Attentive Public in the 2000 US Presidential Election. Presidential Studies Quarterly, 33(1), pp. 31-71.

Avolio, Bruce J., Gardner, William L., Walumbwa, Fred O., Luthans, Fred and May, Douglas R. (2004). Unlocking the mask: A look at the process by which authentic leaders impact follower attitudes and behaviors. The Leadership Quarterly, 15, pp. 801-823.

Avolio, Bruce J. and Gardner, William L. (2005). Authentic leadership development: Getting to the root of positive forms of leadership. The Leadership Quarterly, 16, pp. 315-338.

Bass, Bernard M. and Steidlmeier Paul. (1999). Ethics, Character, and Authentic Transformational Leadership Behavior. Leadership Quarterly, 10(2), pp. 181-217. 
Bhindi, Narottam and Duignan. (1997). Leadership for a New Century. Authenticity, Intentionality, Spirituality and Sensibility. Education Management \& Administration, 25(2), pp. 117-132.

Bishin, Benjamin G., Stevens, Daniel and Wilson, Christian. (2006). Character Counts: Honesty and Fairness in Election 2000. Public Opinion Quarterly, 70(2), pp. 235-248.

Campbell, James E. (1983). Candidate Image Evaluations. Influence and Rationalization in Presidential Primaries. American Politics Quarterly. 11(3), pp. 293-313.

Coenen, Craig R. (2003). The Election of 1960. In William G. Shade \& Ballard C. Campbell (eds.), American Presidential Campaigns and Elections. New York: M.E. Sharpe, pp. 849-866.

Cooper, Matthew. (1999). The Search for Authenticity. www.cnn.com/ALLPOLITICS/ time/1999/10/25/view.html.

Conley, Richard S. (2002). Too Close to Call: The Thirty-Six Day Battle to Decide the 2000 Election. Presidential Studies Quarterly, 32(3), pp. 615-617.

Conover, Pamela J. (1981). Political Cues and the Perception of Candidates. American Politics Quarterly, 9(4), pp. 427-448.

Dudley, Robert L. (2001). The Contemporary Presidency: The Presidential Election of 2000: A Great Civics Lesson? Presidential Studies Quarterly, 31(3), pp. 505-513.

Edwards, Lee. (2001). The Closest Presidential Election Ever - Bush Won, Barely, by Offering a Slightly to the Right, Limited-Government Presidency. World and I, 16(2), pp. 20-27.

Ellsworth, John W. (1965). Rationality and Campaigning: A Content Analysis of the 1960 Presidential Campaign Debates. Western Political Quarterly, 18(4), pp. 794-802.

Erikson, Robert S. (2001). The 2000 Presidential Election in Historical Perspective. Political Science Quarterly,16(1), pp. 29-52. 
Felkins, Patricia K. and Goldman, Irvin. (1993). Political Myth as Subjective Narrative: Some Interpretations and Understandings of John F. Kennedy. Political Psychology, 14(3), pp. 447-467.

Fiorina, Morris, Abrams, Samuel and Pope, Jeremy. (2003). The 2000 US Presidential Election: Can Retrospective Voting Be Saved? British Journal of Political Science, 33(2), pp. 163-187.

Fitzpatrick, Gerard J. (2002). Bush v. Gore: Popular Sovereignty, Fundamental Law, and the Post-Election Battle for the Presidency. Polity, 35(1), pp. 153-168.

Franck, Matthew J. (2003). Election 2000 Revisited. Presidential Studies Quarterly, 33(1), pp. 238-242.

Funk, Carolyn L. (1999). Bringing the Candidate into Models of Candidate Evaluation. The Journal of Politics, 61(3), pp. 700-720.

Gibson, James L, Caldeira, Gregory A. and Spence, Lester K. (2003). The Supreme Court and the US Presidential Election of 2000: Wounds, Self-Inflicted or Otherwise? British Journal of Political Science, 33(4), No. 4, pp. 535-556.

Goren, Paul. (2007). Character Weakness, Partisan Bias, and Presidential Evaluation: Modifications and Extensions. Political Behaviour, 29(3), pp. 305-325.

Graber, Mark A. (2002). Supreme Injustice: How the High Court Hijacked Election 2000 \& The Votes that Counted: How the Court Decided the 2000 Presidential Election. Political Science Quarterly, 117(4), pp. 674-677.

Greenberg, David. (2000). Was Nixon Robbed? The Legend of the Stolen 1960 Presidential Election. Slate, 16 October.

Greene, Steven. (2001). The Role of Character Assessments in Presidential Approval. American Politics Research, 29(2), pp. 196-210. 
Greenfield, Jeff. (2019). How the 2020 Election Could Go Off the Rails in Three Easy Steps. Politico Magazine: https:/www.politico.com/magazine/story/2019/05/13/2020election-contested-donald-trump-226869.

Hale, Dennis. (2002). America's Choice 2000: Entering a New Millennium \& The Perfect Tie: The True Story of the 2000 Presidential Election. Political Science Quarterly, 117(1), pp. 127-130.

Hargrove, Erwin C. (2001). Presidential Power and Political Science. Presidential Studies Quarterly, 31(2). pp. 245-261.

Hayes, Danny. (2005). Candidate Qualities through a Partisan Lens: A Theory of Trait Ownership. American Journal of Political Science, 49(4), pp. 908-923.

Hickey, Neil. (2001). The Big Mistake. Columbia Journalism Review, 39(5), pp. $32-35$.

Kennedy, Fiona and Kolb, Darl G. (2016). The Alchemy of Authenticity: Lessons from the 2016 US Presidential Campaign. Organizational Dynamics, 45, pp. 316-322.

Kilburn, H. Whitt. (2005). Does the Candidate Really Matter? American Politics Research, 33(3), pp. 335-356.

Kinder, Donald R. (1986). Presidential Character Revisited, in Lau, Richard R. and Sears, David O. (eds.), Political Cognition. New Jersey: Lawrence Erlbaum.

Koring, Paul. (2000). U.S. Election: It Was Close, All Right. Bell Globemedia Interactive.

Kowert, Paul A. (1996). Where Does the Buck Stop?: Assessing the Impact of Presidential Personality. Political Psychology, 17(3), pp. 421-452.

Lemann, Nicholas. (2000). Gore Without A Script - What Would Happen If We Saw The Man He Really Is? The New Yorker, 31 July, pp. 44-60. 
Markus, Gregory B. (1982). Political Attitudes during an Election Year: A Report on the 1980 NES Panel Study. The American Political Science Review, 76(3). pp. 538-560.

May, Douglas R., Chan, Adrian Y.L., Hodges, Timothy D. and Avolio, Bruce J. (2003). Developing the Moral Component of Authentic Leadership. Organizational Dynamics, 32(3), pp. 247-260.

Miller, Arthur H., Wattenburg Martin P. and Malanchuk, Oksana. (1986). Schematic Assessments of Presidential Candidates. American Political Science Review, 80(2), pp. $521-540$.

Miller, Arthur H. and Klobucar, Thomas F. (2003). The Role of Issues in the 2000 Presidential Election. Presidential Studies Quarterly, 33(1), pp. 101-124.

Pomper, Gerald M. (2002). Missed Opportunity: Gore, Incumbency, and Television in Election 2000. Political Science Quarterly, 117(3), pp. 529-531.

Pomper, Gerald M. (2001). The 2000 Presidential Election: Why Gore Lost. Political Science Quarterly, 116(2), pp. 201-223.

Renshon, Stanley A. (2000). Political Leadership as Social Capital: Governing in a Divided National Culture. Political Psychology, 21(1), pp. 199-226.

Self, John W. (2005). The First Debate Over the Debates: How Kennedy and Nixon Negotiated the 1960 Presidential Debates. Presidential Studies Quarterly, 35(2), pp. 361-375.

Shamir, Boas and Eilam, Galit. (2005). "What's your story?” A life-stories approach to authentic leadership development. The Leadership Quarterly, 16, pp. 395-417.

Stewart, Marianne C. and Clarke, Harold D. (1992). The (Un)Importance of Party Leaders: Leader Images and Party Choice in the 1987 British Election. The Journal of Politics, 54(2), pp. 447-470. 
Waldman, Paul and Hall Jamieson, Kathleen. (2003). Rhetorical Convergence and Issue Knowledge in the 2000 Presidential Election. Presidential Studies Quarterly, 33(1), pp. 145-163.

Weiss, Melanie S. (2003). The Election of 2000. In William G. Shade and Ballard, C. Campbell (eds.), American Presidential Campaigns and Elections. New York: M. E. Sharpe, pp. 1032-1054.

Winter, David G. (2005). Things I've Learned About Personality From Studying Political Leaders at a Distance. Journal of Personality, 73(3), pp. 557-584. 